\title{
Caracterização microbiana e remoção do alquilbenzeno linear sulfonado em reator EGSB
}

\author{
Dissertação apresentada à Escola de \\ Engenharia de São Carlos da Universidade de \\ São Paulo para obtenção do título de Mestre \\ em Ciências da Engenharia Hidráulica e \\ Saneamento
}

Orientadora: Profa. Dra. Maria Bernadete Amâncio Varesche

Versão Corrigida

Abril

2011 
AUTORIZO A REPRODUÇĀO E DIVULGAÇĀO TOTAL OU PARCIAL DESTE TRABALHO, POR QUALQUER MEIO CONVENCIONAL OU ELETRÔNICO, PARA FINS DE ESTUDO E PESQUISA, DESDE QUE CITADA A FONTE.

Ficha catalográfica preparada pela Seção de Tratamento da Informação do Serviço de Biblioteca - EESC/USP

D351c

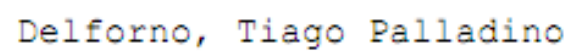

Caracterizaçăo microbiana e remoçăo do alquilbenzeno linear sulfonado em reator EGSB / Tiago Palladino Delforno ; orientadora Maria Bernadete Varesche. -- Săo Carlos, 2011.

Dissertaçăo (Mestrado-Programa de Pós-Graduação e Área de Concentração em Engenharia Hidráulica e Saneamento) -Escola de Engenharia de são Carlos da Universidade de Săo Paulo, 2011 .

1. Surfactantes. 2. Degradaçăo anaerobbia. 3. Gene RNAr 16s. 4. Técnica dos tubos múltiplos. 5. Biomassa granulada. 6. Bactérias redutoras de ferro. I. Título. 
FOLHA DE JULGAMENTO

Candidato(a): Bacharel TIAGO PALLADINO DELFORNO.

Dissertação defendida e julgada em 18.03.2011 perante a Comissão Julgadora:

Treareshe Oprovado Prof ${ }^{a}$. Dr ${ }^{a}$. MARIA BERNADETE AMANCIO VARESCHE SILVA (Orientadora)

(Escola de Engenharia de São Carlos/USP)

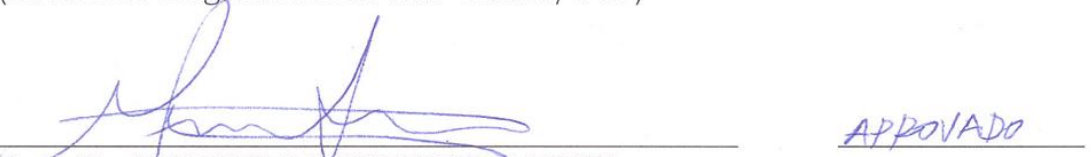

Prof. Dr. MARCELO LOUREIRO GARCIA

(Universidade Estadual Paulista "Júlio de Mesquita

Filho” / UNESP/campus de Rio Claro)

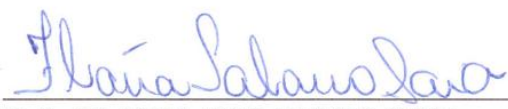

Dr ${ }^{a}$. FLAVIA TALARICO SAIA

(Pós-Doc/bolsa FAPESP)
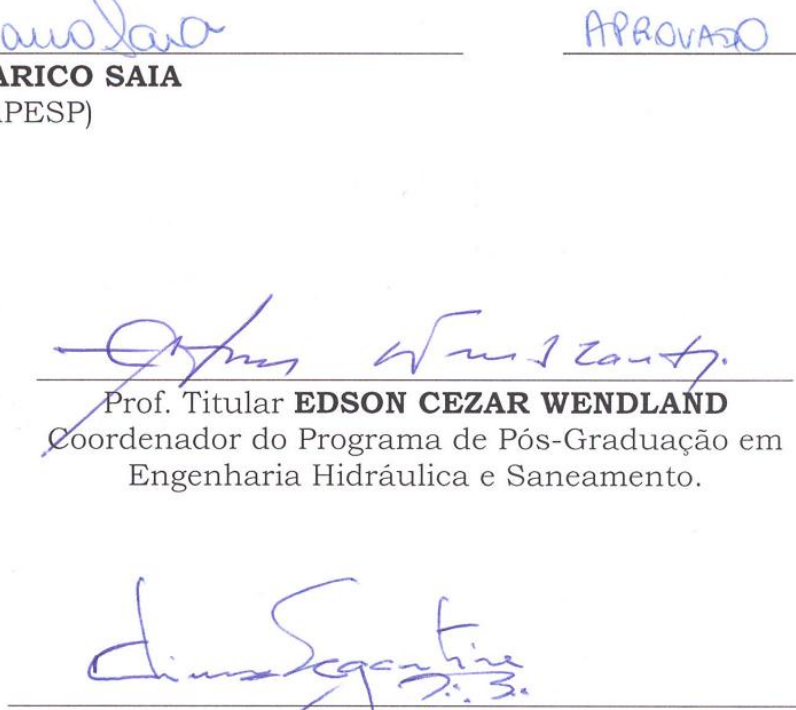

Prof. Associado/PAULO CÉSAR LIMA SEGANTINE

Presidente da Comissão da Pós-Graduação da EESC 
Aos meus pais Mauro e Rosa Minhas irmãs Juliana e Mariana Pelo amor e carinho Dedico. 


\section{AGRADECIMENTOS}

À Deus e Nossa Senhora das Graças.

À minha orientadora Profa. Dra. Maria Bernadete Varesche pelo apoio constante durante a realização desse trabalho, confiança e ensinamento profissional e pessoal.

Ao Professor Dr. Marcelo Zaiat e Dra. Isabel Sakamoto pelas valiosas sugestões na qualificação.

Aos amigos de turma e laboratório: Mariana Carosia, Daniel Fontes, Rafael Brito, Fabiana e Guilherme. Obrigado pelos momentos de descontração.

Ao doutorando e amigo Dagoberto Okada pela colaboração direta em todo o projeto e pela paciência em ensinar passo a passo a rotina no laboratório principalmente envolvendo a operação do reator.

À doutoranda e amiga Carolina Zampol pela ajuda nas questões envolvendo microbiologia e microscopia. Muito Obrigado.

À amiga Dr. Isabel Sakamoto pelos ensinamentos de Biologia Molecular.

À graduanda em Engenharia Ambiental, Juliana Polizel, pela ajuda constante.

A todos os freqüentadores/ex-frequentadores assíduos do Campus II e amigos de laboratório: Theo, Bruna, Gustavo, Guilherme, Jorge, Fabrício, Juliana, Lívia, Felipe, Mara, Regiane Correa, Regiane, Janja, Sandra, Flavia, Betão, Dú, Djalma, Tiago, Drica, Pilar e Júlia. Sou muito grato a todos vocês que de certa forma contribuíram para a realização desse trabalho, seja com sugestões, na rotina do laboratório ou em momentos de descontração (no boliche, karaokê, no almoço de domingo, jogando CS, na piscina ou jogando vôlei). Muito obrigado.

À Priscila Camiloti, pela paciência e carinho, minha admiração.

Ao técnico em informática Fernando pela ajuda na instalação dos softwares de bioinformática.

Ao Tiago Martins pelas sugestões envolvidas nas análises de Biologia Molecular.

Aos amigos de graduação Samantha Christina, Hugo Pereira e Aline Ramalho.

À Escola de Engenharia de São Carlos (USP), SHS, CNPQ e FAPESP pelo apoio.

Obrigado. 

"Os Professores abrem a porta, mas você precisa entrar sozinho" Provérbio Chinês. 



\section{RESUMO}

\section{DELFORNO, T. P. Caracterização Microbiana e Remoção do Alquilbenzeno}

Linear Sulfonado em Reator EGSB. 2011. 102F. Dissertação (Mestrado) - Escola de Engenharia de São Carlos, Universidade de São Paulo, São Carlos, 2011.

O presente trabalho teve por objetivo avaliar a eficiência de remoção do surfactante aniônico alquilbenzeno linear sulfonado (LAS) em reator anaeróbio de leito granular expandido - EGSB (1,5 litros) com recirculação e alimentação com meio mineral. Além de caracterizar filogeneticamente a diversidade de bactérias na presença do surfactante. O sistema foi operado em condição mesofílica em 4 etapas: (I), (II) e (IV) com TDH de 32 horas, e (III) com TDH de 26 horas. Em todas as etapas a DQO foi em média de $609 \pm 137 \mathrm{mg} / \mathrm{L}$ e $14 \pm 1,71 \mathrm{mg} / \mathrm{L}$ de LAS afluente. As maiores remoções de LAS foram

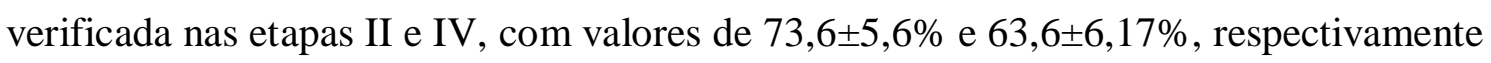
de. Na etapa III essa remoção foi de $47,8 \pm 6,2 \%$. Por meio do balanço de massa constatou-se que $56,6 \%$ do total de LAS adicionado foram removidos compreendendo $48,4 \%$ por biodegradação e $8,2 \%$ por adsorção. A remoção de matéria orgânica não foi afetada com a adição do LAS e nem pela exposição prolongada a esse surfactante. Entretanto, a estrutura do grânulo foi comprometida quando da adição do surfactante, observado pelo aumento da concentração de sólidos totais efluente de 0,049 g/L na etapa I (sem LAS), 0,128 g/L na etapa II, 0,064 g/L na etapa III e 0,038 g/L na etapa IV, quando da adição de $14 \pm 1,71 \mathrm{mg}$ LAS/L. Além disso, foi notada diminuição do diâmetro médio dos grânulos no decorrer da operação do reator de $0,36 \mathrm{~cm}$ nas etapas I e III para $0,34 \mathrm{~cm}$ na etapa IV. Por meio da técnica de tubos múltiplos (NMP) foi constatado aumento das bactérias anaeróbias totais e diminuição das arquéias metanogênicas, em função do tempo de operação do reator. As bactérias redutoras de ferro representaram $8 \%$ da biomassa anaeróbia na etapa IV. Por meio do seqüenciamento da região $16 \mathrm{~S}$ do RNAr para o domínio Bacteria da biomassa da extremidade superior do reator e da biomassa do leito, foi verificado semelhança com os seguintes filos Proteobacteria, Firmicutes e Synergistetes. Notou-se diferença significativa entre as bibliotecas de clones para essas duas amostras.

Palavras-chave: Surfactantes, degradação anaeróbia, gene RNAr 16S, técnica dos tubos múltiplos, biomassa granulada, bactérias redutoras de ferro 


\begin{abstract}
DELFORNO, T. P. Microbial Characterization and Removal of Linear Alkylbenzene Sulfonate in EGSB reactor. 2011. 102F. Dissertation (Master) - Escola de Engenharia de São Carlos, Universidade de São Paulo, São Carlos, 2011.

This study aimed to evaluate the efficiency of removal of linear alkylbenzene sulfonate (LAS) in expanded bed reactor (1.5 liters) using granular sludge (EGSB) with recirculation and feed with mineral medium modified. The system was operated at mesophilic condition in four stages: (I) (II) and (IV) with HRT of 32 hours, and (III) with HRT of 26 hours. At all stages the COD averaged $609 \pm 137 \mathrm{mg} / \mathrm{L}$ and $14 \pm 1.71 \mathrm{mg} / \mathrm{L}$ LAS influent. The higher removals of LAS were found in stages II and IV, respectively, $73.6 \pm 5.6 \%$ and $63.6 \pm 6.17 \%$. In stage III this removal was $47.8 \pm 6.2 \%$. Through mass balance was found that $56.6 \%$ of total LAS added were removed by biodegradation comprising $48.4 \%$ and $8.2 \%$ by adsorption. The organic matter removal was not affected by the addition of LAS and not by prolonged exposure to this surfactant. However, the granule structure was compromised after the addition of surfactant, the observed increase in effluent total solids concentration of $0.049 \mathrm{~g} / \mathrm{L}$ in stage I (no LAS), $0.128 \mathrm{~g} / \mathrm{L}$ in stage II, $0.064 \mathrm{~g} / \mathrm{L}$ in stage III and $0.038 \mathrm{~g} / \mathrm{L}$ in stage IV when adding $14 \pm 1.71 \mathrm{mg} / \mathrm{L}$. Furthermore, it was noticed significant decrease in mean diameter of the granules during the operation of the reactor of $0.36 \mathrm{~cm}$ in stages I and III to $0.34 \mathrm{~cm}$ in stage IV. Through the multiple tube method (MPN) was found to increase the total anaerobic bacteria and methanogenic archaea decreased depending on the time of reactor operation. Iron-reducing bacteria accounted for $8 \%$ of anaerobic bacteria total in step IV. By sequencing the 16S rRNA for the domain Bacteria biomass from the upper end of the reactor and the biomass of the bed, was found similar to the following phyla Proteobacteria, Firmicutes and Synergistetes. Significant difference was noted between the clone libraries for these two samples.
\end{abstract}

Keywords: Surfactants, anaerobic degradation, $16 \mathrm{~S}$ rRNA gene, multiple tubes technique, granulated biomass, iron-reducing bacteria 


\section{LISTA DE ILUSTRAÇÕES}

Figura 3.1: Estrutura do alquilbenzeno linear sulfonado .............................................. 5

Figura 3.2: Rota de degradação anaeróbia .................................................................. 10

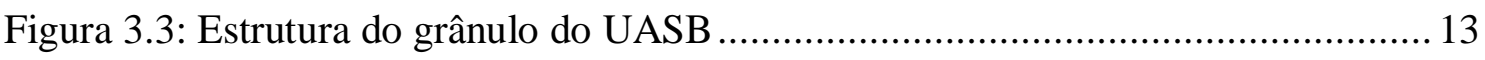

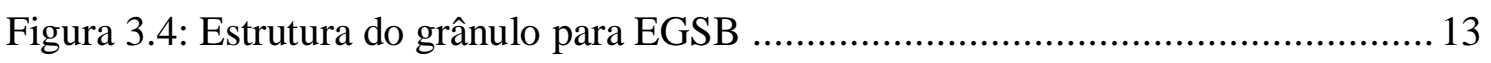

Figura 4.1: Fluxograma Experimental Geral...................................................... 15

Figura 4.2: Detalhes do reator EGSB. (A) esquema do reator, ................................ 16

Figura 4.3: Esquema do monitoramento da expansão do leito do reator EGSB ............22

Figura 4.4: Esquema da diluição seriada utilizando água de diluição e ........................ 27

Figura 4.5: Sequiência de passos até o seqüenciamento das amostras do reator..............29

Figura 5.1: Variação temporal da matéria orgânica..................................................... 36

Figura 5.2: Variação temporal da concentração de LAS afluente, efluente e remoção.. 38

Figura 5.3: Relação carga de LAS removida por carga de LAS aplicada...................... 39

Figura 5.4: Relação TDH e remoção de LAS........................................................... 41

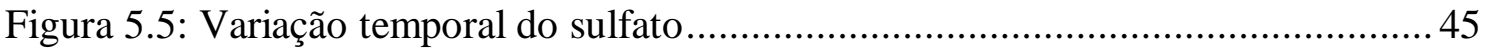

Figura 5.6: Variação temporal do sulfeto .................................................................. 46

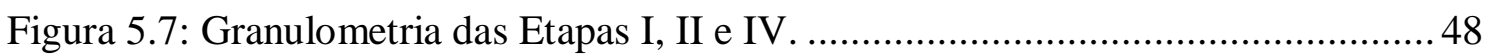

Figura 5.8: Variação temporal da remoção de LAS e s ácidos voláteis efluente ............51

Figura 5.9: Ensaio de anaerobiose do reator. (A) imagem do reator inteiro, (B) região superior do reator, (C) bomba de recirculação (cabeçote) e (D) ................................53

Figura 5.10: (A) Cromatograma típico de uma extração de LAS. (B) Cromatograma de

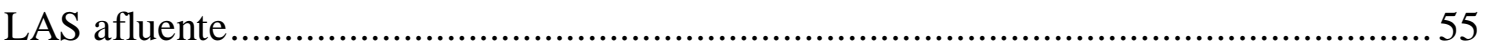

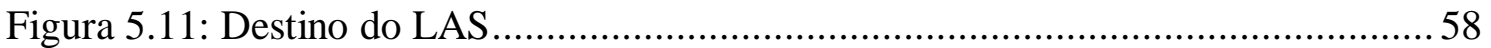

Figura 5.12: Proporção da adsorção do LAS no reator EGSB ....................................5

Figura 5.13: Microscopia de contraste de fase das amostras do reator: (a) bacilos, (b) filamentos septados, (c) bacilos curvos, (d) sarcinas, (e) sarcinas e bacilos e (f) cistos. 61 Figura 5.14: Microscopia de fluorescência das amostras do reator. (a) bacilos fluorescentes e morfologia semelhante a Methanosarciana sp. (b) e (c) bacilos

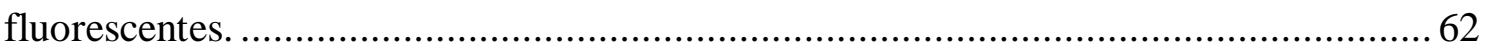

Figura 5.15: Analise quantitativa das populações microbianas .................................. 65

Figura 5.16: Microscopia de Contraste de Fase do NMP. (a) Sarcinas, (b) e (c) bacilos curvos e (d) bacilos, diplococos e espirilo. 
Figura 5.17: Porcentagem dos clones da região do copo e leito relacionados as diferentes famílias com base nos dados RDP classifier, .......................................... 72

Figura 5.18: Curva de rarefação dos clones da região do copo do reator ...................... 78

Figura 5.19: Curva de rarefação dos clones do leito do reator.....................................79

Figura 5.20 Árvore filogenética dos clones relacionados ao filo Firmicutes. A barra de escala informa a distância filogenética e Methanosarcina sp. foi escolhida como outgroup. 81

Figura 5.21: Árvore filogenética dos clones relacionados ao filo Protebacteria. A barra de escala informa a distância filogenética e Methanosaeta sp. foi escolhida como outgroup. 82

Figura 5.22: Árvore filogenética dos clones relacionados ao filo Synergistetes e Verrucomicrobia. A barra de escala informa a distância filogenética e Methanosarcina sp. foi escolhida como outgroup. 83 Figura 5.23: Árvore filogenética dos clones relacionados ao filo OP10, Actinobacteria, Acidobacteria, Chloroflexi e Bacteroidetes. A barra de escala informa a distância filogenética e Methanosarcina sp. foi escolhida como outgroup .84 


\section{LISTA DE TABELAS}

Tabela 4.1: Parâmetros de Operação do reator EGSB nas diferentes etapas ................. 17

Tabela 4.2: Parâmetros estabelecidos em cada etapa de operação ............................... 18

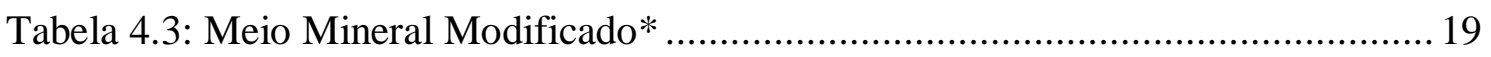

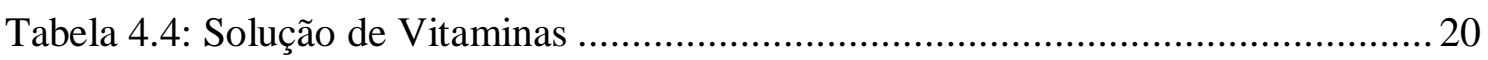

Tabela 4.5: Análises de monitoramento do reator EGSB ........................................... 21

Tabela 4.6: Quantificação de microrganismos nas diferentes etapas ...........................24

Tabela 4.7: Soluções para água de diluição .............................................................25

Tabela 4.8: Formas de detecção para as diferentes populações microbianas.................22

Tabela 4.9: Primers para amplificação da região 16S do domínio Bacteria ..................30

Tabela 4.10: Programação do termociclador para os primers do domínio Bacteria ....... 30

Tabela 4.11: Soluções para amplificação usando primers 27F e 1100R ........................ 30

Tabela 4.12: Componentes do Meio Luria-Bertani (LB) .......................................... 31

Tabela 4.13: Componentes do meio LB para crescimento da E.coli transformada........ 32

Tabela 4.14: Primers específicos para amplificação do DNA plasmidial ..................... 32

Tabela 4.15: Programação do termociclador para amplificação do DNA plasmidial ....32

Tabela 4.16: Soluções para reação de seqüenciamento usando primer $27 \mathrm{~F}$................... 33

Tabela 4.17: Programação do termociclador para reação de seqüenciamento ................ 33

Tabela 4.18: Programas utilizados para analisar as seqüências de DNA...................... 34

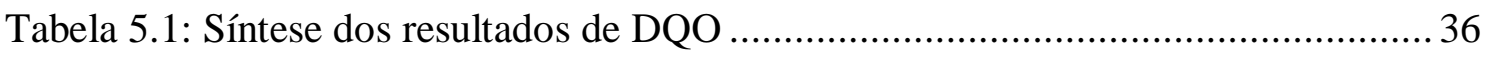

Tabela 5.2: Síntese dos resultados de LAS no reator EGSB ....................................... 38

Tabela 5.3: Comparação dos resultados obtidos com a literatura ............................... 42

Tabela 5.4: Valores médios de $\mathrm{pH}$, alcalinidade, sulfato e sulfeto.............................. 43

Tabela 5.5: Resultados de sólidos do reator EGSB ................................................... 46

Tabela 5.6: Distribuição do diâmetro dos grânulos nas diferentes etapas ..................... 48

Tabela 5.7: Média de ácidos voláteis totais efluente nas etapas de operação do reator .49

Tabela 5.8: Valores da extração de LAS no leito e SST efluente .................................54

Tabela 5.9: Balanço de massa LAS afluente/efluente e porcentagem de remoção ........56

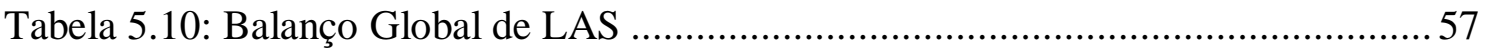

Tabela 5.11: Caracterização morfológica da biomassa do leito e copo nas diferentes

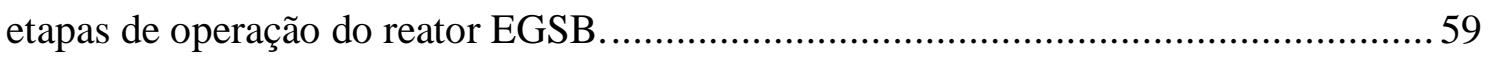

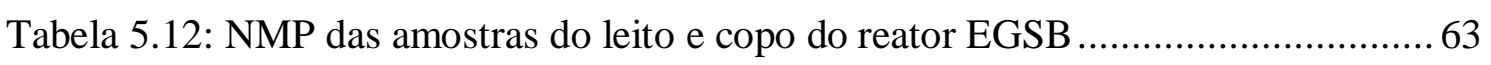

Tabela 5.13: Proporção dos filos encontrados em cada amostra* ............................... 68 
Tabela 5.14: Proporção de classes do filo Proteobacteria em cada amostra*

Tabela 5.15: Proporção dos filos encontrados em alguns trabalhos sobre remoção de LAS em diferentes configurações de reatores

Tabela 5.16: Números de UTOs e clones considerando distância evolutiva de 0,03. (C) 


\section{LISTA DE SIGLAS}

ABS - alquilbenzeno sulfonado

ASBR - reator operado em bateladas seqüencias (anaerobic sequencing batch reactor)

BRF - Bactérias Redutoras de Ferro

BRS - Bactérias Redutoras de Sulfato

CG - Cromatografia Gasosa

COV - Carga Orgânica Volumétrica

DGGE - Eletroforese em Gel de Gradiente Desnaturante

DNA - Ácido Dessoxiribonucléico

DQO - Demanda Química de Oxigênio

EGSB - leito de manta de lodo granulado expandido (expanded granular sludge bed)

ETE - Estação de Tratamento de Esgoto

HLPC - Cromatografia Líquida de Alta Eficiência

LAS - Alquilbenzeno Linear Sulfonado (Linear Alkylbenzene Sulfonate)

LPB - Laboratório de Processos Biológicos

NCBI - National Center for Biotechnology Information

NMP - Número Mais Provável

PCR - Reação em Cadeia da Polimerase

pH - potencial hidrogeniônico

RAHLF - Reator Anaeróbio Horizontal de Leito Fixo

RALF - reator anaeróbio de leito fluidificado

RDP - Ribossomal database project

RNA - Ácido Ribonucléico

SIP - Stable Isotope Probe

SDS - Dodecil Sulfato de Sódio

SPC - Sulfofenil Carboxilato (sulfophenil carboxilate)

ST - Sólidos Totais

STV - Sólidos Totais Voláteis

TDH - Tempo de Detenção Hidráulica

UASB - Reator Anaeróbio de Fluxo Ascendente e Manta de Lodo (Upflow Anaerobic

Sludge Blanket)

UTO - unidade taxonômica operacional 


\section{LISTA DE SÍMBOLOS}

[LAS] = concentração de LAS afluente/efluente $(\mathrm{mg} / \mathrm{L})$

A = média da concentração de LAS extraído no SST efluente (mg/gST)

$\mathbf{B}=$ sólidos totais efluente na etapa IV $(\mathrm{g} / \mathrm{L})$

$\mathbf{L A S}_{\text {ads. gran. }}$ = massa de LAS adsorvido nos grânulos do leito do reator EGSB

LAS ads. SST efl. = massa de LAS adsorvido nos grânulos do leito do reator EGSB

LAS degradado = massa de LAS removida por processos biológicos

LAS removido = massa de LAS removida por processos biológicos e físicos

$\mathbf{L A S}_{\text {ads }}=$ massa de LAS adsorvido (neste caso: SST efluente e biomassa do leito)

$\mathbf{L A S}_{\mathbf{a f l}}=$ massa de LAS afluente

$\mathbf{L A S}_{\text {efl }}=$ massa de LAS efluente

Massa $\operatorname{LAS}_{(\mathbf{A f l} / \mathbf{E f l})}=$ massa de LAS acumulada no afluente/efluente

$\mathbf{Q}=$ vazão afluente/efluente $(\mathrm{L} / \mathrm{h})$

$\mathbf{T}=$ tempo de operação do reator $(\mathrm{h})$

$\mathbf{V}=$ volume do reator $(\mathrm{L})$

$\mathbf{V}_{\text {ef }}=$ volume total do efluente durante todo o período de operação do reator (L)

$\boldsymbol{\alpha}=$ média da concentração de LAS extraído dos grânulos no leito do reator $(\mathrm{mg} / \mathrm{gST})$

$\boldsymbol{\beta}=$ sólidos totais do reator na etapa IV $(\mathrm{g} / \mathrm{L})$ 


\section{SUMÁRIO}

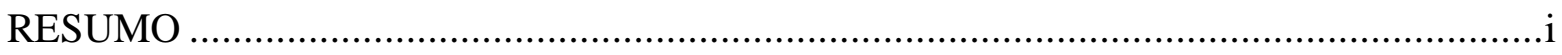

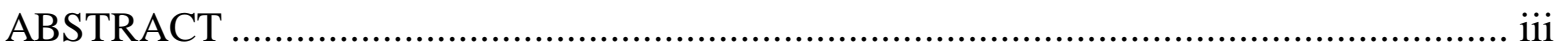

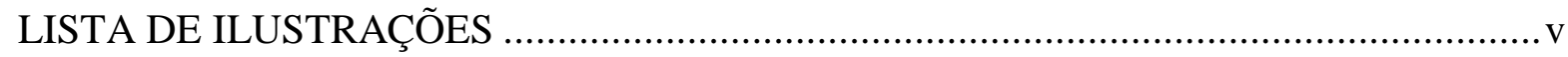

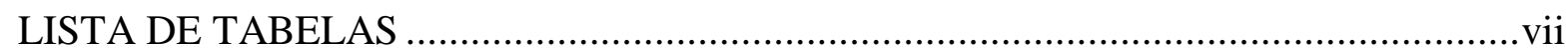

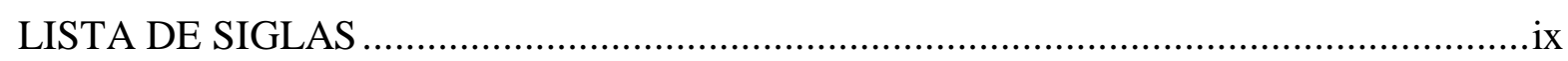

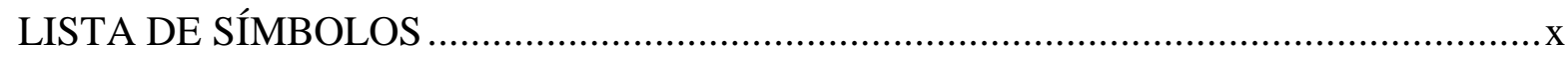

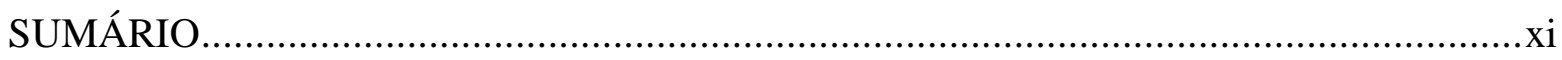

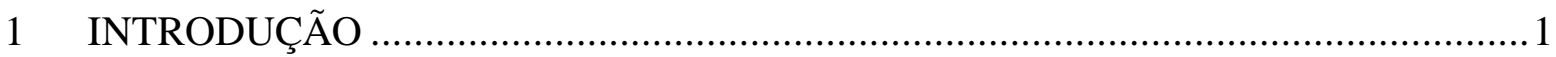

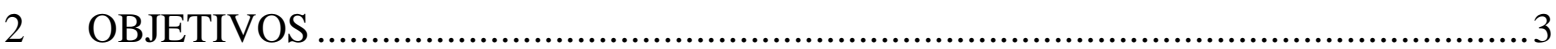

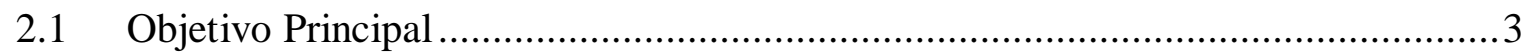

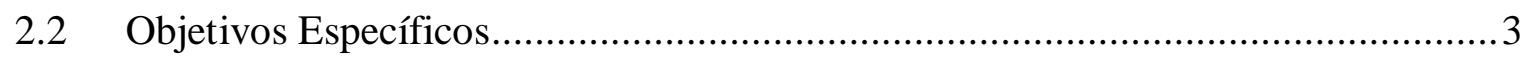

3 REVISÃO BIBLIOGRÁFICA _......................................................................

3.1 Alquilbenzeno Linear Sulfonado .............................................................. 4

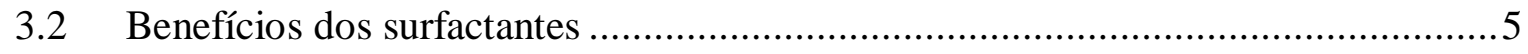

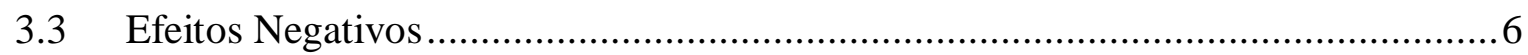

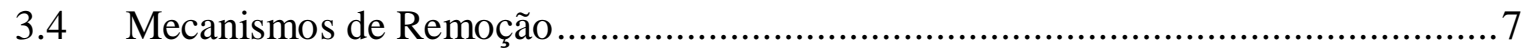

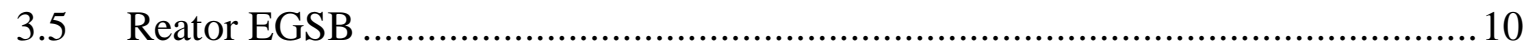

4 MATERIAL E MÉTODOS ........................................................................... 15

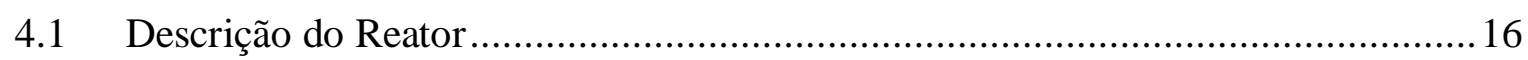

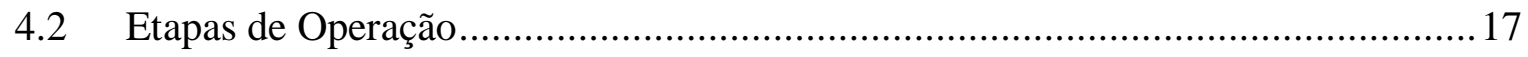

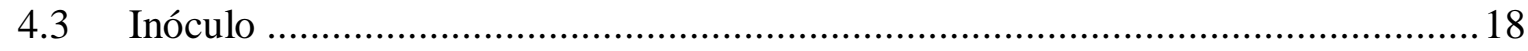

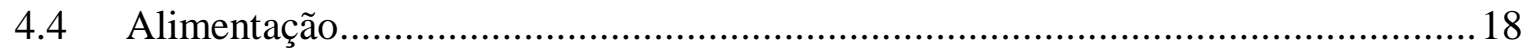

4.5 Análises Físico-Químicas e Cromatográficas ....................................................20

4.6 Monitoramento da Expansão do Leito ...............................................................2 21

4.7 Avaliação do Potencial Redox do Reator..........................................................22

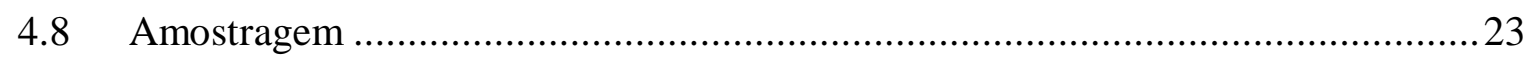

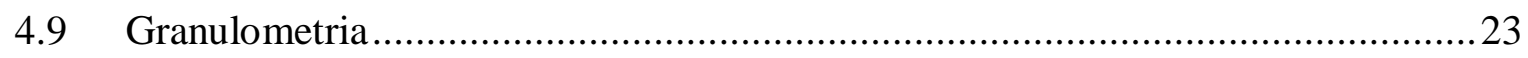

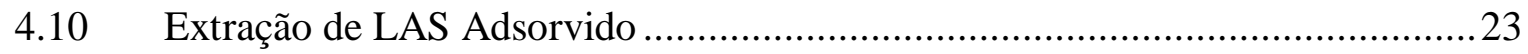

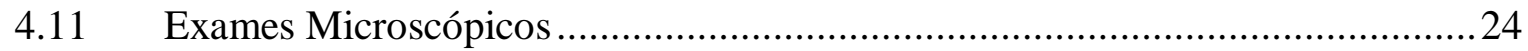

4.12 Análise Quantitativa da Diversidade Microbiana .........................................24

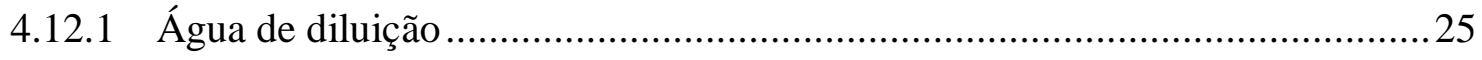

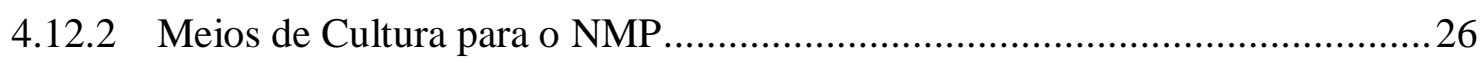




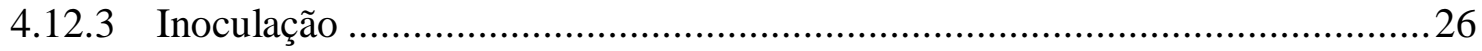

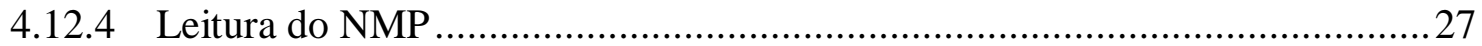

4.13 Análise Qualitativa da Diversidade Microbiana ...............................................28

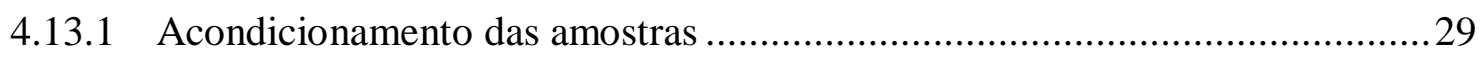

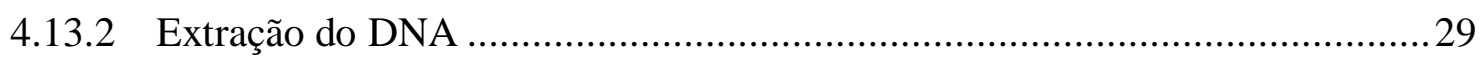

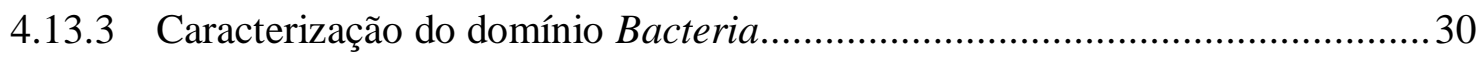

4.13.4 Clonagem, Amplificação do DNA plasmidial e Seqüenciamento ...................31

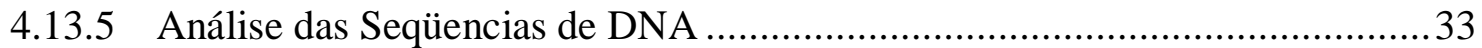

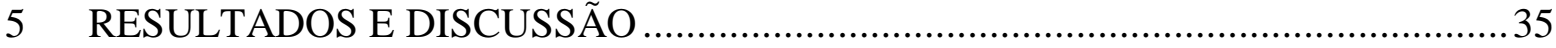

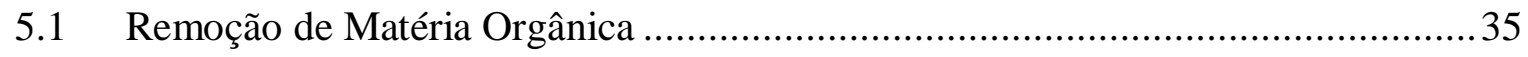

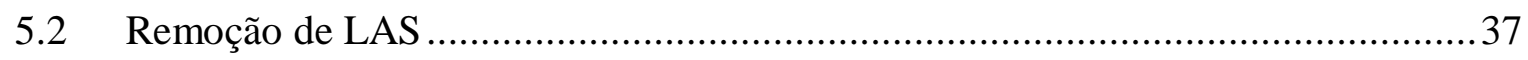

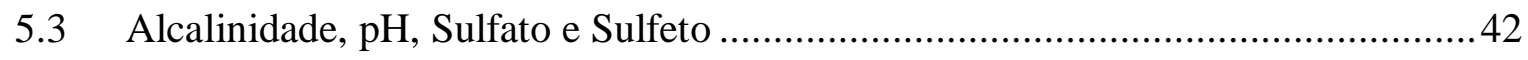

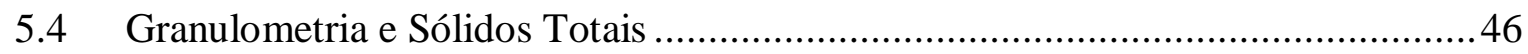

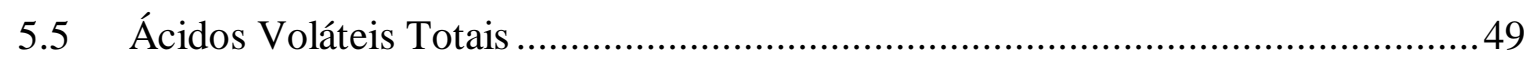

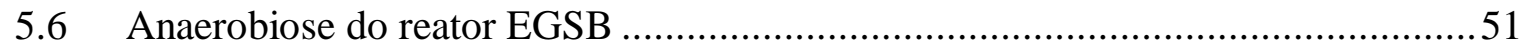

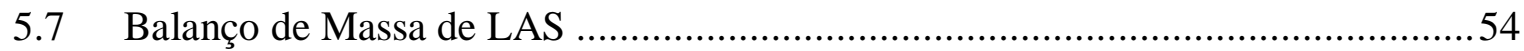

5.7.1 Balanço de Massa Afluente e Efluente ..........................................................56

5.7.2 Balanço de Massa nos Grânulos do leito do reator ........................................56

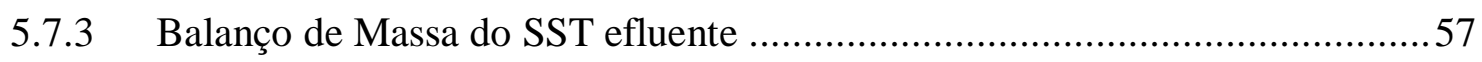

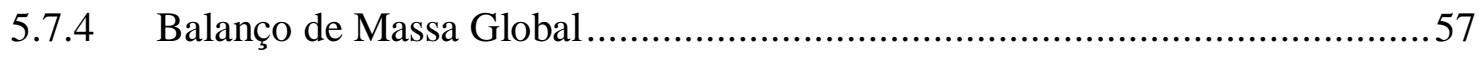

5.8 Microscopia de Contraste de Fase e Fluorescência .............................................59

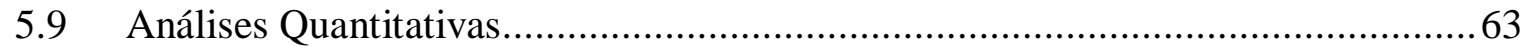

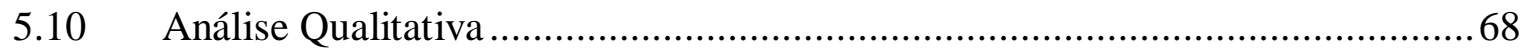

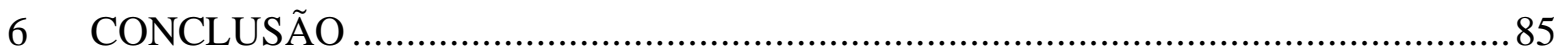

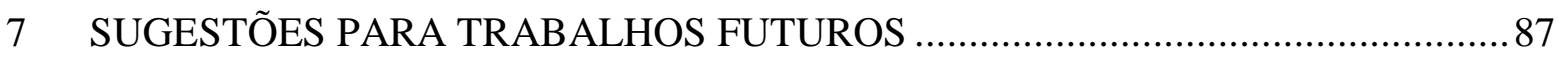

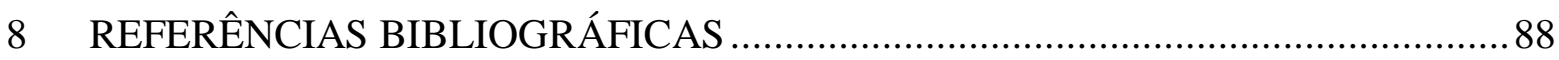

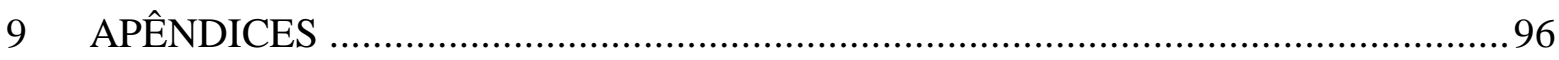




\section{INTRODUÇÃO}

Surfactantes são compostos orgânicos que possuem comportamento anfifílico. A parte hidrofóbica geralmente é composta de cadeias alquílicas ou alquilfenílicas, contendo de 10 a 18 átomos de carbono e a região hidrofílica é constituída por grupos iônicos ou não-iônicos ligados à cadeia carbônica. Tais propriedades são à base para uma gama de aplicações importantes, por exemplo, na formulação de agroquímicos, fármacos e produtos de consumo (xampus, condicionadores), no combate a vazamento de petróleo e, ainda, em outros usos específicos (PENTEADO et al., 2006)

O principal tensoativo aniônico sintético surgiu na década de 40, o alquilbenzeno sulfonado (ABS), a partir de precursores derivados do petróleo (benzeno e tetrâmero de propileno). Devido a sua alta recalcitrância e baixo potencial de biodegradação o ABS foi substituído por alquilbenzeno linear sulfonado (LAS) por ser considerado biodegradável.

Em virtude da participação majoritária do LAS dentre os tensoativos aniônicos nas formulações de detergentes de uso doméstico e industrial, e do elevado consumo mundial, tem sido alvo de interesse de pesquisadores, principalmente, envolvendo sua degradação e conseqüentemente remoção de água residuária, tanto industrial como doméstica. Uma vez que apresenta relevante impacto ao meio ambiente e sobre os organismos vivos.

Em vista da recalcitrância do LAS em condições anaeróbias, diversos estudos foram realizados no Laboratório de Processos Biológicos - LPB (Escola de Engenharia de São Carlos/USP), empregando as seguintes configurações de reatores: horizontal de leito fixo com biomassa imobilizada (DUARTE et al., 2008; OLIVEIRA et al., 2009), batelada seqüencial (DUARTE et al., 2010) e leito fluidificado (DE OLIVEIRA et al., 2010b).

Dentre esses reatores, o de leito fluidificado usando areia como material suporte foi o que apresentou melhor eficiência de remoção (acima de 90\%) (Oliveira et al., 2010). Todavia, o custo de bombeamento para fluidificação de um leito de areia torna esse reator menos atraente para aplicação em escala real. O reator de leito de lodo expandido (Expanded Granular Sludge Bed - EGSB) utiliza lodo granulado, cuja expansão exige menor vazão de bombeamento quando comparado com o leito de areia. Suas características são similares ao reator de leito fluidificado, isto é, regime de mistura completa, alta relação comprimentodiâmetro e adequado para diluir água residuária quando aplicada a recirculação efluente (SEGHEZZO et al., 1998)

Portanto, outra possibilidade de degradação e remoção de LAS é a utilização de reator anaeróbio EGSB. Tal configuração corresponde a um reator UASB (upflow anaerobic 
sludge blanket) modificado. Todavia, o EGSB apresenta recirculação que resulta na diluição do afluente e alta velocidade ascensional, o que permite maior transferência de massa. Tais condições podem contribuir para remoção de compostos recalcitrantes, como o LAS. Dessa forma, a motivação dessa pesquisa foi avaliar a remoção do LAS nesse reator e caracterizar filogeneticamente as bactérias presentes na biomassa granulada na presença do surfactante. 


\section{OBJETIVOS}

\subsection{Objetivo Principal}

O objetivo principal desse trabalho foi analisar a eficiência de remoção do surfactante aniônico, linear alquilbenzeno sulfonado (LAS), no reator EGSB, e caracterizar filogeneticamente a diversidade de bactérias na presença desse surfactante.

\subsection{Objetivos Específicos}

Avaliar a eficiência de remoção da matéria orgânica;

Avaliar a produção de ácidos orgânicos voláteis;

Caracterizar a dinâmica morfológica do lodo granulado;

Determinar o tamanho dos grânulos em função da operação do reator;

Avaliar quantitativamente a população de bactérias anaeróbias totais, bactérias redutoras de ferro e arquéias metanogênicas em cada etapa de operação do reator EGSB; 


\section{REVISÃO BIBLIOGRÁFICA}

As vantagens físico-químicas dos surfactantes aniônicos, em especial o LAS, resultam na sua larga produção industrial e, conseqüentemente, implicações em todo o mundo. Por trás dos benefícios atribuídos ao arranjo dessa molécula encontra-se uma série de problemas de ordem toxicológica que resultam em danos ambientais. Todavia, a interação entre esse surfactante e moléculas biológicas não está totalmente elucidado. Sabe-se que podem ligarse às proteínas modificando suas estruturas e atividades, acarretando disfunção do sistema como um todo. Dessa forma, faz se necessário aprofundar o conhecimento sobre a remoção do LAS do esgoto sanitário e água residuária, além de fornecer subsídios para compreender sua relação com meio biológico. A remoção por processos anaeróbios é viável, entretanto, ainda são necessários mais estudos com a finalidade de avaliar outras possibilidades de reatores anaeróbios, como por exemplo, o EGSB.

\subsection{Alquilbenzeno Linear Sulfonado}

Surfactantes constituem uma importante classe de produtos industriais químicos amplamente utilizados em quase todos os setores da indústria moderna. São compostos orgânicos que possuem comportamento anfifílico. Cerca de $54 \%$ do total de surfactantes produzidos foram aplicados no uso doméstico, contra apenas, $32 \%$ destinados ao uso industrial (BANAT et al., 2000).

Devido às excelentes propriedades e custo relativamente baixo, LAS é o surfactante aniônico mais amplamente utilizando em todo o mundo (GARCIA et al., 2005), presente em água residuária industrial e esgoto doméstico. Comercialmente, o LAS é vendido como uma mistura de homólogos e isômeros de posição de cadeias alquiladas lineares variando de $\mathrm{C}_{10}$ a $\mathrm{C}_{16}$ com predominância de $\mathrm{C}_{10}$ a $\mathrm{C}_{13}$.

A presença de LAS em água residuária é devido às atividades domésticas ( 1 a 22mg/L) e pode variar, em função do seu uso em processos industriais (SCOTT \& JONES, 2000). Estruturalmente é constituído de uma cadeia alquílica, com diferentes números de átomos de carbono (de 10 a 14), enquanto a outra parte, hidrofílica corresponde ao anel aromático sulfonado. $\mathrm{O}$ grupo sulfonado pode estar ligado a qualquer átomo de carbono com exceção aos carbonos terminais da cadeia alquílica (Figura 3.1). 


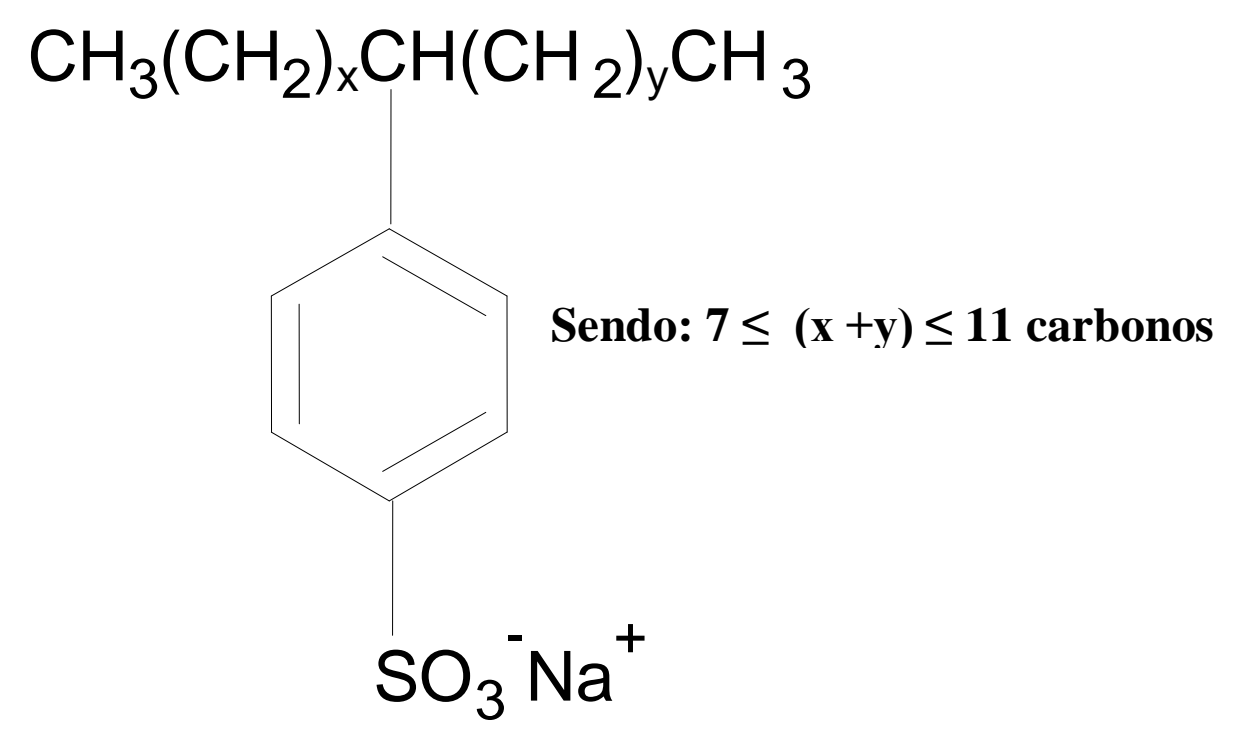

Figura 3.1: Estrutura do alquilbenzeno linear sulfonado

Fonte: JENSEN et al. (1999)

\subsection{Benefícios dos surfactantes}

Surfactantes são compostos anfipáticos, que possuem uma região hidrofílica e uma hidrofóbica. Essas regiões permitem a interação com outras moléculas, tais como, proteínas, celulose e com mistura de compostos polares e apolares. Como conseqüências ocorrem diminuição da energia de interação entre as fases heterogêneas em muitos processos tecnológicos e sistemas biológicos, como por exemplo, óleo-água, poliestireno-água e interface ar-água (YING, 2006).

Segundo Gould et al., (2000) surfactantes aniônicos podem influenciar consideravelmente a eficiência de um medicamento quando presente em formulações farmacêuticas, pela ligação direta com a droga; além disso, influencia o processos de adsorção entre compartimentos hidrofóbicos e hidrofílicos nos órgãos do organismo.

A plasticidade da molécula de surfactantes aniônicos permite a interação com superfícies hidrofóbicas e hidrofílicas que podem formar micelas que facilitam a solubilização de ampla gama de poluentes ambientais. Segundo Iglesias-Jimenez et al., (1997), tensoativos aniônicos podem promover a remoção dos pesticidas do solo com formação de compostos ricos em carbono. Essa possibilidade está relacionada com a concentração do surfactante e hidrofobicidade do pesticida. Singh et al., (2000) analisaram o pesticida Carbofuran e verificaram que surfactantes aniônicos e catiônicos podem influenciar diferentemente na sua eficácia de remoção. 
A mobilidade de poluentes orgânicos e inorgânicos entre vários sistemas pode ser influenciada pela presença de surfactantes aniônicos. Huang et al., (1997) observaram dessorção de partículas de chumbo do solo com a adição de surfactantes. Assim como, redução de cádmio livre pela complexação com um biossurfactante aniônico produzido por Pseudomonas aeroginosa (TAN et al., 1994). Muramoto et al., (1989) observaram diminuição da absorção de elementos, tais como, cádmio, níquel, alumínio, cálcio e manganês na raiz do aguapé (Eichhornia crassipes) na presença de surfactantes aniônicos.

Rajput et al., (1994), observaram que surfactantes catiônicos (Emcol CC9 e Emcol CC-36) apresentaram menor eficácia na remoção de compostos orgânicos recalcitrantes, tais como, 1,2,4-triclorobenzeno, anilino, fenol e 2,4 diclorofenol do solo, em relação aos outros surfactantes como Witconol (não iônico) e Emphos (aniônicos).

Park \& Jaffe, (1993), afirmaram que o surfactante aniônico (Emcol CNP-60) não apenas facilitam a dissolução e remoção de diversos poluentes ambientais, mas, podem aumentar a adsorção sob determinadas condições. Por exemplo, aumentaram a adsorção do tetracloreto, naftaleno e fenantreno na superfície de óxido de alumínio resultando num controle mais eficaz da remoção de poluentes da água.

\subsection{Efeitos Negativos}

Muitos esforços têm sido dedicados na compreensão dos efeitos adversos dos surfactantes aniônicos sobre o meio ambiente, em especial o LAS. A toxicidade dos surfactantes está relacionada com o tipo de grupamento polar e com o comprimento da cadeia alquila apolar. Cadeias alquílicas maiores podem causar efeitos mais severos provocando destruição da membrana celular e desnaturação de proteínas. No caso específico da molécula de LAS, a localização do anel aromático mais próximo da extremidade da cadeia aquílica potencializa essa toxicidade.

Segundo Venhuis \& Mehrvar (2004) 40 a 60mg/L de LAS podem interferir na reprodução e crescimento de invertebrados do solo e apresentar efeitos agudos ao plâncton de água doce, além de bactérias e crustáceos. Segundo esses mesmos autores concentração média de 530mg LAS/Kg de massa seca a 16.000mg LAS/Kg de massa seca em lodo de esgoto, em curto prazo, desencadeou inibição da atividade biológica no solo. Tal constatação abre precedente em relação à disposição de lodo de estação de tratamento em áreas agricultáveis.

Outros impactos atribuídos ao LAS são os seguintes: formação de espuma e conseqüente inibição dos processos de autodepuração dos cursos d'água e disseminação de impurezas, 
danificação das membranas celulares e desnaturação de proteínas. Para organismos aquáticos, a toxicidade aguda de LAS varia entre $1,7 \mathrm{mg} / \mathrm{L}$ a $270 \mathrm{mg} / \mathrm{L}$, sendo Daphnia magna a mais sensível (VERGE \& MORENO, 2000).

Plantas expostas ao LAS apresentaram as membranas das células radiculares destruídas, alterações na permeabilidade e nos processos fisiológicos e fotossintéticos. Concentrações entre 5 a $10 \mathrm{mg} \mathrm{LAS/Kg}$ não geraram problemas na germinação e crescimento de plantas hidropônicas ou em outros meios de cultivo. No entanto, para valores mais elevados, entre 10 a $40 \mathrm{mg} \mathrm{LAS} / \mathrm{Kg}$, foram observados efeitos tóxicos (MIEURE et al., 1990).

Não apenas as bactérias, plantas aquáticas e invertebrados são sensíveis aos surfactantes aniônicos, mas alguns vertebrados apresentam sintomas típicos de toxicidade. Buhl \& Hamilton (2000) verificaram que o LAS $(5,0 \mathrm{mg} / \mathrm{L})$ foi aproximadamente cinco vezes mais tóxico do que o SDS (24,9 mg/L) em trutas juvenis da espécie Oncorhynchus mykiss.

\subsection{Mecanismos de Remoção}

Segundo HERA (Human and Environmental Risk Assesment, 2010), a remoção de LAS pode ocorrer pela combinação de três processos: precipitação, biodegradação e adsorção. A principal forma de remoção é a degradação microbiana, geralmente em torno de $80 \%$ (PAINTER \& ZABEL, 1989); precipitação e adsorção em sólidos suspensos podem representar de 30 a 70\% (BERNA et al., 1989).

Segundo Painter \& Zabel (1989) a degradação microbiana por processos aeróbios, em especial por lodos ativados podem remover mais de $95 \%$ de surfactantes aniônicos concentrados no esgoto sanitário (1 a $21 \mathrm{mg} / \mathrm{L}$ ). Trehy et al. (1996) obtiveram remoção de 99,5\% de LAS em quatro sistemas de lodos ativados usados no tratamento de esgoto sanitário.

Segundo Shörberl (1989) a rota de degradação do LAS sob condição aeróbia, consiste nos seguintes passos: (1) conversão oxidativa de um ou dois grupos metila da cadeia alquílica a um grupo carboxila ( $\omega$-/ $\beta$ - oxidação); (2) oxidação da cadeia alquílica ( $\beta$ oxidação); (3) oxidação do anel aromático; (4) quebra da ligação C-S, liberando sulfato (dessulfonação).

A degradação microbiana por processos anaeróbios têm sido estudada a partir de 2.000, utilizando em especial reatores UASB (ALMENDARIZ et al., 2001; MOGENSEN et al., 2003; SANZ et al., 2003; LOBNER et al., 2005), reator contínuo de mistura completa (CSTR) (MOGENSEN et al., 2003), reator anaeróbio horizontal de leito fixo (RAHLF) 
(OLIVEIRA et al., 2009; DUARTE et al., 2008), reator de leito fluidificado (RALF) (OLIVEIRA et al. 2010) e reator operado em bateladas seqüenciais (DUARTE et al., 2010).

Em relação ao reator UASB, Sanz et al. (2003) usaram carga de LAS afluente de 45mgLAS/L e tempo de detenção hidráulica de 24 horas com inóculo proveniente de reator UASB de indústria de açúcar de beterraba. Na primeira etapa, os autores alimentaram o reator com substratos facilmente degradáveis, tais como, acetato, propionato, butirato, lactato, metanol, etanol e sacarose mais LAS comercial (4-5mgLAS/L), por três meses. Nessa fase, a remoção média foi de $64 \%$. A segunda etapa a remoção média foi de $85 \%$ e consistiu apenas da alimentação com LAS comercial (4-5mgLAS/L), sem co-substratos.

Lobner et al., (2005) avaliaram a remoção de 10mg LAS/L em reator UASB (200mL) com TDH de 48 horas sob diferentes temperaturas $\left(55^{\circ} \mathrm{C}\right.$ e $\left.32^{\circ} \mathrm{C}\right)$. Os autores obtiveram remoção de 40-80\%, para as duas condições de temperatura testadas. Além disso, verificaram também que a melhor remoção de LAS foi obtida quando da presença de baixas concentrações de ácidos voláteis $(<20 \mathrm{mg} / \mathrm{L}$ de ácido acético).

DUARTE et al., 2010, avaliaram a remoção de LAS em reator RAHFL inoculado com lodo proveniente de reator UASB utilizado no tratamento de esgoto de dejetos de suinocultura. O reator foi operado com tempo de detenção hidráulica de 12 horas contendo espuma de poliuretano como material suporte e alimentação com substrato sintético e duas concentrações de LAS (7mg/L e 14mg/L). Por meio do balanço de massa, os autores constataram remoção de $34 \%$ ao final de 314 dias de operação. Análises de DGGE com recorte de bandas possibilitaram evidenciar bactérias pertencentes ao grupo das BRS, as quais estão relacionadas com a remoção do LAS (DENGER \& COOK, 1997). Além disso, a identificação filogenética por meio do sequenciamento da região $16 \mathrm{~S}$ do RNAr indicou bactérias semelhantes ao filo Firmicutes e classe Clostridia, cujos microrganismos também são relacionados com a degradação de LAS (DENGER \& COOK, 1997).

OLIVEIRA et al., 2010 avaliaram a remoção de LAS em reator de leito fluidificado (volume total de $353 \mathrm{~mL}$ ) com diferentes materiais suportes (carvão ativado, argila expandida, pérolas de vidro e areia), sob condição mesofílica e TDH de 18 horas. Os reatores foram alimentados com substrato sintético e inoculados com lodo granulado proveniente de reator UASB utilizado no tratamento de dejetos de suinocultura. Os autores observaram diferença na remoção do LAS em função dos diferentes materias suportes. A areia foi o material suporte que possibilitou maior remoção; ou seja, de $99 \%$ para concetração afluente média de 18,8mg LAS/L. A análise filogenética permitiu evidenciar bactérias pertencentes ao filo Bacteroidetes, filo Proteobacteria, filo Actinobacteria entre 
outros. Tais resultados, abriram precedente para utilização de reator de alta taxa na remoção de compostos tóxicos, tais como, LAS.

DUARTE et al. (2010), verificaram a remoção de LAS, sob condição mesofílica, em reator anaeróbio em bateladas seqüencias $(5 \mathrm{~L})$ contendo biomassa granulada proveniente de reator UASB usado no tratamento de dejetos de suinocultura. O reator foi operado com ciclos de 24 horas a 50rpm e alimentado com substrato sintético, contendo os seguintes compostos: extrato de levedura, amido e sacarose com fontes de carbono facilmente biodegradáveis, e $22 \mathrm{mg}$ LAS/L. Na ausência de co-substratos foi obtida a maior remoção de LAS; ou seja, de 53\%. Na presença de co-substratos esse valor foi de 24 a $37 \%$. Os autores notaram alteração na remoção de matéria orgânica em função da adição do LAS, de $74 \%$ (etapa sem LAS) para 44\% quando da adição do surfactante. Analises de DGGE para o domínio Bacteria e Archaea revelaram diferenças durante as etapas de operação, principalmente quando da adição do surfactante, quanto na etapa sem co-subtratos e digestão do lodo. A análise filogenética indicou bactérias pertencentes ao filo Bacteroidetes, Proteobacteriae, Verrumicrobia, entre outros.

Em relação a degradação anaeróbia do LAS, algumas constatações foram verificadas, por exemplo, por MOGENSEN et al., (2003) que detectaram ácido benzeno sulfônico e benzaldeído sob essa condição. Benzeno e tolueno foram encontrados em efluente de reator anaeróbio alimentado com LAS (Duarte et al., 2010).

Lara-Martin et al., (2010) observaram a rota de degradação do LAS utilizando sedimento marinho anóxico como inóculo para testes em batelada usando frasco de $300 \mathrm{~mL}$. Para tanto, foram criados microcosmos com o sedimento coletado no litoral de Cádiz, na Espanha, com $\mathrm{N}_{2}$ e $\mathrm{CO}_{2}$ no headspace (80:20, proporção volume), concentração de LAS $(10,20$ e 50 ppm) e rezasurina com indicado de ambiente anóxico. Segundo os autores ocorreu remoção de $79 \%$ em 165 dias de operação. Inicialmente, ocorreu adição de fumarato a molécula de LAS, biotransformação em ácido sulfofenil carboxílico (SPC) e sucessivas reações de $\beta$-oxidação (Figura 3.2). 

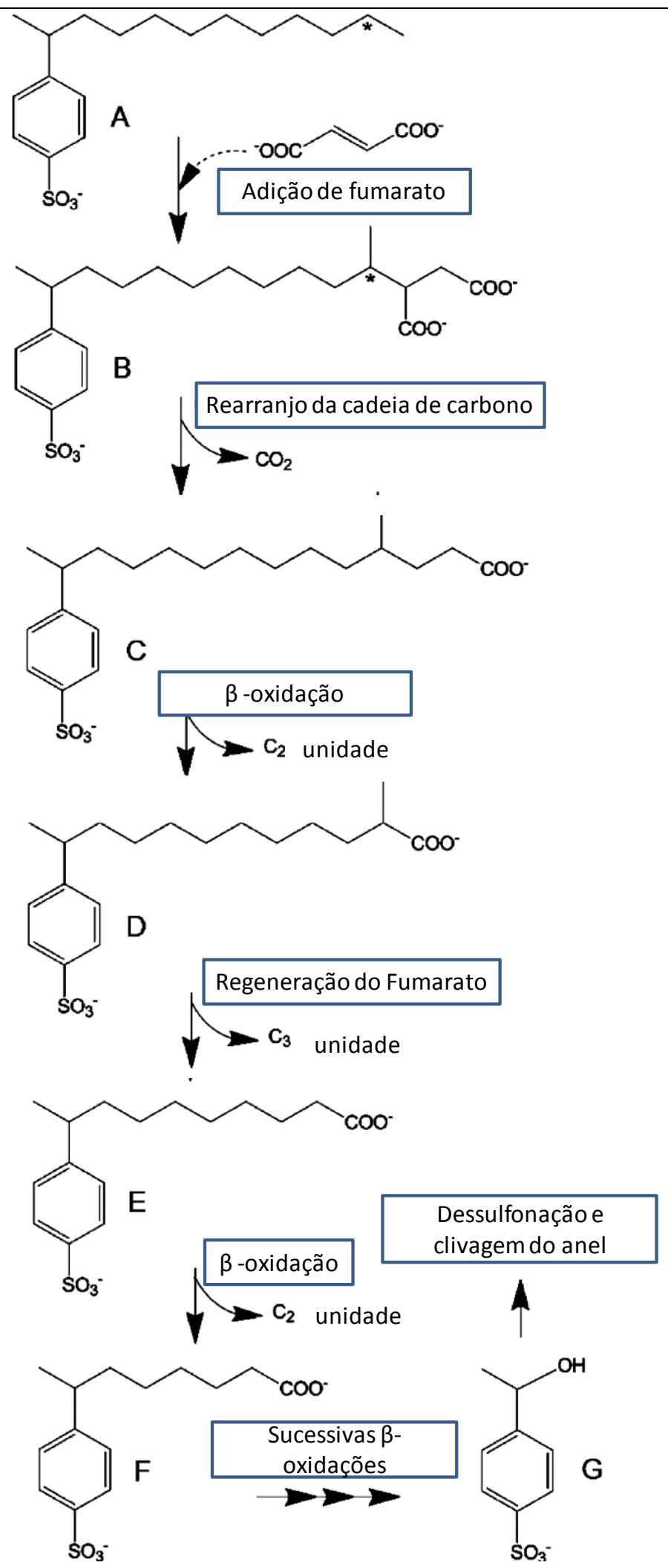

Figura 3.2: Rota de degradação anaeróbia

Fonte: Lara-Martin et al., (2010)

O reator EGSB (Expanded Granular Sludge Bed), leito de manta de lodo granulado expandido (KATO et al., 1994), foi concebido com alternativa aos reatores anaeróbios 
consagrados, tais como, o reator UASB (Upflow Anaerobic Sludge Blanket) (LETTINGA et al., 1980). Suas características são similares à do reator UASB, porém, com relação altura/diâmetro maior, ou seja, da ordem de 20, onde são aplicadas velocidades ascensionais acima de $2,5 \mathrm{~m} / \mathrm{h}$, podendo chegar até $10 \mathrm{~m} / \mathrm{h}$ (KATO et al., 1994). Tais características evitam fluxos preferenciais, curtos-circuitos hidráulicos e zonas mortas.

Velocidades ascensionais elevadas são necessárias para promover a expansão ou fluidificação da partícula; seja um material suporte específico (areia) ou lodo granulado. $\mathrm{Na}$ prática, é considerado um reator de leito expandido quando ocorre expansão da ordem de $10 \%$ a $20 \%$ do leito estático inicial. Acima desses valores é considerado reator de leito fluidificado (CAMPOS, 1999).

A diluição do afluente promovida pela aplicação de recirculação do efluente em reator de leito fluidificado e leito de manta granulada expandida permite o tratamento de compostos tóxicos. Poluentes solúveis são eficientemente tratados nesse reator, entretanto, os sólidos suspensos não são removidos substancialmente devido à alta velocidade ascencional $\left(\mathrm{V}_{\mathrm{a}}\right)$ (SEGHEZZO et al., 1998). Alguns fatores contribuem para a eficiência de reator de leito expandido/fluidificado, tais como:

1) Máximo contato entre o líquido e meio suporte;

2) São evitados problemas de canais preferenciais, empacotamento e retenção de gás, comumente encontrados em leito fixo;

3) Melhor estabilidade e eficiência de remoção de DQO, quando comparado com o reator anaeróbio de manta de lodo (UASB);

4) Pode ser operado para ampla faixa de concentração de matéria orgânica;

5) Menor requisito de área;

6) Diluição do afluente quando aplicada recirculação, por conseguinte, em caso de remoção de compostos tóxicos permitindo a sua diluição.

O reator EGSB apresenta grande potencialidade quando aplicado no tratamento de esgoto sanitário predominantemente solúvel de baixa e alta concentração, simples ou complexo.

Kato et al., 1994, avaliaram a remoção de até 100 a 200mg DQO/L em reator EGSB sob condição mesofílica. Os autores obtiveram remoção de matéria orgânica superior a $80 \%$. Trata-se de contribuição importante para entender o comportamento do reator EGSB sob baixa concentração de matéria orgânica.

Nuñez e Martinez (1999) analisaram o desempenho do reator EGSB para tratar água residuária de abatedouro de aves sob condição mesofílica. A carga orgânica total afluente foi 
de $15 \mathrm{kgDQO} . \mathrm{m}^{-3} \cdot \mathrm{d}^{-1}$, TDH de 5 horas e inóculo proveniente do tratamento de efluente de fábrica de cerveja. Os autores obtiveram remoção de 67\% de DQO e, aproximadamente, 90\% dos sólidos suspensos totais. Esses resultados indicam que o reator EGSB apresenta eficiência significativa quando aplicado altas cargas orgânicas.

Costa et al., (2007) estudaram o comportamento do reator EGSB exposto a dois choques tóxicos utilizando detergente comercial. Os autores utilizaram reator ESGB de 1,15 $\mathrm{L}$ de volume útil, temperatura de $37^{\circ} \mathrm{C}, 1500 \mathrm{mg} / \mathrm{L}$ de $\mathrm{DQO}$ afluente (etanol) e detergente comercial composto de glicol éter (1-10\%), surfactante aniônico (1-10\%), aditivos de performance $(1-10 \%)$ e corantes $(<1 \%)$. O detergente comercial apresentou DQO de $98 \mathrm{~g} / \mathrm{L}$, dessa forma, o choque tóxico foi realizado com: (I) $150 \mathrm{mgDQO} / \mathrm{L}$ de detergente comercial durante $56 \mathrm{~h}$ e (II) $300 \mathrm{mgDQO} / \mathrm{L}$ de detergente comercial durante $222 \mathrm{~h}$. Os resultados obtidos foram os seguintes: a remoção de DQO permaneceu inalterada no primeiro choque tóxico, todavia, ocorreu redução de $75 \%$ para $17 \%$ na remoção de DQO no segundo choque tóxico. A atividade metanogênica específica no primeiro choque foi estimulada durante as primeiras $8 \mathrm{~h}$, diminuindo após esse período e recuperada 5 dias, após o choque tóxico. Todavia, no choque tóxico II a atividade metanogênica foi imediatamente reduzida durante todo o período de exposição.

Deve-se considerar também em relação ao reator EGSB a importância da biomassa granulada. A estrutura e evolução dinâmica estão diretamente relacionadas com as populações microbianas presentes nos grânulos. As distintas populações microbianas são resultado direto de características, tais como, comportamento hidráulico do reator, fontes de alimentação e presença de material suporte.

MacLeod et al. (1900) estudaram a estrutura do grânulo a partir da biomassa de reator UASB alimentado com sacarose $(4,4 \mathrm{~g} / \mathrm{L})$ e extrato de levedura $(44 \mathrm{~g} / \mathrm{L})$, correspondendo a 1,3 gDQO/gSSV.d. De acordo com os autores três camadas distintas foram estabelecidas, a mais interna corresponde as arquéias metanogênicas, as quais podem agir como centros de nucleação, seguido por bactérias anaeróbias que utilizam e produzem $\mathrm{H}_{2}$ e, por último, na região mais externa bactérias filamentosas, além de cocos e bacilos (

Figura 3.3). 


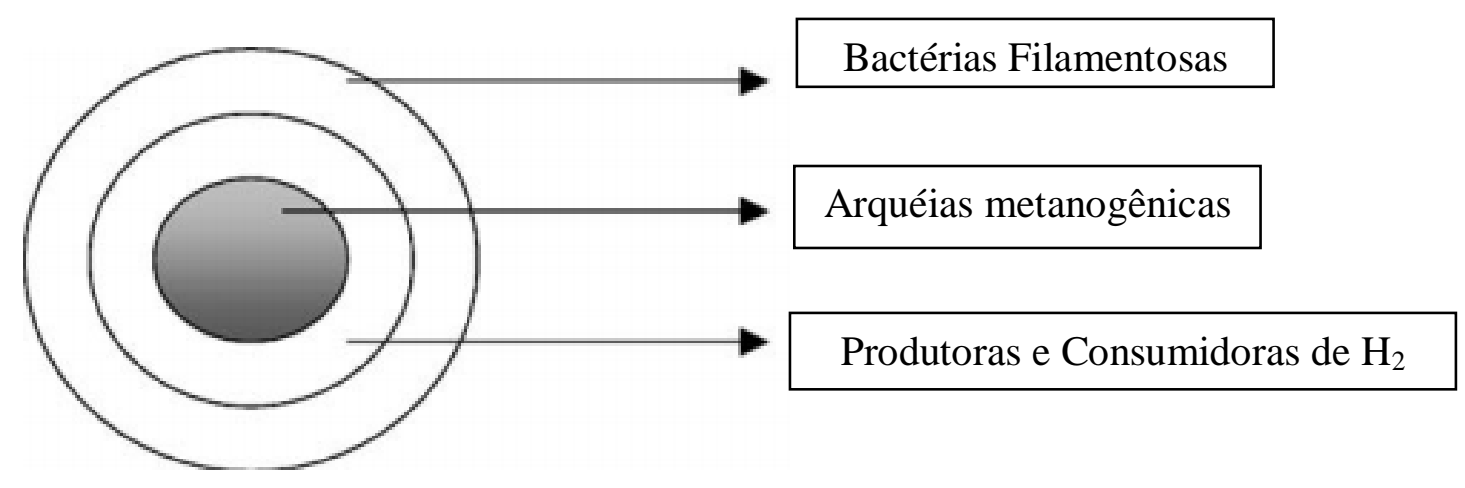

Figura 3.3: Estrutura do grânulo do UASB

Fonte: MacLeod et al. (1990)

Ganzaloez-Gil et al. (2001), analisaram a estrutura granulada de reator EGSB utilizado no tratamento de água residuária de processamento de batata e açúcar, com TDH de 2 horas, condição mesofílica, carga orgânica volumétrica de $20 \mathrm{KgDQO} / \mathrm{m}^{3}$.d e eficiência de remoção de $70-75 \%$. Esses autores propuseram a conformação granulada representada na Figura 3.4.

Diferentemente de MacLeod et al. (1900), Ganzaloez-Gil et al. (2001) não notaram camadas contínuas de grupos microbianos com metabolismos específicos, mas, um mosaico de agrupamentos microbianos com a mesma predisposição metabólica, como por exemplo grupos de Methanosarcina.

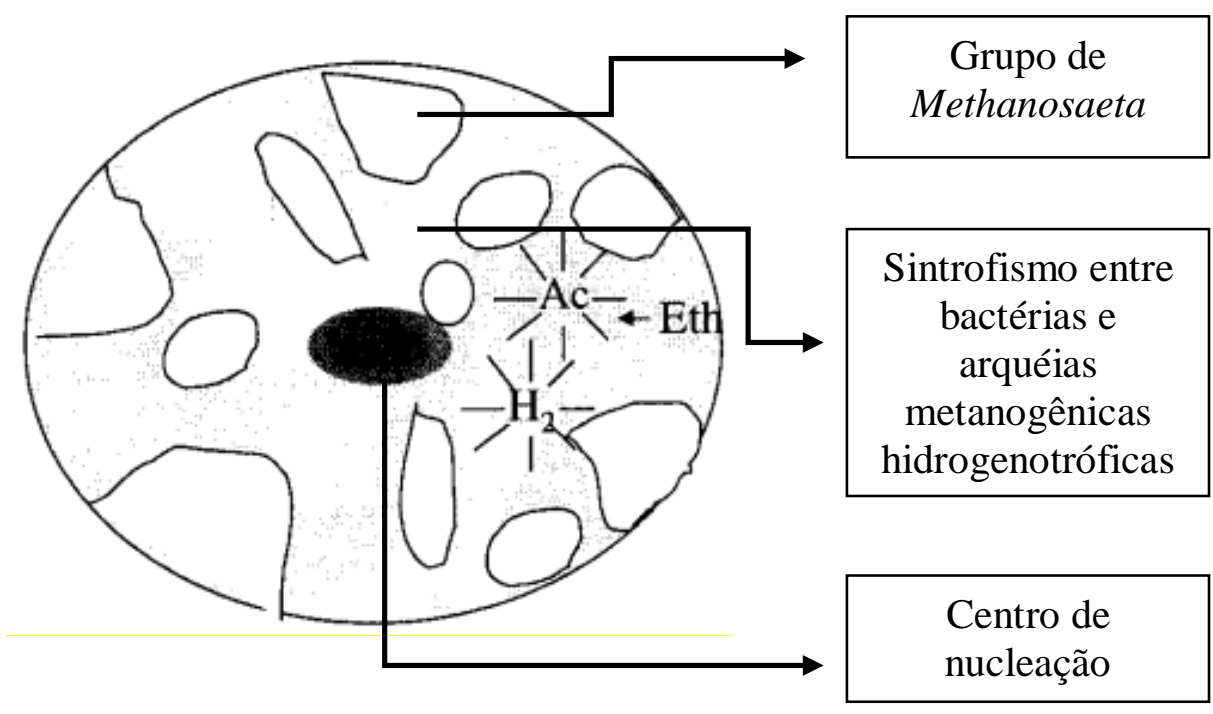

Figura 3.4: Estrutura do grânulo para EGSB

Fonte: Gonzalez-Gil et al., (2001) 
Embora, ocorra distinção entre a composição microbiana e sua disposição nos grânulos é indiscutível as vantagens atribuídas a granulação. Segundo McHugh et al. (2003), tais vantagens são as seguintes: (a) melhora a eficiência de proliferação microbiana, (b) acessa recursos e nichos que não poderiam ser utilizados por células isoladas, (c) gradiente interno de processos físico-químicos, (d) defesa coletiva, provavelmente, em relação a compostos tóxicos, (e) otimização da sobrevida das populações microbianas, uma vez que, há diferentes tipos celulares, e (f) geração de efluente com baixa quantidade de sólidos em suspensão. Portanto, o confinamento das bactérias anaeróbias e arquéias metanogênicas na biomassa granulada auxilia na proteção e tolerância à compostos tóxicos e, em outros casos, adaptação a compostos inibitórios (RAZO-FLORES et al., 1996). 


\section{MATERIAL E MÉTODOS}

Esse trabalho teve por finalidade analisar a eficiência de remoção do alquilbenzeno linear sulfonado em reator EGSB utilizando lodo granulado obtido de tratamento de efluente de abatedouro de aves. Na Figura 4.1 encontra-se delineado o fluxograma geral que detalha as etapas experimentais e análises realizadas durante a execução do trabalho.

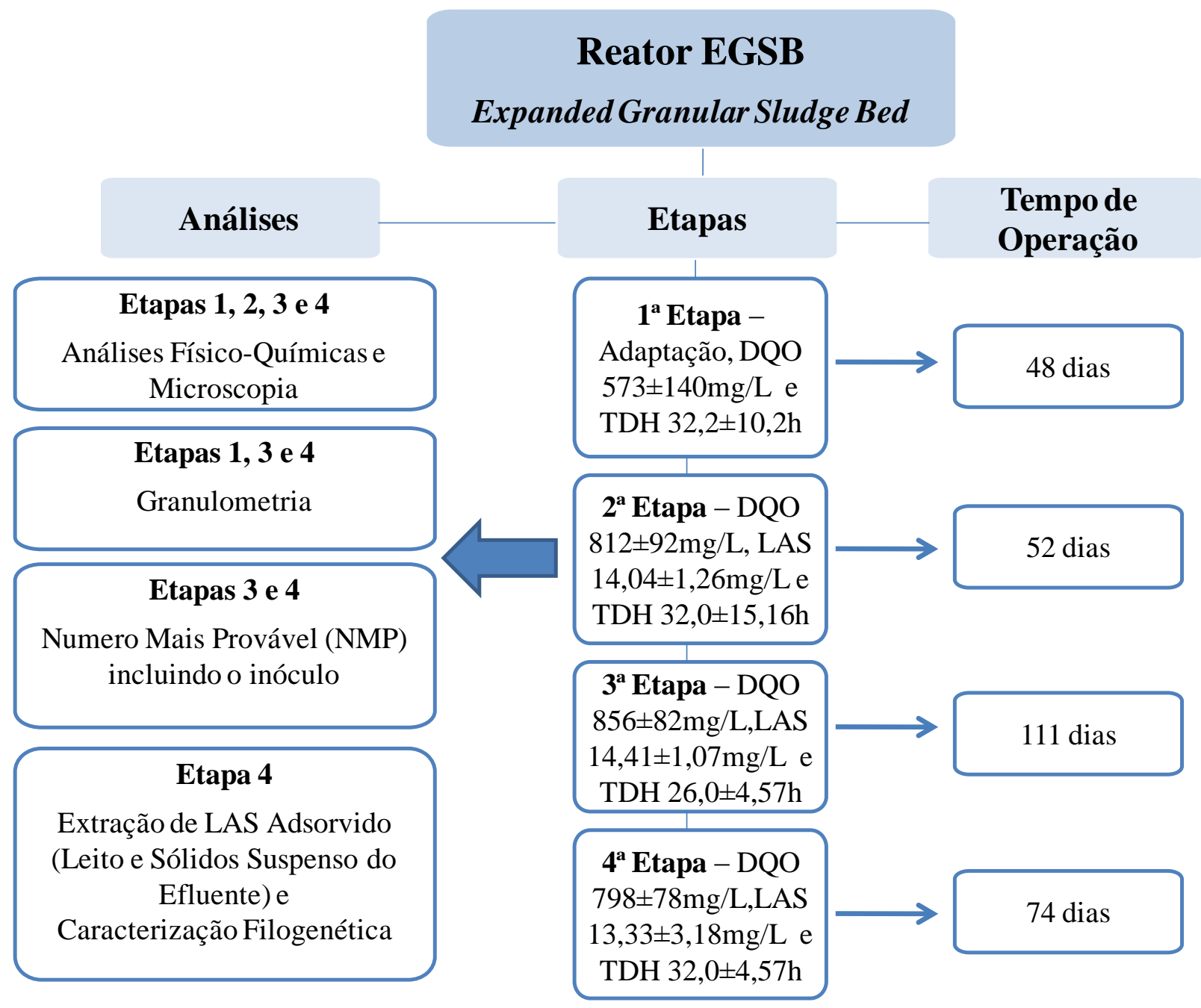

Figura 4.1: Fluxograma Experimental Geral

Conforme pôde ser observado na Figura 4.1, algumas análises não foram realizadas. Por exemplo, a análise granulométrica da Etapa 2 não foi realizada devido a dificuldade de retirada dos grânulos nessa etapa. A quantificação microbiana pela técnica dos tubos múltiplos (NMP) não foi realizada nas Etapa I e II. 


\subsection{Descrição do Reator}

O reator foi confeccionado em acrílico, com volume útil de 1,5 $\mathrm{L}$, com um dispositivo na extremidade superior para garantir a separação entre as fases sólida, líquida e gasosa, e um distribuidor de vazão na sua base. Ao longo do leito do reator foram instalados seis pontos de amostragem e um na região do copo (separador de fase). A Figura 4.2 detalha as características do reator EGSB. Durante a operação o reator foi mantido em condição mesofílica, a $30^{\circ} \mathrm{C}$, em câmara climatizada.

Com o intuito de garantir a anaerobiose do sistema dois procedimentos foram adotados: primeiro, a utilização de um selo hídrico e segundo, a utilização de um sifão na saída do sistema o que evitou a entrada de oxigênio pela mangueira do efluente.
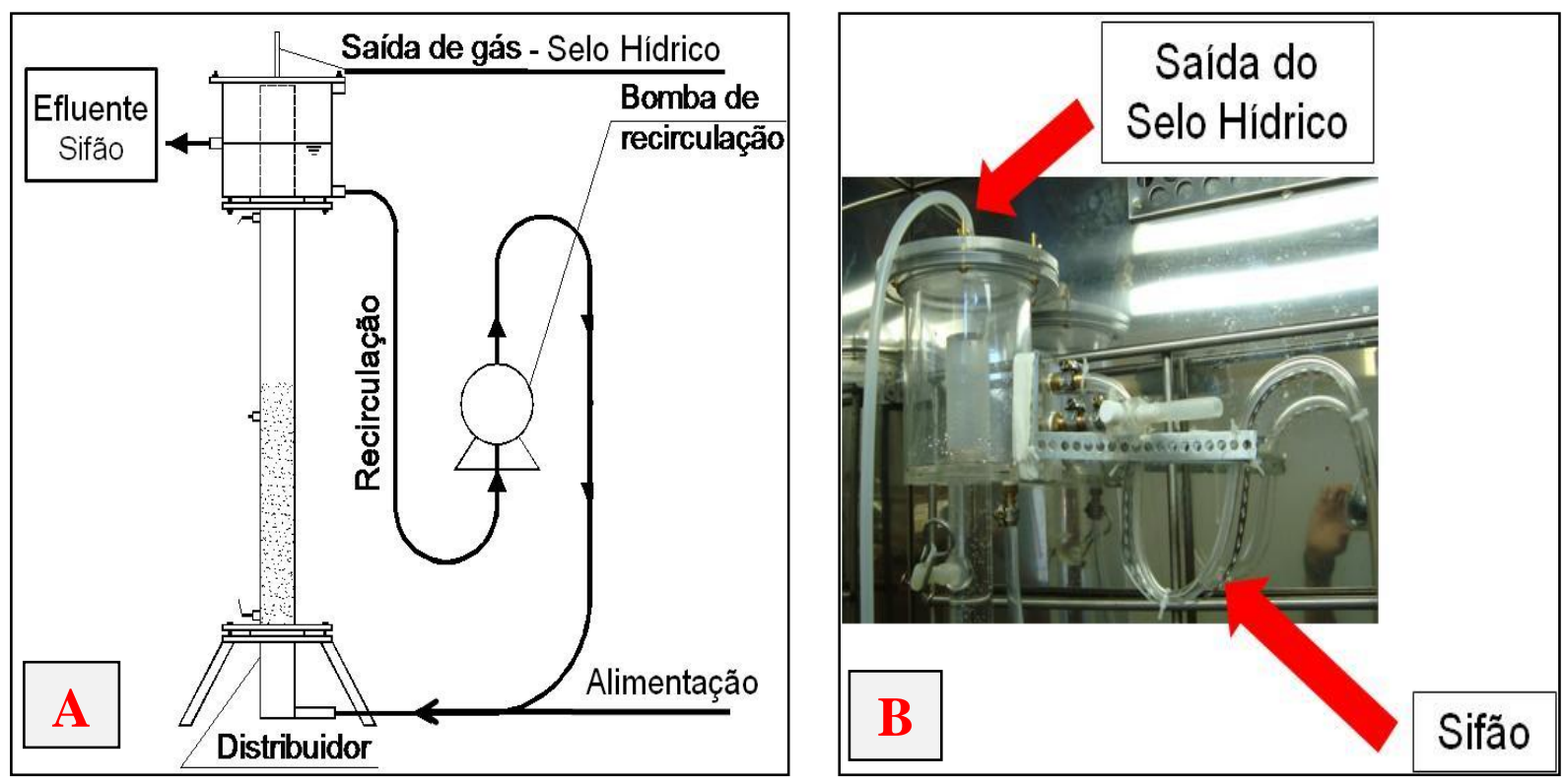

Figura 4.2: Detalhes do reator EGSB. (A) esquema do reator,

(B) detalhe do selo hídrico e sifão

A opção por utilizar lodo granulado sem material suporte foi devido às menores vazões de recirculação necessárias para expansão do leito. Na Tabela 4.1 estão apresentados os parâmetros de operação intrínsecos do reator. Para cada etapa de operação foi imposto TDH específico que resultou numa vazão de alimentação média. A vazão de recirculação foi fixa durante todo o período de operação do reator de $5 \mathrm{~L} / \mathrm{h}$. Isso resultou em uma diluição acentuada da alimentação e, conseqüentemente, da concentração de LAS. A recirculação promove a diluição de compostos tóxicos como o LAS, além de aumentar a transferência de 
massa. Segundo Seghezzo et al. (1998), a diluição do afluente promovido pela recirculação do efluente pode favorecer a remoção e degradação de compostos tóxicos.

Tabela 4.1: Parâmetros de Operação do reator EGSB nas diferentes etapas

\begin{tabular}{cccccc}
\hline Etapa & TDH* $^{*}$ & $\begin{array}{c}\text { Volume do } \\
\text { Reator }\end{array}$ & $\begin{array}{c}\text { Vazão } \\
\text { Recirculação }\end{array}$ & $\begin{array}{c}\text { Vazão } \\
\text { Alimentação* }\end{array}$ & $\begin{array}{c}\text { Fator } \\
\text { Diluição }\end{array}$ \\
\hline- & (h) & $(\mathrm{L})$ & L/h & L/h & - \\
\hline I & 32 & & & 0,039 & 128 \\
II & 32 & 1,5 & 5 & 0,047 & 106 \\
III & 26 & & & 0,058 & 86 \\
IV & 32 & & & 0,047 & 106 \\
\hline
\end{tabular}

* Média dos valores obtidos

Dessa forma, na etapa de adaptação (I) a diluição do afluente foi de 128 vezes para vazão média de alimentação de $0,039 \mathrm{~L} / \mathrm{h}$. Na etapa II e IV a vazão de alimentação foi similar; ou seja, de 0,047 L/h com diluição de 106 vezes. Na etapa III, com TDH de 26 horas, a vazão de alimentação foi maior $(0,058 \mathrm{~L} / \mathrm{h})$ e diluição de 86 vezes.

\subsection{Etapas de Operação}

O reator EGSB foi operado por 285 dias, os quais foram divididos em quatro etapas, em função do TDH. A Etapa I foi realizada para adaptação da biomassa às características hidráulicas do reator e alimentação. Para tanto, foi realizado período de adaptação de 48 dias no qual não houve adição de LAS. Ultrapassado esse período, iniciaram-se as etapas onde o LAS foi adicionado na alimentação.

Nas etapas II e IV o reator foi operado de modo semelhante. A iniciativa de realizar a etapa IV semelhante à etapa II foi devido aos resultados de remoção de LAS. O TDH influencia diretamente na carga de LAS aplicada; ou seja, valor maior de TDH resulta em carga de LAS menor, enquanto, valor menor resulta em carga de LAS maior. Dessa forma, ao realizar a etapa IV semelhante à etapa II teve por objetivo analisar o comportamento do reator depois de uma carga de LAS mais elevada (etapa III), com a finalidade de avaliar se a remoção de LAS seria igual ou menor em relação aquela observada na etapa II.

Na Tabela 4.2 estão detalhados os parâmetros específicos de cada etapa. 
Tabela 4.2: Parâmetros estabelecidos em cada etapa de operação

\begin{tabular}{|c|c|c|c|}
\hline Etapa & Alimentação & $\begin{array}{c}\text { Duração } \\
\text { (dias) }\end{array}$ & $\begin{array}{c}\text { TDH } \\
\text { (h) }\end{array}$ \\
\hline I & $\begin{array}{l}\text { meio mineral modificado, solução de } \\
\text { vitaminas, bicarbonato de sódio e co- } \\
\text { substratos }\end{array}$ & 48 & $32,2 \pm 10,2$ \\
\hline II & $\begin{array}{c}\text { meio mineral modificado, solução de } \\
\text { vitaminas, bicarbonato de sódio, co- } \\
\text { substratos e adição de } 14,04 \pm 1,26 \mathrm{mg} / \mathrm{L} \text { de } \\
\text { LAS }\end{array}$ & 52 & $32,0 \pm 15,16$ \\
\hline III & $\begin{array}{c}\text { meio mineral modificado, solução de } \\
\text { vitaminas, bicarbonato de sódio, co- } \\
\text { substratos e adição de } 14,41 \pm 1,07 \mathrm{mg} / \mathrm{Lde} \\
\text { LAS }\end{array}$ & 111 & $26,0 \pm 4,57$ \\
\hline IV & $\begin{array}{l}\text { meio mineral modificado, solução de } \\
\text { vitaminas, bicarbonato de sódio, co- } \\
\text { substratos e adição de } 13,33 \pm 3,18 \mathrm{mg} / \mathrm{L} \text { de } \\
\text { LAS }\end{array}$ & 72 & $32,0 \pm 4,57$ \\
\hline
\end{tabular}

\subsection{Inóculo}

O inóculo foi proveniente de reator UASB usado no tratamento de água residuária de abatedouro de aves (Avícola Dakar S/A, Tietê/SP). Para a inoculação, o lodo granulado foi lavado com água destilada para a retirada de impurezas advindas do sistema de tratamento de abatedouro de aves. Logo em seguida, foi adicionado $300 \mathrm{~mL}$ de lodo granulado com concentração de sólidos totais $(\mathrm{g} / \mathrm{L})$ de 9,13 , sólidos totais fixos $(\mathrm{g} / \mathrm{L})$ 1,39 e sólidos totais voláteis $(\mathrm{g} / \mathrm{L})$ de 7,74, de acordo com a metodologia descrita em Standard Methods for Examination of Water and Wastewater (APHA et al., 2005).

\subsection{Alimentação}

O reator foi alimentado com os seguintes co-substratos facilmente degradáveis: etanol $(0,27 \mathrm{~mL} / \mathrm{L})$ e metanol $(0,34 \mathrm{~mL} / \mathrm{L})$ perfazendo DQO teórica de aproximada de 800 mg/L, meio mineral modificado (ANGELIDAKI et al., 1990), descrito na Tabela 4.3, solução de vitaminas (Tabela 4.4) (TOUZEL \& ALBAGNAC, 1983) e LAS obtido da Aldrich (CAS 25155-30-0) com 99,9\% de pureza. 
Tabela 4.3: Meio Mineral Modificado*

Solução A - Solução B • Solução C

\begin{tabular}{|c|c|c|c|}
\hline Componentes & $\begin{array}{c}\text { Concentração } \\
(\mathrm{mg} / \mathrm{L})\end{array}$ & $\begin{array}{c}\text { Componentes } \\
\text { (cont.) }\end{array}$ & $\begin{array}{c}\text { Concentração } \\
(\mathrm{mg} / \mathrm{L})\end{array}$ \\
\hline - $\mathrm{NH}_{4} \mathrm{Cl}$ & 1.000 & $\mathrm{MnCl}_{2} \cdot 4 \mathrm{H}_{2} \mathrm{O}$ & 0,05 \\
\hline - $\mathrm{NaCl}$ & 100 & $\Delta\left(\mathrm{NH}_{4}\right)_{6} \mathrm{Mo}_{7} \mathrm{O}_{24} \cdot 4 \mathrm{H}_{2} \mathrm{O}$ & 0,05 \\
\hline${ }^{\Delta} \mathrm{MgCl}_{2} \cdot 6 \mathrm{H}_{2} \mathrm{O}$ & 25 & ${ }^{\Delta} \mathrm{AlCl}_{3}$ & 0,05 \\
\hline${ }^{\Delta} \mathrm{CaCl}_{2} \cdot 2 \mathrm{H}_{2} \mathrm{O}$ & 50 & ${ }^{\Delta} \mathrm{CoCl}_{2} \cdot 6 \mathrm{H}_{2} \mathrm{O}$ & 0,05 \\
\hline - $\mathrm{K}_{2} \mathrm{HPO}_{4} .3 \mathrm{H}_{2} \mathrm{O}$ & 400 & ${ }^{\Delta} \mathrm{NiCl}_{2} \cdot 6 \mathrm{H}_{2} \mathrm{O}$ & 0,092 \\
\hline${ }^{\Delta} \mathrm{FeCl}_{2} \cdot 4 \mathrm{H}_{2} \mathrm{O}$ & 2 & $\boldsymbol{\Delta}$ EDTA & 0,5 \\
\hline${ }^{\Delta} \mathrm{H}_{3} \mathrm{BO}_{3}$ & 0,05 & ${ }^{\Delta} \mathrm{HCl}$ concentrado & $1 \mathrm{~mL} / \mathrm{L}$ \\
\hline$\Delta \mathrm{ZnCl}_{2}$ & 0,05 & $\Delta \mathrm{Na}_{2} \mathrm{SeO}_{3} .5 \mathrm{H}_{2} \mathrm{O}$ & 0,1 \\
\hline${ }^{\Delta} \mathrm{CuCl}_{2} \cdot 2 \mathrm{H}_{2} \mathrm{O}$ & 0,038 & & \\
\hline
\end{tabular}

*Modificação da concentração de $\mathrm{MgCl}_{2}$

Fonte: Angelidaki et al., 1990

Os componentes do meio mineral modificado foram divididos em três grupos em relação às características químicas principalmente de solubilidade. Para tanto, periodicamente era preparado uma solução estoque A contendo apenas $\mathrm{NH}_{4} \mathrm{Cl}, \mathrm{NaCl}$, $\mathrm{MgCl}_{2} \cdot 6 \mathrm{H}_{2} \mathrm{O}$ e $\mathrm{CaCl}_{2} \cdot 2 \mathrm{H}_{2} \mathrm{O} 100$ vezes mais concentrada. A solução $\mathrm{B}$ foi preparada com $\mathrm{K}_{2} \mathrm{HPO}_{4} 500$ vezes mais concentrada. A Solução C foi preparada 1.000 vezes mais concentrada contendo os demais reagentes do meio mineral modificado. Esse procedimento foi adotado para facilitar a alimentação do reator e aumentar a confiabilidade na pesagem dos reagentes. Todas as soluções eram mantidas em frascos âmbares de 1L fechados e mantidas ao abrigo da luz.

Para a solução de vitaminas foi preparado solução estoque 200 vezes mais concentrada. Essa solução foi esterilizada por filtração em sistema Millipore em membrana de poro 0,22 $\mu \mathrm{m}$, previamente esterilizado em autoclave a $121^{\circ} \mathrm{C}$ e 1 atm, durante 20 minutos. Logo em seguida, procedeu-se a distribuição da solução em frascos de antibióticos $(25 \mathrm{~mL})$. Os frascos foram fechados com tampas de butila, lacrados e armazenados sob refrigeração. A cada alimentação era utilizado um frasco de antibiótico $(25 \mathrm{~mL})$ para um volume total de 5,5L de alimentação. 
Tabela 4.4: Solução de Vitaminas

\begin{tabular}{cc}
\hline Componentes & $\begin{array}{c}\text { Concentração } \\
(\mathbf{g} / \mathbf{L})^{*}\end{array}$ \\
\hline Biotina & 0,002 \\
Ácido fólico & 0,002 \\
Tiamina & 0,005 \\
Riboflavina & 0,005 \\
Ácido Nicotínico & 0,005 \\
Pantotenato de cálcio & 0,005 \\
Piridoxina & 0,01 \\
Vitamina B12 & 0,0001 \\
Ácido Lipóico & 0,005 \\
Ácido p-aminobenzóico & 0,005 \\
\hline
\end{tabular}

*q.s.p $1000 \mathrm{~mL}$ de água destilada anaeróbia

Fonte: Touzel e Albagnac, 1983.

$\mathrm{O}$ bicarbonato de sódio era estocado em pequenos frascos com a massa exata para o volume final de alimentação em temperatura ambiente.

A solução estoque de LAS (1g/L) foi preparada cuidadosamente evitando a formação de espuma. Essa solução foi armazenada em frasco de vidro e mantida sob refrigeração. Para volume total de alimentação de 5,5L foi adicionado $82,5 \mathrm{~mL}$ de solução estoque de LAS.

O procedimento para preparação da alimentação consistiu:

a) Limpeza do frasco de Duran®;

b) Preenchimento parcial do frasco com água da rede pública de abastecimento;

c) Adição das Soluções A, B e C, respectivamente. Entre cada adição o frasco foi agitado para homogeneização dos componentes do meio mineral.

d) Adição da Solução de vitaminas;

e) Adição de Bicarbonato de Sódio Comercial;

f) Completava-se o volume para próximo de 5,5L;

g) Adição do LAS;

h) Agitação moderada do frasco de alimentação;

i) Calibração do volume final.

\subsection{Análises Físico-Químicas e Cromatográficas}

Amostras do afluente e efluente foram analisadas seguindo as frequiências e parâmetros apresentados na Tabela 4.5. Análises de demanda química de oxigênio (DQO), 
$\mathrm{pH}$ (potencial hidrogeniônico), sólidos totais voláteis, sulfato e sulfeto foram realizadas de acordo com APHA (2005). A determinação da alcalinidade foi realizada de acordo com a metodologia de Dillalo e Albertson (1961) modificada por Ripley (1986).

Os ácidos voláteis foram determinados por cromatografia líquida de alta eficiência (CLAE), segundo metodologia de Lazaro et al. (2008). Tal metodologia permite a determinação dos seguintes ácidos: Capróico, Valérico, Isovalérico, Butírico, Isobutírico, Propiônico, Acético, Fórmico, Lático, Succínico, Málico e Cítrico.

As análises para a determinação da concentração de LAS foram realizadas segundo metodologia desenvolvida por Duarte et al. (2006) utilizando cromatografia líquida de alta eficiência.

Tabela 4.5: Análises de monitoramento do reator EGSB

\begin{tabular}{|c|c|c|c|}
\hline & Método & $\begin{array}{l}\text { Freqüência das } \\
\text { análises }\end{array}$ & Referência \\
\hline $\begin{array}{l}\text { Ácidos voláteis } \\
\text { (mg/L) }\end{array}$ & Cromatográfico & $2 \mathrm{X}$ semana & Lazaro et al. (2008) \\
\hline $\begin{array}{l}\text { Alcalinidade } \\
\left(\mathrm{mgCaCO}_{3} / \mathrm{L}\right)\end{array}$ & Titulométrico & $2 \mathrm{X}$ semana & $\begin{array}{c}\text { Dillalo e Albertson (1961) } \\
\text { modificada por Ripley et } \\
\text { al. }(1986)\end{array}$ \\
\hline $\begin{array}{l}\text { DQO bruta e } \\
\text { filtrada }(\mathrm{mg} / \mathrm{L})\end{array}$ & Espectrofotométrico & $2 \mathrm{X}$ semana & APHA (2005) \\
\hline $\mathrm{LAS}(\mathrm{mg} / \mathrm{L})$ & $\begin{array}{c}\text { Cromatográfico } \\
\text { HPLC }\end{array}$ & $2 \mathrm{X}$ semana & Duarte et al. (2006) \\
\hline $\mathrm{pH}$ (unidade) & Potenciométrico & $2 \mathrm{X}$ semana & APHA (2005) \\
\hline $\begin{array}{c}\text { Sólidos Totais } \\
\text { Voláteis }\end{array}$ & Gravimétrico & $1 \mathrm{X}$ semana & APHA (2005) \\
\hline Sulfato (mg/L) & Turbidimétrico & $1 \mathrm{X}$ semana & APHA (2005) \\
\hline Sulfeto (mg/L) & Espectrofotométrico & 1X semana & APHA (2005) \\
\hline Vazão (mL/h) & Volumétrico & diariamente & - \\
\hline $\begin{array}{l}\text { Potencial Redox } \\
(\mathrm{mV})\end{array}$ & Potenciométrico & 1x semana & - \\
\hline Expansão do Leito & - & 2x semana & - \\
\hline
\end{tabular}

\subsection{Monitoramento da Expansão do Leito}

O monitoramento da expansão do leito foi realizado utilizando uma régua para a medição da sua altura. Inicialmente, foi medida a altura do leito com a bomba de recirculação desligada $\left(\mathrm{H}_{0}\right)$ e logo em seguida era medido a altura do leito com a bomba de 
recirculação ligada $\left(\mathrm{H}_{1}\right)$. De acordo com Campos (1999), adotou-se que a altura da expansão do leito não ultrapassasse $30 \%$ da altura inicial (Figura 4.3
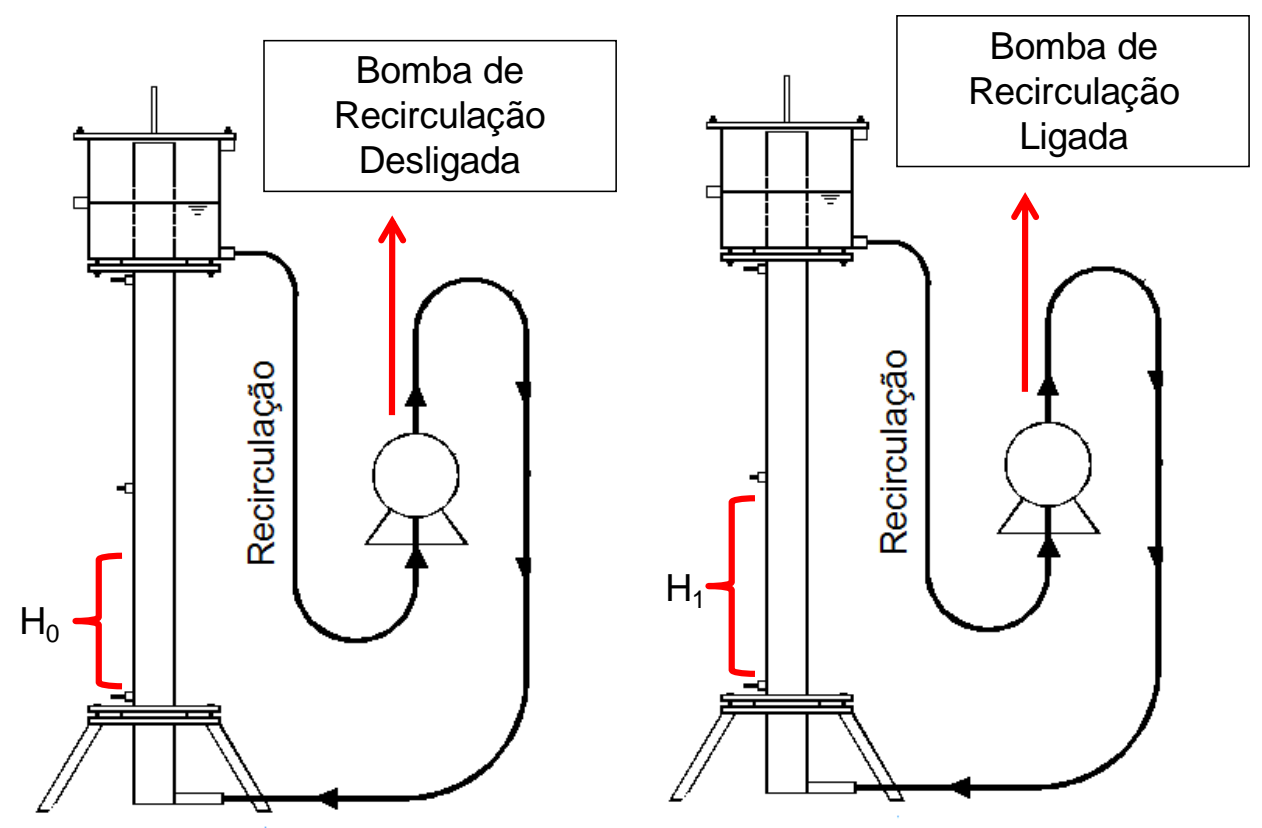

Figura 4.3: Esquema do monitoramento da expansão do leito do reator EGSB

Para o cálculo da altura de expansão foi usada a equação descrita a seguir:

$$
\begin{gathered}
\text { \% Expansão }=\left(\frac{\mathrm{H}_{1}}{\mathrm{H}_{0}} \times 100\right)-100 \\
10 \leq \% \text { Expansão } \leq 30
\end{gathered}
$$

\subsection{Avaliação do Potencial Redox do Reator}

No $190^{\circ}$ dia de operação foi avaliado o potencial redox do reator EGSB. O método consiste na diferenciação colorimétrica do corante resazurina de acordo com o potencial redox do meio. Coloração azul indica que o meio está aeróbio, enquanto, a ausência de cor (incolor) é indicativa de que o meio está anaeróbio. A cor rosa é característica de potencial redox entre 200 e $-200 \mathrm{mV}$, condição facultativa.

O experimento consistiu na adição de $1 \mathrm{~mL} / \mathrm{L}$ de resazurina $(0,1 \%)$ na mangueira de alimentação do reator. Durante aproximadamente 1 hora de experimento foi observado a 
coloração do meio e a retirada de fotos das mangueiras, bombas (alimentação e recirculação) e do leito do reator para documentação.

\subsection{Amostragem}

Para as análises descritas nos itens $(4.10,4.11,4.12,4.13$ e 4.14) a amostragem foi realizada como descrito abaixo.

Conforme o item 4.1, o reator EGSB possuía 6 pontos de amostragem ao longo do leito e 1 na região do copo. Dessa forma, para as análises da região do leito, era coletada uma amostra composta que consistia na retirada de seis porções de $5 \mathrm{~mL}$ de cada ponto de amostragem. Essas amostras eram transferidas para frascos apropriados e homogeneizadas para formar amostra única. Para as análises da região do copo a amostra era retirada do ponto de amostragem presente nessa região, em geral $10 \mathrm{~mL}$.

Todavia, para algumas análises, como extração de LAS adsorvido, foram retiradas amostras compostas do reator inteiro, incluindo os pontos de amostragem do leito e copo.

\subsection{Granulometria}

A granulometria do lodo granulado foi realizada ao final das etapas I, III e IV, utilizando o software Image-Pro Plus 4.5 para o tratamento das imagens, contagem e medição do diâmetro médio dos grânulos, segundo a metodologia adaptada de Alphenaar et al. (1993).

Para tanto foi retirada amostra composta ao final de cada etapa através dos pontos de amostragem do próprio reator (item 4.9). Os grânulos foram distribuídos sobre uma placa de Petri tomando cuidado com o espaçamento entre eles, evitando deixá-los muito próximos. Previamente, a captura da imagem foi colocada uma régua graduada junto à placa de Petri que serviu de referência para o software. Os dados foram exportados para a Microsoft Office Excel 2007 para tratamento estatístico e elaboração do histograma com intervalo de classe de $0,5 \mathrm{~mm}$.

\subsection{Extração de LAS Adsorvido}

A extração de LAS adsorvido foi realizada apenas ao final da operação do reator EGSB, segundo a metodologia modificada de Duarte (2006). Devido às características adsortivas do LAS e com o objetivo de fechar o balanço de massa desse surfactante, foi realizado a extração de LAS adsorvido na biomassa do leito e nos sólidos suspensos do efluente ambos em duplicata. 
As amostras do reator foram retiradas a partir dos pontos de amostragem do próprio reator. Enquanto, as amostras de SST efluente foram retiradas acondicionado $5 \mathrm{~L}$ do efluente em um frasco de Duran ${ }^{\circledR}$ seguido de filtragem em peneira de 7,5 $\mu \mathrm{m}$ e posterior secagem de acordo com o protocolo de Duarte (2006).

\subsection{Exames Microscópicos}

Os exames microscópicos de contraste de fase e fluorescência foram realizados em microscópio Olympus BX60 com câmera acoplada para captura de imagem e software Image-Pro Plus 4.5 nas Etapas I, II, III e IV. Para tanto, foi retirado uma amostra composta ao final de cada etapa.

A amostra foi acondicionada em frasco de antibiótico de $30 \mathrm{~mL}$ contendo pérolas de vidro. O frasco foi fechado com tampa de butila e lacrado com lacre de alumínio. Logo em seguida, procedeu-se a homogeneização da amostra para total ruptura dos grânulos. Parte da homogeneização foi manual (20 minutos) e parte (5 minutos) no vórtex.

Pequena quantidade da amostra foi adicionada a uma lâmina previamente limpa com detergente e álcool. Sob a gota foi colocada uma lamínula, também, previamente lavada. Cumprido todo esse procedimento a amostra foi observada no microscópio.

\subsection{Análise Quantitativa da Diversidade Microbiana}

Para estimar a população de microrganismos (bactérias anaeróbias totais, bactérias redutores de ferro e arquéias metanogênicas) presente no reator EGSB foi utilizado à técnica de tubos múltiplos por meio do Número Mais Provável. O conceito é bastante antigo, idealizado por McCrady (1915), entretanto foi adaptado por Sakamoto (1996) para quantificação da microbiota anaeróbia. O método consiste em diluições seriadas para contagem indireta da densidade de microrganismos em um líquido. Na Tabela 4.6 estão detalhadas as fases e quais populações de microrganismos foram analisadas.

Tabela 4.6: Quantificação de microrganismos nas diferentes etapas

\begin{tabular}{cc}
\hline Etapa & População de Microrganismos \\
\hline III e IV & Bactérias Anaeróbias Totais \\
IV & Bactérias Redutoras de Ferro \\
III e IV & Arquéias Metanogênicas \\
\hline
\end{tabular}

O procedimento consistiu na inoculação dos microrganismos provenientes do reator, em meio de cultura (ANGELIDAKI et al., 1990), descrito na Tabela 4.3, solução de 
vitaminas (Tabela 4.4) (TOUZEL \& ALBAGNAC, 1983) e LAS. O procedimento de retirada de amostras da região do leito e copo está detalhado no item 4.9.

Portanto, para quantificação das bactérias anaeróbias totais e arquéias metanogênicas foi utilizado como meio de cultura para o NMP o mesmo meio utilizado na alimentação do reator.

Todavia, para quantificação das bactérias redutoras de ferro foi utilizando, além dos mesmos reagentes da alimentação, EDTA férrico sal sódico, segundo metodologia adaptada de Gould et al. (2002).

Os procedimentos detalhados a seguir foram os mesmos para a quantificação de todas as populações, sendo apenas diferente a metodologia de detecção e o meio de incubação. A metodologia do NMP foi divida em duas partes. Primeira, diluição seriada da amostra em água de diluição e segunda, inoculação em meio de cultura específico.

\subsection{1 Água de diluição}

Para a preparação da água de diluição foram necessárias duas soluções descritas na Tabela 4.7.

Tabela 4.7: Soluções para água de diluição

\begin{tabular}{ccc}
\hline Solução para Água de Diluição & Reagente & Volume* \\
\hline $\mathbf{1}$ & $\mathrm{K}_{2} \mathrm{HPO}_{4}(0,2 \mathrm{M})$ & $1 \mathrm{~mL}$ \\
$\mathbf{2}$ & $\mathrm{KH}_{2} \mathrm{PO}_{4}(0,2 \mathrm{M})$ & $0,25 \mathrm{~mL}$ \\
\hline
\end{tabular}

*q.s.p 250mL de água destilada anaeróbia

Primeiramente, foi preparada a água anaeróbia. Para tanto, $300 \mathrm{~mL}$ de água destilada foi transferida para erlenmeyer e submetida ao aquecimento até entrar em ebulição. A seguir, essa água foi resfriada, durante 20 minutos, sob atmosfera de $\mathrm{N}_{2}$ (100\%), acoplandose uma mangueira e pipeta ao sistema de distribuição de gás. Logo em seguida, essa água anaeróbia foi utilizada para preparar a solução de diluição. Dessa forma, as soluções 1 e 2 foram adicionadas em frasco apropriado e o volume finalizado com essa água anaeróbia, como descrito na Tabela 4.7.

A seguir, iniciou-se a distribuição da água de diluição nos frascos. Exatamente 9,0 mL dessa água foram transferidos para frascos de antibióticos $(30 \mathrm{~mL})$ com o auxílio de um pipetador automático. Após a transferência os frascos foram submetidos à atmosfera de $\mathrm{N}_{2}$ 
(100\%) por 1 minuto, tampados e lacrados. Todo esse material foi esterilizado em autoclave a $121^{\circ} \mathrm{C}$ e 1 atm durante 20 minutos.

\subsubsection{Meios de Cultura para o NMP}

A água utilizada para a preparação dos meios de cultura foi preparada seguindo o mesmo procedimento descrito anteriormente, umas vez que, faz se necessário utilizar água anaeróbia.

O meio de cultura para o NMP consistiu nos mesmos reagentes e concentrações utilizados na alimentação do reator, referente a etapa em que foi retirada a amostra, acrescentado EDTA férrico sal sódico $(1,84 \mathrm{~g} / \mathrm{L})$ apenas no meio do NMP das bactérias redutoras de ferro. O procedimento para a preparação do meio de cultura foi o mesmo em todos os casos.

O meio foi esterilizado por filtração em membrana $(0,22 \mu \mathrm{m})$ através de sistema Millipore previamente esterilizado em autoclave a $121^{\circ} \mathrm{C}, 1 \mathrm{~atm}$, durante 20 minutos. Após a filtração, o meio foi submetido à atmosfera de $\mathrm{N}_{2}(100 \%)$ durante 20 minutos e, posteriormente, a atmosfera de $\mathrm{N}_{2} / \mathrm{CO}_{2}(70 / 30 \%)$, por mais 20 minutos. A seguir foram transferidos $8,9 \mathrm{~mL}$ desse meio para frascos de antibiótico de $30 \mathrm{~mL}$, previamente, esterilizados. Os frascos foram fechados com tampa de butila e lacre de alumínio. Em todos os frascos de contagem, anteriormente a inoculação foi adicionado $0,1 \mathrm{~mL}$ de solução redutora de sulfeto de sódio (5\%) (Sakamoto, 1996).

\subsubsection{Inoculação}

Volume conhecido de lodo granulado $(10 \mathrm{~mL})$ foi desmanchado com auxílio de cadinho e almofariz (Sakamoto, 2010 - protocolo FINEP). Posteriormente, essa amostra foi transferida para frasco de antibiótico com tampa de butila acrescido de $5 \mathrm{~g}$ de pérolas de vidro previamente esterilizada em autoclave. $\mathrm{O}$ frasco com o lodo granulado mais as pérolas de vidro foi agitado manualmente em ângulo de $45^{\circ}$, durante 20 minutos para completa desagregação celular (VAZOLLER,1995).

A seguir foi realizada a diluição seriada da amostra. Para tanto, foi transferido $1 \mathrm{~mL}$ da amostra em $9 \mathrm{~mL}$ de água diluição preparado previamente. A partir dessa diluição, mais 1 $\mathrm{mL}$ foi retirado e transferido para outro frasco de diluição contendo $9 \mathrm{~mL}$, e assim sucessivamente, até a diluição $10^{-20}$ (Figura 4.4). A transferência de amostra foi realizada com seringa estéril de $1 \mathrm{~mL}$. 


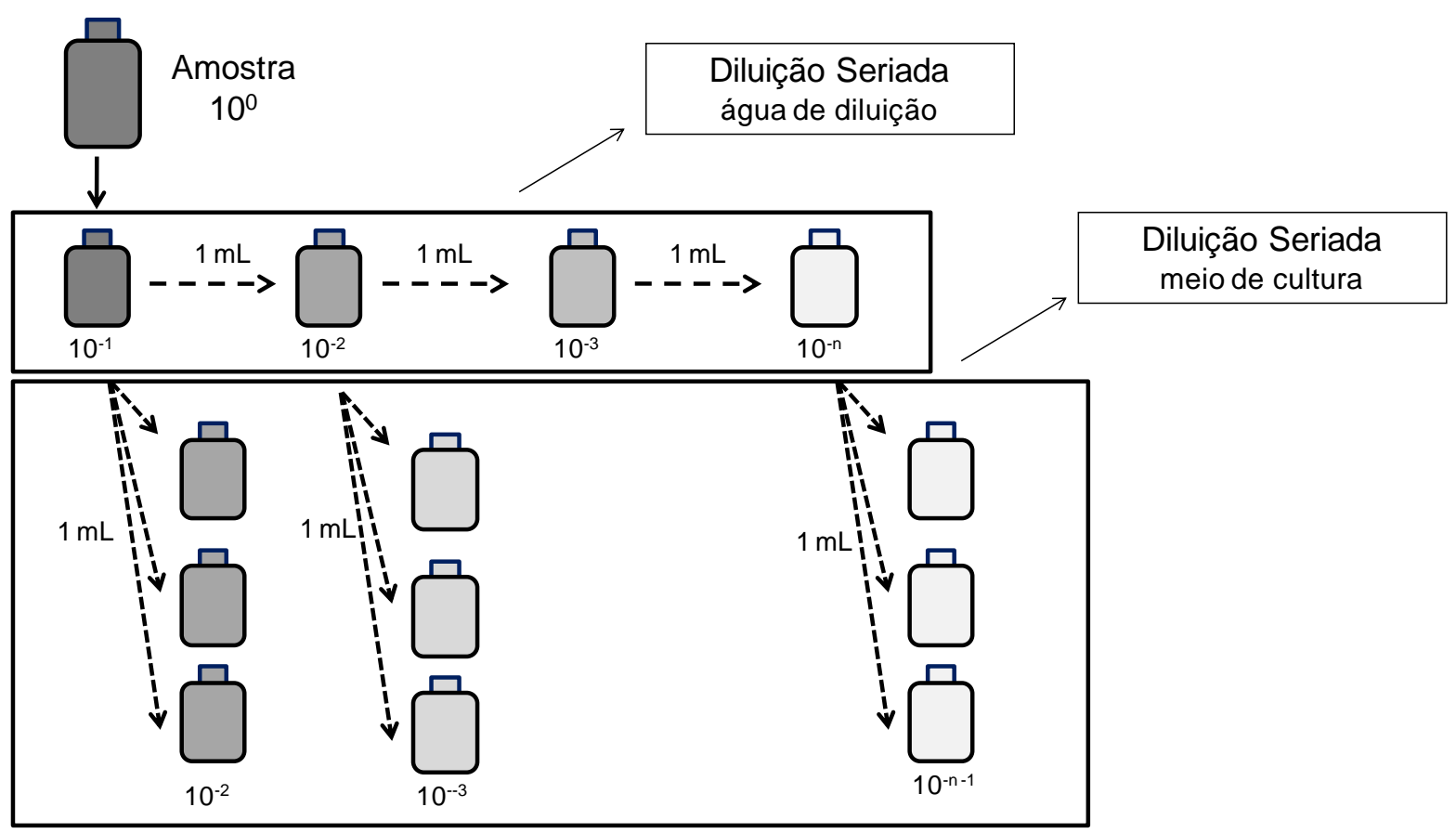

Figura 4.4: Esquema da diluição seriada utilizando água de diluição e inoculção em meio de cultura

A partir da diluição seriada com água de diluição foi realizada a inoculação em meio de cultura como detalhado anteriormente. Dessa forma, $1 \mathrm{~mL}$ de amostra do frasco de diluição foi inoculado em 9,0 mL de meio de cultura específico para cada população de microrganismos (Figura 4.4). A etapa de inoculação foi realizada em triplicata. Os frascos de contagem (NMP) foram incubados a $30^{\circ} \mathrm{C} \pm 1^{\circ} \mathrm{C}$ durante 30 dias.

\subsubsection{Leitura do NMP}

A leitura do NMP foi realizada conforme descrito na Tabela 4.8. As bactérias anaeróbias totais foram detectadas pela turvação do meio nas diferentes diluições. As arquéias metanogênicas foram quantificadas pela detecção de metano em cada frasco de contagem, por meio de análise de cromatografia gasosa. As bactérias redutoras de ferro pela presença de Fe II no meio a partir da reação com ferrozina (Gould et al., 2002).

Tabela 4.8: Formas de detecção para as diferentes populações microbianas

\begin{tabular}{lc}
\hline População Microbiana & Detecção \\
\hline Bactérias Anaeróbias Totais & Turvação do Meio \\
Arquéias Metanogênicas & Presença de Metano \\
Bactérias Redutoras de Ferro & Reação com Ferrozina $0,1 \%$ p/v (coloração rosada) \\
\hline
\end{tabular}


Os resultados positivos e negativos dos grupos microbianos em cada diluição serviram de base para estimar o número mais provável com base na tabela padrão de probabilidade (APHA, 2005). Após a consulta a tabela foi utilizada a fórmula abaixo para calcular NMP/100mL e, por conseguinte, NMP/gSTV.

$$
\text { NMP (tabela APHA) } \left.\times \frac{10}{10^{y}}=\text { NMP (células } / 100 \mathrm{~mL}\right)
$$

Sendo:

y = menor diluição da série de combinações selecionadas

\subsection{Análise Qualitativa da Diversidade Microbiana}

Para análise filogenética da diversidade microbiana do reator EGSB foi utilizado o seqüenciamento do RNAr 16S. Segundo a literatura apenas microrganismos pertencentes ao Domínio Bacteria estão relacionados à remoção do LAS. Dessa forma foi utilizado apenas primers específicos para esse Domínio. Na Figura 4.5 estão detalhadas as etapas necessárias até o seqüenciamento das amostras.

As amostras foram retiradas de dois locais do reator, leito e copo, em duplicata. A amostra do leito do reator foi obtida de forma composta, para tanto, $5 \mathrm{~mL}$ foram retirados de cada ponto de amostragem distribuído ao longo do leito do reator (6 pontos no total). Em seguida, a amostra foi homogeneizada e armazenada. Na amostra da extremidade superior do reator (copo) foram retirados $30 \mathrm{~mL}$ com auxílio de uma seringa. Para tanto, a região superior do reator foi aberta para facilitar a coleta da biomassa depositada nessa região. Em seguida, a amostra foi homogeneizada e armazenada. Em cada situação seguiu-se os procedimentos sintetizados na Figura 4.5. 


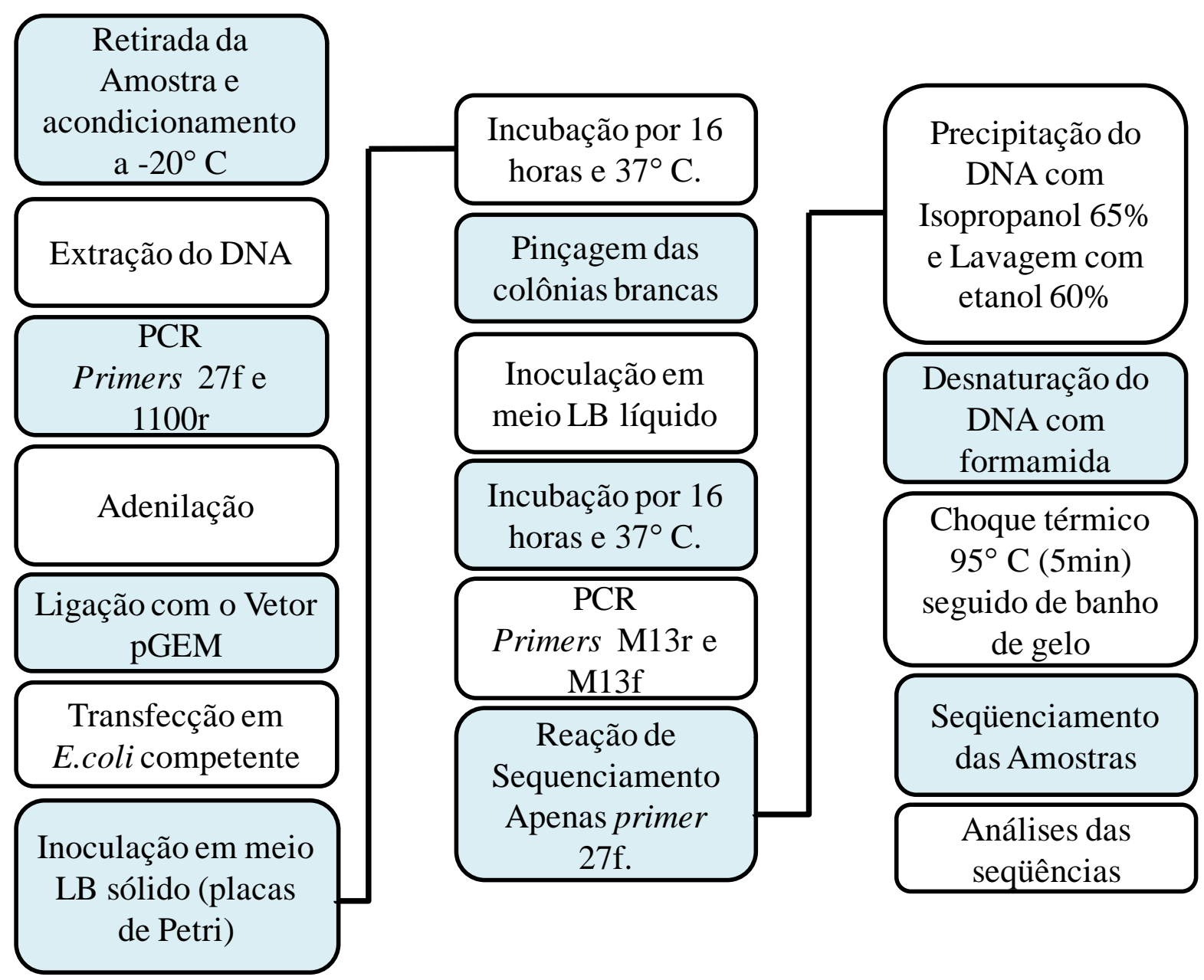

Figura 4.5: Sequiência de passos até o seqüenciamento das amostras do reator

\subsubsection{Acondicionamento das amostras}

$\mathrm{O}$ acondicionamento das amostras foi realizado da seguinte forma:

a) As amostras do copo e do leito foram colocadas em tubo Falcon de $15 \mathrm{~mL}$ estéril,

b) Centrifugou-se as amostras a $6.000 \mathrm{rpm}$ por 10 minutos a temperatura de $4^{\circ} \mathrm{C}$,

c) Adicionou-se $5 \mathrm{~mL}$ de tampão fosfato (PBS) para lavagem do material,

d) Descartou-se o sobrenadante,

e) Repetiu-se o procedimento "c" e "d" por mais uma vez,

f) As amostras foram armazenadas $\mathrm{a}-20^{\circ} \mathrm{C}$.

\subsubsection{Extração do DNA}

O DNA foi extraído usando fenol/clorofórmio segundo metodologia descrita em Griffiths et al., (2000) com alguns modificações em virtude do material biológico em questão. 


\subsubsection{Caracterização do domínio Bacteria}

Para caracterização apenas do domínio Bacteria foram utilizados primers específicos descritos por Lane, (1991), 27F-1100R (Tabela 4.9) nas condições apresentadas na Tabela 4.10 .

Tabela 4.9: Primers para amplificação da região $16 \mathrm{~S}$ do domínio Bacteria

\begin{tabular}{cc}
\hline Primers & Seqüências $\left(\mathbf{5}^{\prime} \rightarrow\right.$ 3' $\left.^{\prime}\right)$ \\
\hline $27 \mathrm{~F}$ & 5'- AGA GTT TGA TCC TGG CTC AG-3' \\
$1100 \mathrm{R}$ & 5'-AGG GTT GCG CTC GTT G-3' \\
\hline Lane, 1991 &
\end{tabular}

Tabela 4.10: Programação do termociclador para os primers do domínio Bacteria

\begin{tabular}{cccccc}
\hline $\begin{array}{c}\mathbf{N}^{\circ} \text { de } \\
\text { ciclos }\end{array}$ & $\begin{array}{c}\text { Desnaturação } \\
\text { inicial }\end{array}$ & Desnaturação & Anelamento & Extensão & Resfriamento \\
\hline \multirow{2}{*}{30} & $94{ }^{\circ} \mathrm{C}$ & $94{ }^{\circ} \mathrm{C}$ & $55^{\circ} \mathrm{C}$ & $72^{\circ} \mathrm{C}$ & $4{ }^{\circ} \mathrm{C}$ \\
& $5 \mathrm{~min}$ & $45 \mathrm{~s}$ & $45 \mathrm{~s}$ & $105 \mathrm{~s}$ & $\infty$ \\
\hline
\end{tabular}

Na Tabela 4.11 estão detalhados os reagentes e concentrações utilizadas para reação em cadeia da polimerase (PCR).

Tabela 4.11: Soluções para amplificação usando primers 27F e 1100R

\begin{tabular}{ccc}
\hline Reagentes & Concentração & $\begin{array}{c}\text { Quantidade } \\
\text { para 1 amostra }(\boldsymbol{\mu L})\end{array}$ \\
\hline $\mathrm{H}_{2} \mathrm{O}$ ultrapura & - & 3,0 \\
Tampão PCR Invitrogen ${ }^{2}$ & $10 \mathrm{X}$ & 5,0 \\
$\mathrm{MgCl}_{2}$ & $50 \mathrm{mM}$ & 1,5 \\
dNTP (cada base nitrogenada) & $2 \mathrm{mM}$ & 5,0 \\
Primer 27F & $100 \mathrm{pmol} / \mu \mathrm{L}$ & 0,5 \\
Primer 1100R & $100 \mathrm{pmol} / \mu \mathrm{L}$ & 0,5 \\
Taq DNA Polimerase Invitrogen ${ }^{2}$ & $5 \mathrm{U} / \mu \mathrm{L}$ & 0,5 \\
Amostra & $100 \mathrm{ng}$ & 2,0 \\
\hline
\end{tabular}

Previamente a clonagem, procedeu-se à purificação do produto de PCR utilizando o Kit Illustra GFX PCR DNA and Gel Band Purification e as especificações detalhadas no manual. 


\subsubsection{Clonagem, Amplificação do DNA plasmidial e Seqüenciamento}

A clonagem em células competentes de E.coli, foi realizada utilizando os produtos de PCR purificados e 50ng do vetor plasmidial pGEM Easy Vector System I. Primeiramente, procedeu-se a adenilação dos fragmentos, utilizando $3 \mu \mathrm{L}$ do produto de PCR purificado, 1 $\mu \mathrm{L}$ de tampão PCR (10X) com $\mathrm{MgCl}_{2}, 1 \mu \mathrm{L}$ de dATP $(5 \mathrm{mM}), 1 \mu \mathrm{L}$ de Taq DNA polimerase e 4,0 $\mu \mathrm{L}$ de água ultra purificada estéril. A incubação foi a $70^{\circ} \mathrm{C}$ por 30 minutos.

Para a reação de ligação do DNA ao vetor $p G E M$ foram utilizados $5,0 \mu \mathrm{L}$ de $2 \mathrm{x}$ Rapid Ligation Buffer, $1 \mu \mathrm{L}$ de Vector pGEM-T easy (50ng), $2 \mu \mathrm{L}$ de produto de PCR adenilado e 1 $\mu \mathrm{L}$ de T4 DNA ligase (3 weiss units $/ \mu \mathrm{L}$ ). Misturaram-se os reagentes cuidadosamente e incubou-se por 1 hora a temperatura ambiente $\left(23\right.$ a $\left.25^{\circ} \mathrm{C}\right)$. Logo em seguida, incubou-se por 16 horas a $4^{\circ} \mathrm{C}$.

Para a transformação da E.coli, foram utilizados $3 \mu \mathrm{L}$ do produto de ligação. Estes foram cuidadosamente homogeneizados com E. coli competente que estava em banho de gelo. Logo em seguida, foram transferidos para banho maria a $42^{\circ} \mathrm{C}$ por 50 segundos, sem agitação. Novamente, transferidas para banho de gelo por 2 minutos. Adicionou-se $200 \mu \mathrm{L}$ meio Luria-Bertani (LB) (Tabela 4.12) à temperatura ambiente e incubou-se por 90 minutos a $37^{\circ} \mathrm{C}$ com agitação de $150 \mathrm{rpm}$.

Tabela 4.12: Componentes do Meio Luria-Bertani (LB)

\begin{tabular}{cc}
\hline Componentes & $\begin{array}{c}\text { Concetração } \\
(\mathbf{g} / \mathbf{L})\end{array}$ \\
\hline Triptona & 10 \\
Extrato de Levedura & 5 \\
Cloreto de Sódio & 5 \\
Ágar & 15 \\
\hline
\end{tabular}

Decorrido esse período, $150 \mu \mathrm{L}$ do material transformado foram transferidos para uma placa de Petri contendo aproximadamente $25 \mathrm{~mL}$ de LB sólido, previamente preparado, e incubado a $37^{\circ} \mathrm{C}$ por 24 horas. Além do meio $\mathrm{LB}$ sólido, outros reagentes foram adicionados (Tabela 4.3). 
Tabela 4.13: Componentes do meio LB para crescimento da E.coli transformada

\begin{tabular}{ccc}
\hline Componentes & $\begin{array}{c}\text { Concentração } \\
(\mathbf{m g} / \mathbf{L})\end{array}$ & $\begin{array}{c}\text { Volume } \\
(\mathbf{q . s . p} \text { 50mL de LB) }\end{array}$ \\
\hline Xgal & 40 & $64 \mu \mathrm{L}$ \\
IPTG & 23 & $80 \mu \mathrm{L}$ \\
Ampicilina & 50 & $30 \mu \mathrm{L}$ \\
\hline
\end{tabular}

Após 24 horas as placas foram retiradas da estufa e colocadas na geladeira a $4^{\circ} \mathrm{C}$ por 1 hora para intensificação da cor das colônias azuis. Com o auxílio de uma ponteira apenas as colônias brancas foram pinçadas e transferidas para meio LB líquido $(5 \mathrm{~mL})$ contendo $3 \mu \mathrm{L}$ de ampicilina $(50 \mathrm{mg} / \mathrm{L})$ e incubadas por 16 horas a $37^{\circ} \mathrm{C}$ em câmara de germinação com agitação de 150 rpm.

Ultrapassada às 16 horas de incubação, os tubos que apresentaram turvação do meio foram selecionados para etapa seguinte. Essa etapa consistiu na transferência para tubo apropriado de parte do meio turvo. Esse material foi centrifugado a $10.000 \mathrm{rpm}$ à $4^{\circ} \mathrm{C}$.

A etapa de extração do DNA plasmidial não foi realizada. Ao invés disso, foi utilizado o par de primers descrito por Chun et al. (1995), detalhado na Tabela 4.14 para amplificação do DNA plasmidial.

Tabela 4.14: Primers específicos para amplificação do DNA plasmidial

\begin{tabular}{cc}
\hline Primers & Seqüências $\left(5^{\prime} \rightarrow\right.$ 3' $\left.^{\prime}\right)$ \\
\hline M13F & 5'-CGC CAG GGT TTT CCC AGT CAC GAC-3' \\
M13R & 5'-TTT CAC ACA GGA AAC AGC TAT GAC-3'
\end{tabular}
Chun, 1995

Os componentes dessa PCR estão descritos na Tabela 4.11 nas condições apresentadas na Tabela 4.15.

Tabela 4.15: Programação do termociclador para amplificação do DNA plasmidial

\begin{tabular}{cccccc}
\hline $\begin{array}{c}\mathbf{N}^{\circ} \text { de } \\
\text { ciclos }\end{array}$ & $\begin{array}{c}\text { Desnaturação } \\
\text { inicial }\end{array}$ & Desnaturação & Anelamento & Extensão & Resfriamento \\
\hline \multirow{2}{*}{30} & $94{ }^{\circ} \mathrm{C}$ & $94{ }^{\circ} \mathrm{C}$ & $60{ }^{\circ} \mathrm{C}$ & $72{ }^{\circ} \mathrm{C}$ & $4{ }^{\circ} \mathrm{C}$ \\
& $3 \mathrm{~min}$ & $20 \mathrm{~s}$ & $20 \mathrm{~s}$ & $1,5 \mathrm{~min}$ & $\infty$ \\
\hline
\end{tabular}

A amplificação do DNA plasmidial foi verificada por eletroforese em gel de agarose. Apenas as amostras que apresentaram bandas por volta de $800 \mathrm{bp}$ foram selecionadas para etapa seguinte. 
A etapa seguinte consistiu na purificação desse produto de PCR (M13f e M13r) com o Kit illustra GFX PCR DNA and Gel Band Purification visando o seqüenciamento das amostras. Para tanto, foi utilizado Big Dye Terminator (Applied Biosystem ${ }^{\circledR}$ ) com nucleotídeos marcados. Os reagentes da reação de seqüenciamento e volume estão mostrados na Tabela 4.16, nas condições do termociclador apresentadas na Tabela 4.17.

Tabela 4.16: Soluções para reação de seqüenciamento usando primer 27F

\begin{tabular}{cc}
\hline Componetes & Volume $(\mu \mathrm{L})$ \\
\hline Big Dye & 1 \\
Save \$ & 1 \\
Primer 27F 10p/mol & 3 \\
Amostra (produto de PCR M13) purificado & 2 \\
Água ultra purificada & 3 \\
\hline
\end{tabular}

Tabela 4.17: Programação do termociclador para reação de seqüenciamento

\begin{tabular}{cccccc}
\hline $\begin{array}{c}\mathbf{N}^{\circ} \text { de } \\
\text { ciclos }\end{array}$ & $\begin{array}{c}\text { Desnaturação } \\
\text { inicial }\end{array}$ & Desnaturação & Anelamento & Extensão & Resfriamento \\
\hline \multirow{2}{*}{35} & $94{ }^{\circ} \mathrm{C}$ & $94{ }^{\circ} \mathrm{C}$ & $50{ }^{\circ} \mathrm{C}$ & $60{ }^{\circ} \mathrm{C}$ & $4{ }^{\circ} \mathrm{C}$ \\
& $2 \mathrm{~min}$ & $15 \mathrm{~s}$ & $15 \mathrm{~s}$ & $2 \mathrm{~min}$ & $\infty$ \\
\hline
\end{tabular}

Com o objetivo de retirar o excesso de moléculas fluorescentes foi realizado a precipitação do DNA com isopropanol 65\%. Dessa forma, foram adicionados $40 \mu \mathrm{L}$ de isopropanol $65 \%$ nos tubos eppendorff onde seriam realizadas as reações de seqüenciamento. Logo em seguida, centrifugou-os por 30 minutos a $20^{\circ} \mathrm{C}$ a $14.000 \mathrm{rpm}$. Ultrapassado os 30 minutos, o excesso de isopropanol foi retirado pela inversão do tubo seguido da adição de $200 \mu \mathrm{L}$ de etanol $60 \%$. Novamente, centrifugou-se nas mesmas condições anteriores, porém por apenas 5 minutos. As amostras foram mantidas em temperatura ambiente $\left(23^{\circ} \mathrm{C}\right.$ a $\left.25^{\circ} \mathrm{C}\right)$ por 16 horas até a evaporação total do etanol.

Aos pellets foram adicionados $15 \mu \mathrm{L}$ de formamida seguido de choque térmico $\left(94^{\circ} \mathrm{C}\right.$ por 5 minutos e $4^{\circ} \mathrm{C}$ por tempo indefinido). A leitura das seqüências de nucleotídeos foi realizada em analisador automático de DNA modelo ABI PRISM 310 (Applied Biosystems $\left.{ }^{\circledR}\right)$.

\subsubsection{Análise das Seqüencias de DNA}

Para as análises das sequiências de DNA foram utilizados os programas detalhado na Tabela 4.18. 
As seqüências foram inspecionadas utilizando o programa SeqMan para o polimento e retirada de regiões com baixa qualidade de sinal. Concomitantemente, foi construído um banco de dados com essas seqüências analisadas no formato FASTA.

Esse banco de dados foi confrontado com o banco de dados do RDP-project (Ribossomal Database Project) utilizando o RDP-classifier para comparar cada seqüência e RDP Library compare para comparar bibliotecas de RNAr 16S.

Logo em seguida, as amostras foram alinhadas utilizando o programa ClustalW 2.0. Esse procedimento é necessário para utilizar as demais ferramentas. $\mathrm{O}$ alinhamento ocorreu juntando os clones da região do copo e os clones da região do leito. Esse arquivo foi inserido no programa Phylip DNAdist (algoritmo de Kimura) para elaboração da matriz de distancia evolutiva que é requisito para utilização do programa DOTUR.

Inserida a matriz de distancia evolutiva no programa DOTUR foi possível estabelecer as UTOs e elaborar a curva de rarefação com diferentes distâncias evolutivas. A árvore filogenética foi realizada utilizando o programa MEGA método Neighbor-Joining, $e$ bootstrap de 100 amostragens.

Tabela 4.18: Programas utilizados para analisar as seqüências de DNA

\begin{tabular}{|c|c|c|}
\hline Programa & Função & Onde localizar \\
\hline Seqman & $\begin{array}{l}\text { Polimento das sequências } \\
\text { de DNA com retirada das } \\
\text { extremidades em função da } \\
\text { qualidade do } \\
\text { seqüenciamento }\end{array}$ & $\begin{array}{l}\text { http://www.dnastar.com/t-sub- } \\
\text { products-lasergene-seqmanpro.aspx }\end{array}$ \\
\hline $\begin{array}{l}\text { RDP classifier e } \\
\text { RDP Library } \\
\text { Compare }\end{array}$ & $\begin{array}{l}\text { Classificação inicial das } \\
\text { seqüuências e Comparação } \\
\text { das bibliotecas, } \\
\text { respectivamente }\end{array}$ & $\begin{array}{l}\text { http://rdp.cme.msu.edu/classifier/classi } \\
\text { fier.jsp } \\
\text { http://rdp.cme.msu.edu/comparison/co } \\
\text { mp.jsp }\end{array}$ \\
\hline ClustalW 2.0 & $\begin{array}{l}\text { Alinhamento das } \\
\text { seqüências de DNA }\end{array}$ & $\begin{array}{l}\text { http://mobyle.pasteur.fr/cgi- } \\
\text { bin/portal.py?form=dnadist }\end{array}$ \\
\hline Phylip DNAdist & $\begin{array}{l}\text { Construção da matriz de } \\
\text { distancia evolutiva }\end{array}$ & $\begin{array}{l}\text { http://mobyle.pasteur.fr/cgi- } \\
\text { bin/portal.py?form=dnadist }\end{array}$ \\
\hline DOTUR & \begin{tabular}{|lr} 
Definição das & UTOs e \\
Curva de & Rarefação \\
observando & varias \\
distancias evolutivas
\end{tabular} & $\begin{array}{l}\text { http://www.plantpath.wisc.edu/fac/joh/ } \\
\text { dotur/downloads.html }\end{array}$ \\
\hline MEGA & $\begin{array}{l}\text { Elaboração da árvore } \\
\text { filogenética }\end{array}$ & http://www.megasoftware.net/ \\
\hline
\end{tabular}




\section{RESULTADOS E DISCUSSÃO}

\subsection{Remoção de Matéria Orgânica}

Os co-substratos utilizados nesse trabalho foram metanol e etanol. Ambos são compostos facilmente degradáveis pela comunidade microbiana presente no reator. A utilização de metanol teve por finalidade favorecer o crescimento preferencial de arquéias metanogênicas, especificamente Methanosarcina (JETTEN et al., 1991). Tais microrganismos usam preferencialmente os seguintes substratos para a metanogênese: hidrogênio, dióxido de carbono, metanol, metilaminas e acetato (GUJER \& ZEHNDER, 1983).

Arquéias metanogênicas, semelhantes a Methanosaeta, também, fazem parte da comunidade microbiana de grânulos de reatores UASB e EGSB. Tais arquéias metanogênicas apresentam maior afinidade para o acetato $(\mathrm{Ks}=0.46 \mathrm{mM})$ em relação a Methanosarcina (Ks=3-5 mM), todavia, a Methanosaeta cresce mais lentamente que Methanosarcina (GUJER \& ZEHNDER, 1983). Huser et al., (1982) relataram que Methanosarcina barkeri e Methanosarcina mazei têm tempos de duplicação de aproximadamente 24 horas, enquanto, Methanosaeta pode duplicar a sua população em 3,5 e até 9 dias.

Desse modo, essas arquéias metanogênicas acetoclásticas contribuem significativamente na utilização do ácido acético, evitando assim, seu acúmulo, o qual interfere na remoção do LAS, uma vez que está relacionado com a estabilidade do reator, de acordo, com os dados obtidos por Lobner et al.(2005).

Além disso, segundo Abboud et al. (2007), co-substratos são necessários para os microrganismos responsáveis pela degradação do LAS permanecerem com atividade enzimática estável. Portanto, a utilização de metanol e etanol é apropriada durante o primeiro contato das as bactérias com o LAS (Schörberl, 1985).

Na Tabela 5.1 e Figura 5.1 estão sintetizados os valores médios de DQO afluente, efluente e eficiência de remoção no reator EGSB. 
Tabela 5.1: Síntese dos resultados de DQO

\begin{tabular}{|c|c|c|c|c|}
\hline \multirow{2}{*}{ Parâmetro } & \multicolumn{4}{|c|}{ Etapas } \\
\hline & I & II & III & IV \\
\hline \multicolumn{5}{|l|}{ DQO } \\
\hline Afluente $(\mathrm{mg} / \mathrm{L})$ & $573 \pm 140$ & $812 \pm 92$ & $856 \pm 82$ & $798 \pm 78$ \\
\hline Efluente (mg/L) & $11 \pm 12$ & $30 \pm 25$ & $30 \pm 17$ & $45 \pm 25$ \\
\hline Remoção (\%) & $97,6 \pm 2,9$ & $96,3 \pm 3,4$ & $96,7 \pm 1,8$ & $94,2 \pm 3,8$ \\
\hline Carga Orgânica Aplicada (kgDQO/d) & $0,8 \pm 0,08$ & $0,8 \pm 0,12$ & $0,6 \pm 0,03$ & $0,8 \pm 0,03$ \\
\hline TDH $(\mathrm{h})$ & $32,2 \pm 10,2$ & $32,0 \pm 15,1$ & $26,0 \pm 4,5$ & $32,0 \pm 4,5$ \\
\hline Duração (dias) & 48 & 52 & 111 & 74 \\
\hline
\end{tabular}

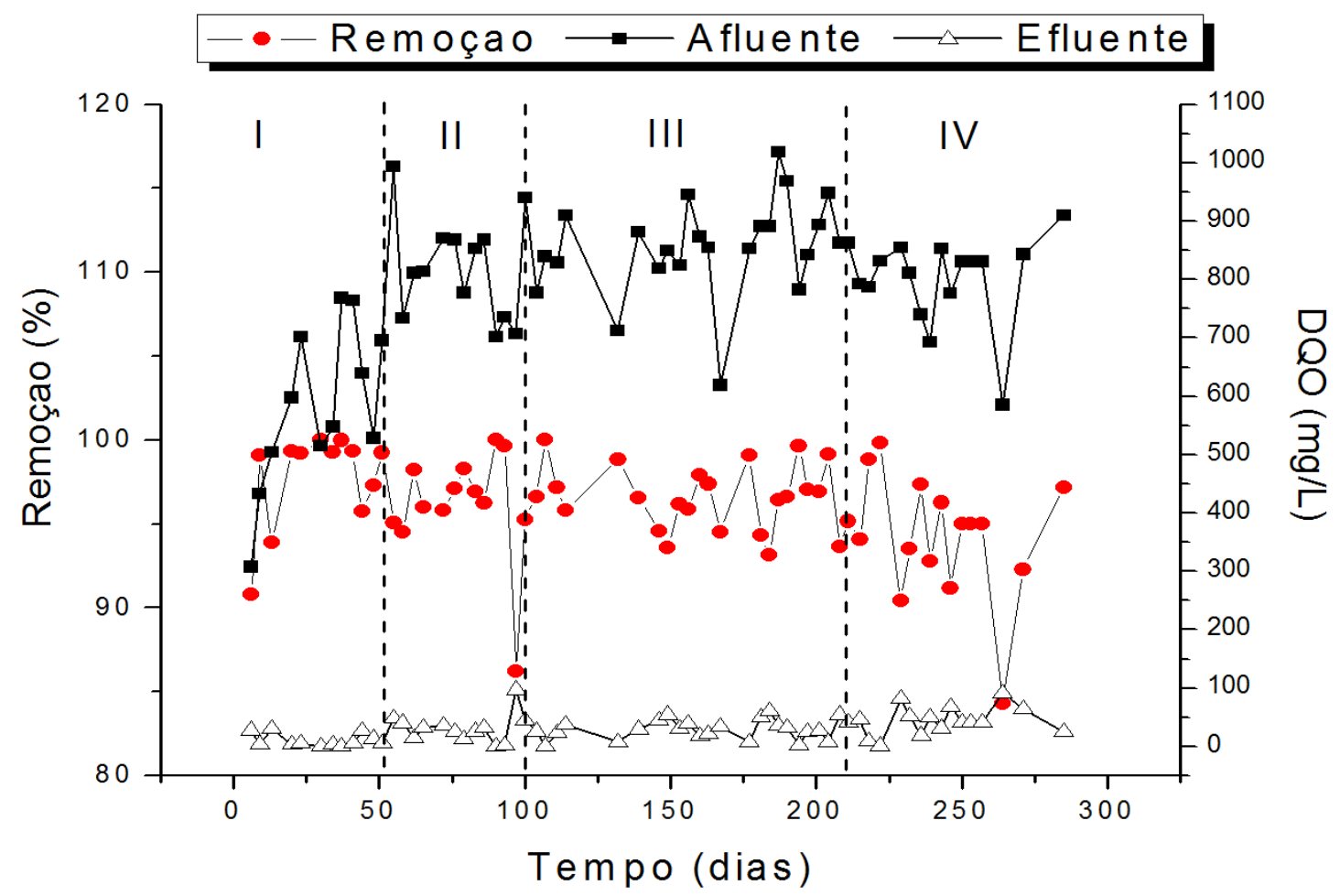

Figura 5.1: Variação temporal da matéria orgânica

Na Etapa I, com duração de 48 dias e TDH de 32,2 $\pm 10,2$ horas foi obtida DQO média

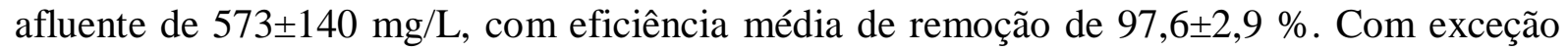
do primeiro dia, em que a remoção foi de $90 \%$, em todos os demais dias obteve-se valor superior a 95\%. Isso demonstrou rápida adaptação da biomassa às condições hidráulicas do reator e a composição dos substratos orgânicos.

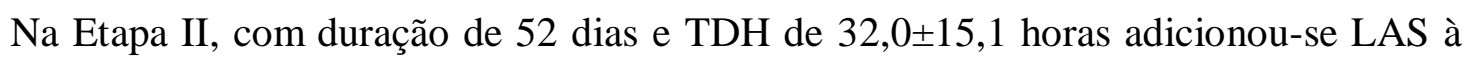

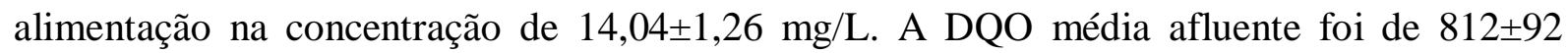


mg/L com eficiência de remoção de 96,3ะ3,4\%. Nessa etapa, verificou-se que mesmo com a adição de LAS, a remoção de DQO não foi alterada, apresentando valores próximos aos da Etapa I.

Segundo, Garcia et al. (2006), a concentração e a distribuição dos homólogos da molécula de LAS apresentam relação direta com a toxicidade desse surfactante. Segundo esses autores, $14 \mathrm{mg} / \mathrm{L}$ de LAS, na fase líquida foi considerado tóxico para os microrganismos anaeróbios, uma vez que reduziu em $50 \%$ a produção de biogás.

Entretanto, assim como nesse trabalho, outros autores não tiveram a remoção de DQO afetada com a adição de LAS (DUARTE et al., 2008; DE OLIVEIRA et al., 2009; DE OLIVEIRA et al., 2010a). Um dos motivos que pode explicar tal fato é que Garcia et al. (2006) realizaram os testes em reator de batelada $(250 \mathrm{~mL})$, com proporção gás/líquido de 3:7, enquanto, nos demais trabalhos citados os reatores foram operados em fluxo contínuo.

O maior tempo de contato da biomassa com o LAS pode prejudicar a atividade bacteriana (MOSCHE \& MEYER, 2002). Além disso, reatores de alta taxa, tais como, EGSB, suportam altas cargas orgânicas; ou seja, maiores que $15 \mathrm{kgDQO} / \mathrm{m}^{3}$.d. Todavia, a carga orgânica volumétrica desse trabalho foi de aproximadamente $0,8 \mathrm{kgDQO} / \mathrm{m}^{3}$.d. Portanto, uma carga orgânica volumétrica baixa comparada a potencialidade que esse reator pode suportar.

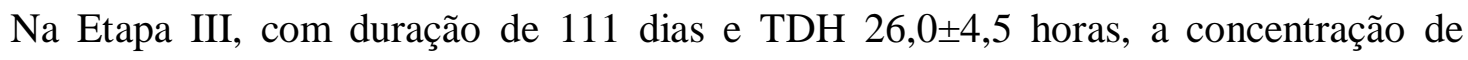
matéria orgânica afluente foi de $856 \pm 82 \mathrm{mg} / \mathrm{L}$, com eficiência média de remoção de $96,7 \pm 1,84 \%$. Os valores de DQO efluente foram de $30 \pm 17 \mathrm{mg} / \mathrm{L}$.

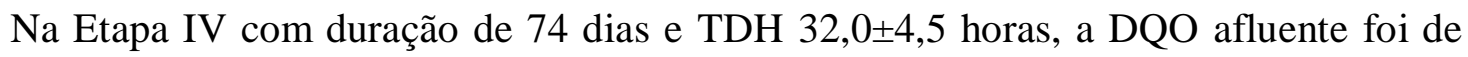
$798 \pm 78 \mathrm{mg} / \mathrm{L}$. Dentre todas as etapas, essa foi a que apresentou maior DQO efluente $45 \pm 25$ $\mathrm{mg} / \mathrm{L}$, resultando em eficiência de remoção de 94,2 $\pm 3,83 \%$. Diante desses resultados evidenciou-se tendência na redução da remoção de matéria orgânica, uma vez que nas outras etapas os valores médios de remoção foram acima de 96\%. Após 162 dias de operação, com $14 \mathrm{mg} / \mathrm{L}$ de LAS afluente é compreensível que a biomassa tenha sido prejudicada em virtude do longo tempo de exposição ao surfactante. Todavia, esse valor de remoção de matéria orgânica foi satisfatório, quando comparado com outras configurações de reatores anaeróbios usados na remoção de LAS.

\subsection{Remoção de LAS}

Na Tabela 4.2 estão resumidos os resultados obtidos com relação à concentração de LAS afluente, efluente, carga de LAS aplicada, remoção específica e eficiência de remoção 
no reator EGSB. A remoção de LAS pode ser analisada de duas formas: a partir da razão entre carga de LAS removida por carga de LAS aplicada e pela diferença entre a concentração afluente e efluente.

Na Figura 5.2 e Figura 5.3 encontram-se delineadas a variação temporal do LAS e variação temporal da relação carga de LAS removida por carga de LAS aplicada, respectivamente.

Tabela 5.2: Síntese dos resultados de LAS no reator EGSB

\begin{tabular}{|c|c|c|c|c|}
\hline & & Etapas & & \\
\hline LAS & I & II & III & IV \\
\hline Afluente $(\mathrm{mg} / \mathrm{L})$ & - & $14,04 \pm 1,2$ & $14,41 \pm 1,0$ & $13,33 \pm 3,2$ \\
\hline Efluente (mg/L) & - & $3,96 \pm 1,1$ & $7,51 \pm 1,0$ & $4,88 \pm 1,5$ \\
\hline Remoção (\%) & - & $73,6 \pm 5,6$ & $47,8 \pm 6,2$ & $63,6 \pm 6,17$ \\
\hline Carga Específica $\left(\mathrm{mg} \cdot \mathrm{gVS}^{-1} \cdot \mathrm{d}^{-1}\right)$ & - & $1,63 \pm 0,48$ & $2,61 \pm 0,54$ & $1,45 \pm 0,54$ \\
\hline Remoção Específica (mg.gVS $\left.{ }^{-1} \cdot \mathrm{d}^{-1}\right)$ & - & $1,22 \pm 0,42$ & $0,9 \pm 0,22$ & $0,97 \pm 0,14$ \\
\hline Remoção Específica/Carga Específica & - & 0,75 & 0,34 & 0,67 \\
\hline TDH (h) & $32,2 \pm 10,2$ & $32,0 \pm 15,16$ & $26,0 \pm 4,57$ & $32,0 \pm 4,57$ \\
\hline Duração (dias) & 48 & 52 & 111 & 74 \\
\hline
\end{tabular}

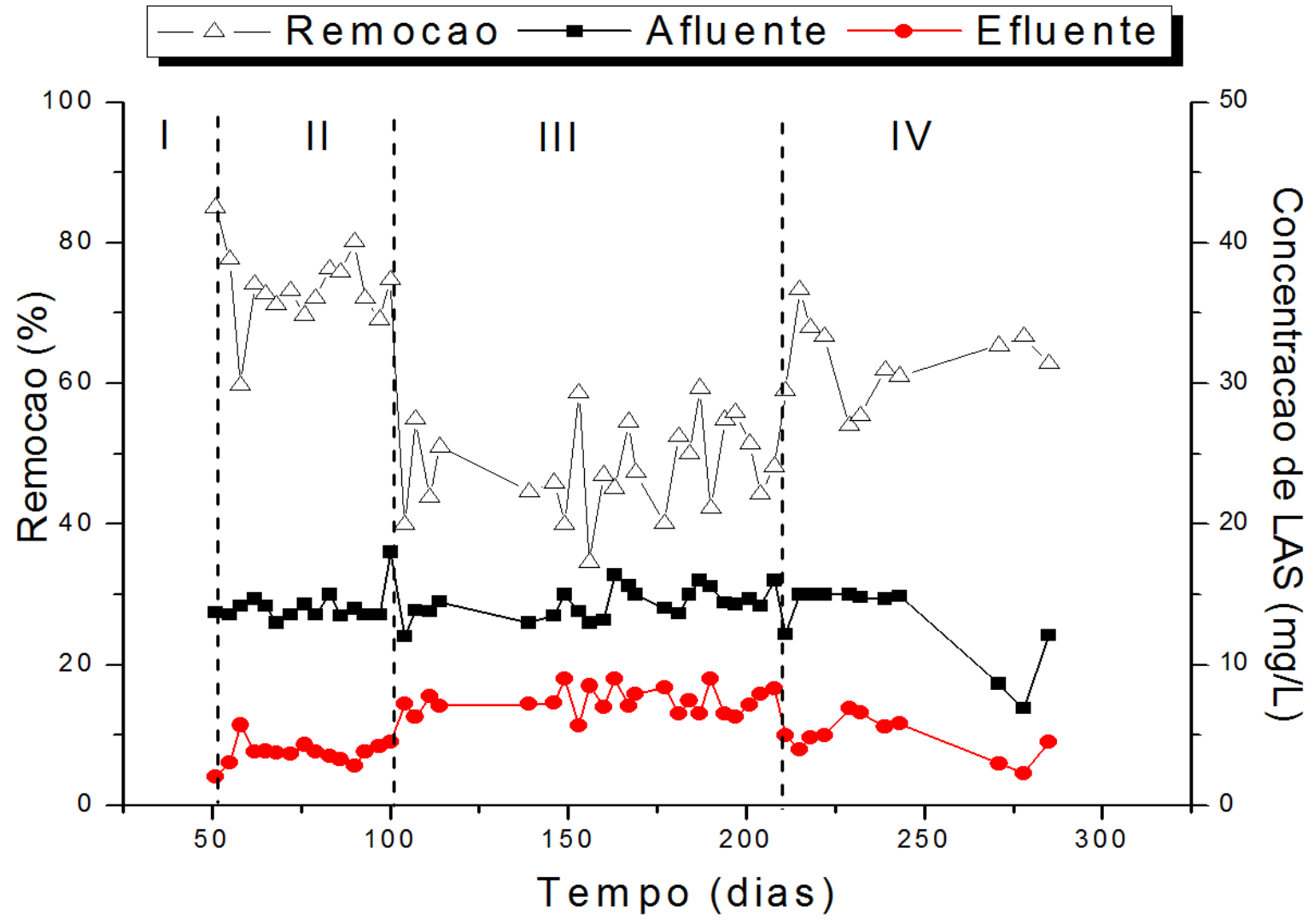

Figura 5.2: Variação temporal da concentração de LAS afluente, efluente e remoção. 


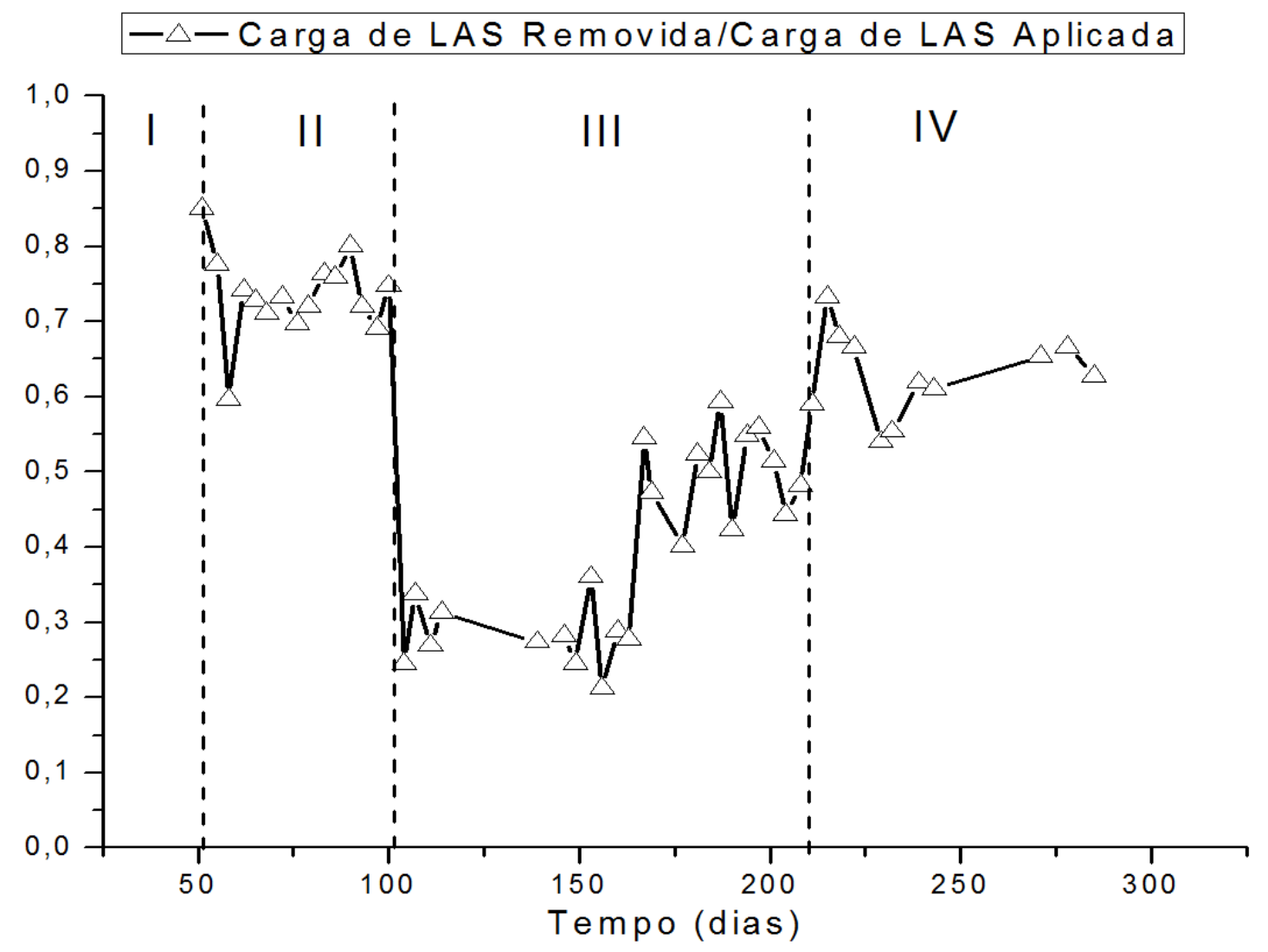

Figura 5.3: Relação carga de LAS removida por carga de LAS aplicada

As pequenas variações de LAS afluente durante a operação do reator EGSB estão relacionadas a precisão do método de determinação e a possíveis erros de amostragem, uma vez que, a coleta da amostra era realizada no frasco de alimentação contendo 5,5L. Contudo os desvios obtidos em cada parâmetro das etapas foram baixos.

A adição de LAS, ocorreu a partir da Etapa II, com concentração inicial de $14,04 \pm 1,2 \mathrm{mg} / \mathrm{L}$, não sendo de forma gradual, o que afetou negativamente a biomassa presente no reator. Tal fato, pode ser observado analisando os resultados de granulometria, sólidos (item 5.4) e NMP (item 5.9).

A remoção de surfactante de água residuária, em especial do LAS, pode ocorrer da seguinte forma: precipitação, adsorção e degradação biológica. Portanto, a palavra remoção de LAS está ligada a todos os processos acima citados, todavia, quando usamos a palavra degradação de LAS estamos nos referindo exclusivamente a processos biológicos.

A molécula de LAS apresenta características adsortivas acentuadas. Quanto maior a cadeia alquílica maior será o caráter hidrofóbico da molécula. Dessa forma, a concentração na fase líquida desse surfactante diminui significativamente com o aumento da cadeia alquílica 
(Garcia et al.,2005). Os homólogos da molécula de LAS que apresentam maior hidrofobicidade tendem a sofrer maior adsorção.

No $51^{\circ}$ dia de operação ficou evidente essa adsorção do LAS na biomassa granulada, ou seja, no primeiro dia de adição do LAS na alimentação. Nesse dia, a eficiência de remoção de LAS foi de 85\%, 11\%; ou seja, acima da média de remoção nessa etapa. No $55^{\circ}$ dia de operação a remoção foi de $77 \%$; ou seja, mais próximo a média $(73,6 \pm 5,6 \%)$ observada durante essa etapa. Provavelmente, o período de saturação da adsorção à biomassa granulada foi de cinco dias.

A Etapa II (TDH 32,0 $\pm 15,16$ horas) foi caracterizada por remoção de LAS de

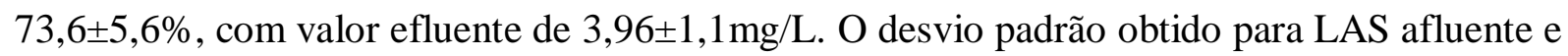
efluente foram baixos indicando reduzida oscilação na remoção do surfactante. A remoção específica média dessa etapa foi de $1,22 \pm 0,42 \mathrm{mg} \cdot \mathrm{gVS}^{-1} \cdot \mathrm{d}^{-1}$ para carga específica de $1,63 \pm 0,48$ mg.gVS ${ }^{-1} \cdot d^{-1}$.

A Etapa III foi caracterizada pela diminuição do TDH para 26,0 $\pm 4,57$ horas. Desse modo, a carga específica de LAS passou de $1,63 \pm 0,48 \mathrm{mg} \cdot \mathrm{gVS}^{-1} \cdot \mathrm{d}^{-1}$ para $2,61 \pm 0,54 \mathrm{mg} \cdot \mathrm{gVS}^{-}$ ${ }^{1} \cdot \mathrm{d}^{-1}$, portanto, variação de aproximadamente $62 \%$. Para maior carga de LAS aplicada por

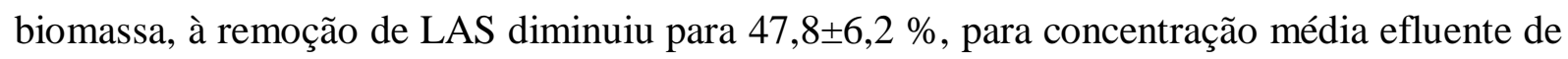
7,51 $\pm 1,0 \mathrm{mg} / \mathrm{L}$. Dessa forma, a mudança no TDH e, conseqüentemente, na carga específica de LAS resultou em variação acentuada da remoção do surfactante.

A Etapa III teve duração de 111 dias, a maior entre todas as etapas impostas ao reator EGSB. Esse prolongado tempo de operação teve por objetivo analisar a possível recuperação da eficiência de remoção do reator para TDH menor. Todavia, os resultados de remoção do surfactante, nessa etapa, não chegaram a atingir $60 \%$.

A Etapa IV foi caracterizada pela retomada das condições impostas na Etapa II. Dessa

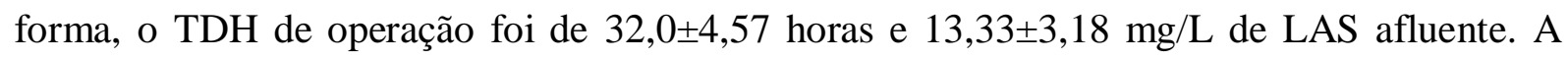
carga específica de LAS nesse período foi de $1,38 \pm 0,54 \mathrm{mg} \cdot \mathrm{gVS}^{-1} \cdot \mathrm{d}^{-1}$, apenas $18 \%$ menor que a carga aplicada na Etapa II $(1,63 \pm 0,48 \mathrm{mg} / \mathrm{L})$ e $89 \%$ menor quando comparado com a Etapa III. Desse modo, com a retomada das condições semelhantes à Etapa II acreditava-se que a remoção de LAS fosse re-estabelecida. Entretanto, a remoção de LAS diminuiu 10\%, quando comparado com a Etapa II, e aumentou 16\% quando comparado com a Etapa III. Testes estatísticos Anova one-way seguido do Teste de Tukey comprovaram diferença significativa na remoção de LAS para as diferentes etapas. 
Provavelmente, a longa exposição da biomassa ao LAS, 211 dias, foi um dos principais fatores que prejudicou a eficiência de sua remoção no sistema. $\mathrm{O}$ efeito dessa exposição prolongada pode ser observado nos resultados obtidos de sólidos (item 5.4), granulometria (item 5.4) e ácidos voláteis totais (item 5.5). A eficiência de remoção de DQO (Tabela 5.1), na etapa Etapa IV foi ligeiramente menor, quando comparado com as demais etapas, porém não estatisticamente diferente. Além disso, foi possível constatar de forma notória que as mudanças de TDH durante a operação do reator EGSB (etapas de operação) afetaram diretamente a remoção do surfactante (Figura 5.4).

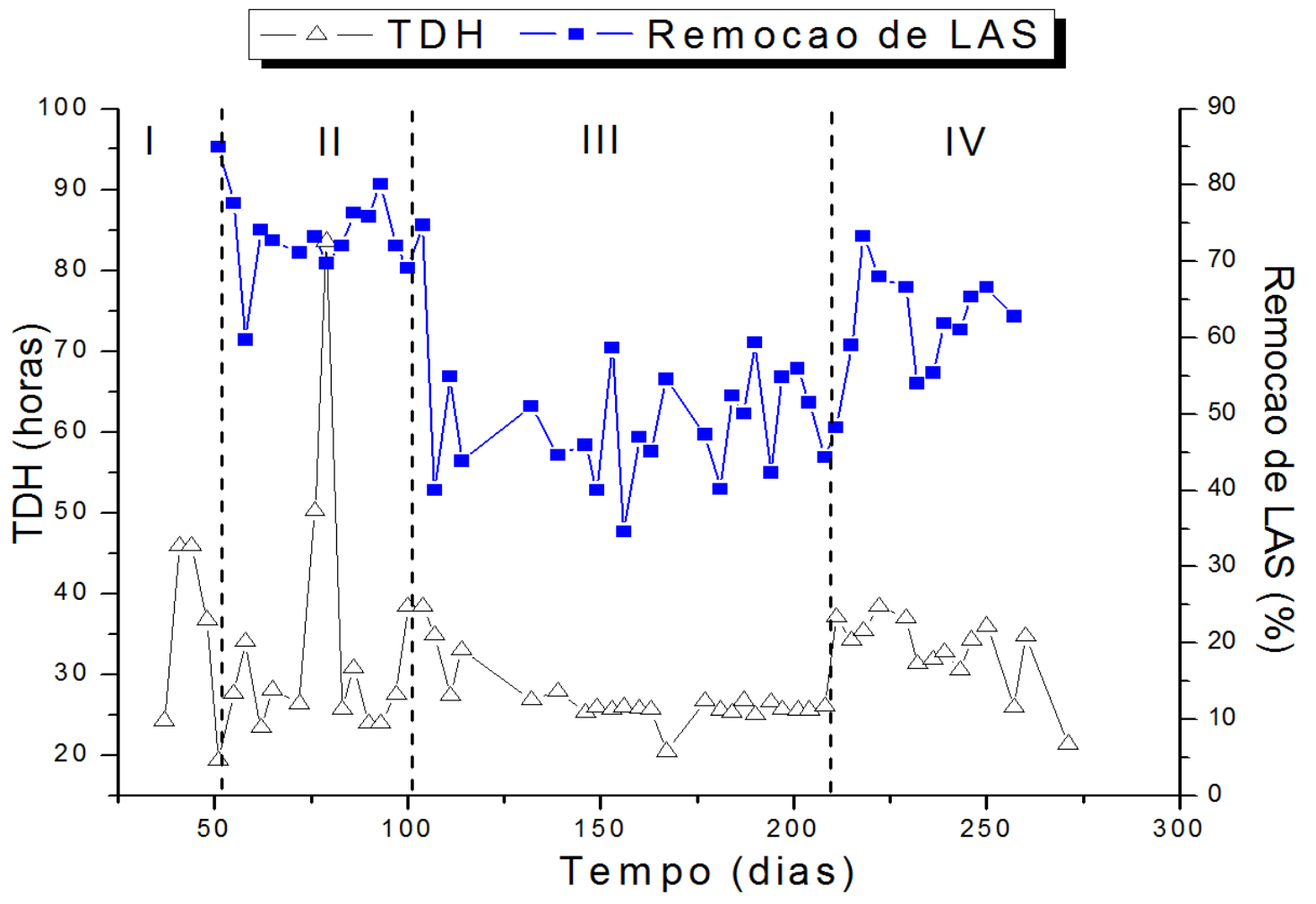

Figura 5.4: Relação TDH e remoção de LAS

Os resultados obtidos nesse estudo, quando comparados com outras pesquisas de remoção de LAS indicaram que o reator EGSB apresentou elevada remoção de LAS nas condições testadas (Tabela 5.3). 
Tabela 5.3: Comparação dos resultados obtidos com a literatura

\begin{tabular}{|c|c|c|c|c|c|c|}
\hline Reator & Inóculo & Alimentação & TDH & $\begin{array}{c}\text { LAS } \\
\text { afluente }\end{array}$ & Remoção & Referência \\
\hline & & & horas & $\mathrm{mg} / \mathrm{L}$ & $\%$ & \\
\hline RAHLF & Lodo de ETE & $\begin{array}{c}\text { LAS + } \\
\text { substrato } \\
\text { sintético }\end{array}$ & 12 & 14 & 35 & $\begin{array}{l}\text { (DUARTE } \\
\text { et al., 2008) }\end{array}$ \\
\hline RAHLF & $\begin{array}{c}\text { UASB abatedouro de } \\
\text { aves }\end{array}$ & $\begin{array}{c}\text { LAS + } \\
\text { substrato } \\
\text { sintético }\end{array}$ & 12 & 14 & 35 & $\begin{array}{l}\text { (DUARTE } \\
\text { et al., 2008) }\end{array}$ \\
\hline RAHLF & $\begin{array}{c}\text { UASB abatedouro de } \\
\text { aves }\end{array}$ & $\begin{array}{c}\text { LAS + } \\
\text { substrato } \\
\text { sintético }\end{array}$ & 12 & 14 & 28 & $\begin{array}{l}\text { (OLIVEIRA } \\
\text { et al., 2009) }\end{array}$ \\
\hline RAHLF & $\begin{array}{c}\text { UASB abatedouro de } \\
\text { aves }\end{array}$ & $\begin{array}{c}\text { LAS + } \\
\text { substrato } \\
\text { sintético }\end{array}$ & 12 & 14 & 27 & $\begin{array}{l}\text { (OLIVEIRA } \\
\text { et al., 2009) }\end{array}$ \\
\hline $\begin{array}{l}\text { Leito } \\
\text { Fluidificado }\end{array}$ & $\begin{array}{c}\text { UASB abatedouro de } \\
\text { aves }\end{array}$ & $\begin{array}{c}\text { LAS + } \\
\text { substrato } \\
\text { sintético }\end{array}$ & 18 & 45 & 93 & $\begin{array}{c}\text { DE } \\
\text { OLIVEIRA } \\
\text { et al., } \\
2010 \mathrm{~b}) \\
\end{array}$ \\
\hline EGSB & $\begin{array}{c}\text { UASB abatedouro de } \\
\text { aves }\end{array}$ & $\begin{array}{l}\text { LAS + Meio } \\
\text { Mineral }\end{array}$ & 32 & 14 & 74 & $\begin{array}{l}\text { Nesse } \\
\text { Estudo }\end{array}$ \\
\hline EGSB & $\begin{array}{l}\text { UASB abatedouro de } \\
\text { aves }\end{array}$ & $\begin{array}{c}\text { LAS + Meio } \\
\text { Mineral }\end{array}$ & 26 & 14 & 48 & $\begin{array}{l}\text { Nesse } \\
\text { Estudo }\end{array}$ \\
\hline
\end{tabular}

As características hidráulicas do reator EGSB, tais como, recirculação do efluente e, conseqüentemente, melhor transferência de massa foram atributos positivos que permitiram alcançar elevada remoção de LAS. Assim como, o efeito do TDH sobre a remoção do surfactante, explicado anteriormente. A diluição da alimentação em cada etapa de operação (Tabela 4.1) em virtude da recirculação do efluente diminuiu a toxicidade do surfactante contribuindo para sua remoção.

\subsection{Alcalinidade, $p H$, Sulfato e Sulfeto}

Por se tratar de um processo anaeróbio, o controle de variáveis como $\mathrm{pH}$ e alcalinidade é essencial para otimização da remoção de matéria orgânica. Mudanças bruscas nesses parâmetros afetam a microbiota presente no reator, comprometendo o processo como um todo. Dessa forma, foi monitorado semanalmente esses parâmetros visando a manutenção da estabilidade do reator com valores de $\mathrm{pH}$ (Tabela 5.4) próximos da neutralidade ( $\mathrm{pH} 7,0$ ), para tanto ocorreu, também, o monitoramente da alcalinidade (Tabela 5.4). A manutenção da estabilidade do reator segundo Lobner et al. (2005) aumenta a eficiência de remoção de LAS. 
As variações de $\mathrm{pH}$ afluente entre as etapas de operação não ultrapassaram 3\% quando comparadas entre si. Mesmo com a adição de LAS, na Etapa II, não ocorreu comprometimento do $\mathrm{pH}$ do sistema. Em relação ao efluente, a variação em porcentagem não ultrapassou $4 \%$ comparando todas as etapas. O menor valor obtido foi para a Etapa I, com

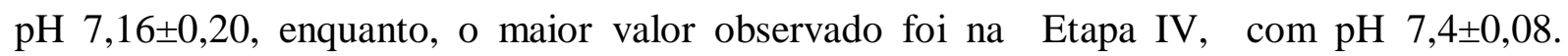
Portanto, de modo geral a adição do LAS não comprometeu o pH do sistema.

Tabela 5.4: Valores médios de $\mathrm{pH}$, alcalinidade, sulfato e sulfeto

\begin{tabular}{|c|c|c|c|c|}
\hline \multirow{2}{*}{ Parâmetros } & \multicolumn{4}{|c|}{ Etapas } \\
\hline & I & II & III & IV \\
\hline \multicolumn{5}{|l|}{$\overline{\mathbf{p H}}$} \\
\hline Afluente & $7,47 \pm 0,26$ & $7,66 \pm 0,06$ & $7,67 \pm 0,14$ & $7,62 \pm 0,07$ \\
\hline Efluente & $7,16 \pm 0,20$ & $7,27 \pm 0,11$ & $7,27 \pm 0,13$ & $7,4 \pm 0,08$ \\
\hline \multicolumn{5}{|c|}{ Alcalinidade Parcial $\left(\mathrm{mg} \mathrm{CaCO}_{3} / \mathrm{L}\right)$} \\
\hline Afluente & $245 \pm 57$ & $315 \pm 23$ & $325 \pm 34$ & $357 \pm 25$ \\
\hline Efluente & $170 \pm 45$ & $283 \pm 16$ & $288 \pm 32$ & $309 \pm 36$ \\
\hline \multicolumn{5}{|c|}{ Alcalinidade Total $\left(\mathrm{mg} \mathrm{CaCO}_{3} / \mathrm{L}\right)$} \\
\hline Afluente & $314 \pm 67$ & $399 \pm 18$ & $435 \pm 45$ & $457 \pm 29$ \\
\hline Efluente & $230 \pm 51$ & $371 \pm 23$ & $395 \pm 36$ & $395 \pm 47$ \\
\hline \multicolumn{5}{|l|}{ Sulfato $(\mathrm{mg} / \mathrm{L})$} \\
\hline Afluente & - & - & - & - \\
\hline Efluente & - & $2,29 \pm 1,26$ & $3,21 \pm 3,9$ & $3,13 \pm 5,1$ \\
\hline \multicolumn{5}{|l|}{ Sulfeto $(\mathrm{mg} / \mathrm{L})$} \\
\hline Afluente & - & - & - & - \\
\hline Efluente & - & $0,275 \pm 1,3$ & $0,111 \pm 3,9$ & $0,04 \pm 5,1$ \\
\hline TDH $(\mathrm{h})$ & $32,2 \pm 10,2$ & $32,0 \pm 15,1$ & $26,0 \pm 4,5$ & $32,0 \pm 4,5$ \\
\hline LAS Afluente (mg/L) & - & $14,04 \pm 1,2$ & $14,41 \pm 1,0$ & $13,33 \pm 3,2$ \\
\hline Duração (dias) & 48 & 52 & 111 & 74 \\
\hline
\end{tabular}

Bicarbonato de sódio foi adicionado ao reator de forma gradativa, portanto, justifica o baixo valor de alcalinidade afluente na Etapa I, tanto, para alcalinidade parcial, como para alcalinidade total, quando comparado com as demais etapas. A variação afluente da alcalinidade parcial foi de $45 \%$ comparando-se a Etapa I (menor valor, $245 \mathrm{mg} \mathrm{CaCO} / \mathrm{L}$ ) com a Etapa IV (maior valor, $357 \mathrm{mgCaCO}_{3} / \mathrm{L}$ ). A adição de LAS não afetou a alcalinidade parcial afluente e efluente do reator (Tabela 5.4).

Ocorreu variação de 7,5\%,10\% e 15\% da alcalinidade total afluente e efluente nas Etapas II, III e IV, respectivamente. Analisando os resultados de $\mathrm{pH}$, alcalinidade total e 
parcial pode-se inferir que o sistema apresentou boa capacidade de tamponamento, e conseqüentemente, operação estável.

Em relação aos compostos de enxofre, deve-se salientar que na composição nutricional do meio mineral (Tabela 4.3) não está contemplada fonte de enxofre. Portanto, a única fonte de enxofre na alimentação do reator foi o LAS (Figura 3.1). Portanto, os baixos valores obtidos com relação a sulfato e sulfeto (Figura 5.5 Figura 5.6) foram em virtude da baixa concentração de enxofre na molécula de LAS. As análises de sulfato e sulfeto ocorreram apenas após a adição do LAS tentando estabelecer relação entre remoção de LAS e produção de sulfato/sulfeto.

A etapa final da degradação do LAS é a abertura do anel aromático. Quando isso acontece, a degradação progride rapidamente com a formação de biomassa, dióxido de carbono, água e sulfato. A etapa mais difícil é a ruptura da ligação do radical alquila com o anel aromático sulfonado (CAVALLI et al. 1993).

Em sistemas de lodos ativados Cordon et al. (1968) observaram liberação de sulfato proveniente do grupo sulfonado do LAS, após 21 dias de operação, correspondendo a $89 \%$ da quantidade teórica de LAS adicionada ao reator. Os estágios finais da degradação do LAS correspondem a ruptura do anel aromático e, conseqüentemente, liberação de sulfato.

Denger et al. (1997) observaram que o LAS pode ser usado como fonte de enxofre para bactérias anaeróbias sob condições limitadas de sulfato. Os autores usaram cultura enriquecida com LAS em condição anóxica, em meio contendo glicose. Segundo os autores ocorreu a utilização do surfactante, como fonte de enxofre, para o crescimento microbiano. Nessa cultura foi constatada similaridade com bactérias dos gêneros Aeromonas (88,2 $90,1 \%)$ e Shewanella $(87-88,1 \%)$.

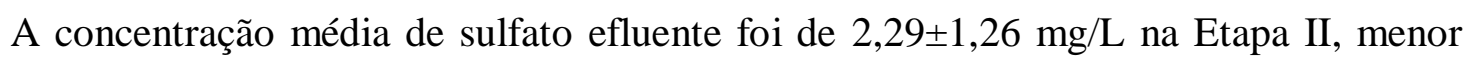
valor entre todas as etapas. Na Etapa III ocorreu aumento de $40 \%$, ou seja, esse valor foi de

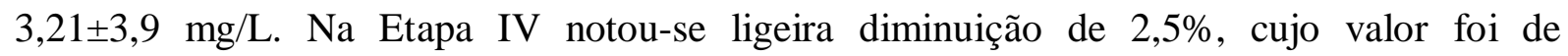
$3,13 \pm 5,1 \mathrm{mg} / \mathrm{L}$. Destaca-se, portanto, que para concentração reduzida de enxofre, é favorecida a redução assimilativa de sulfato , uma vez que o enxofre é incorporando em constituintes celulares, principalmente aminoácidos e, portanto, baixa produção de sulfeto. Todavia, o sulfeto pode ter sido produzido e, imediatamente consumido por outros microrganismos.

As oscilações nos valores de sulfato podem ser originárias das seguintes considerações: (1) proveniente da oxidação direta do sulfito da molécula de LAS, (2) 
proveniente do desproporcionamento biológico do sulfito com formação de sulfato e ácido sulfídrico, (3) e utilização do sulfato para redução assimilativa.

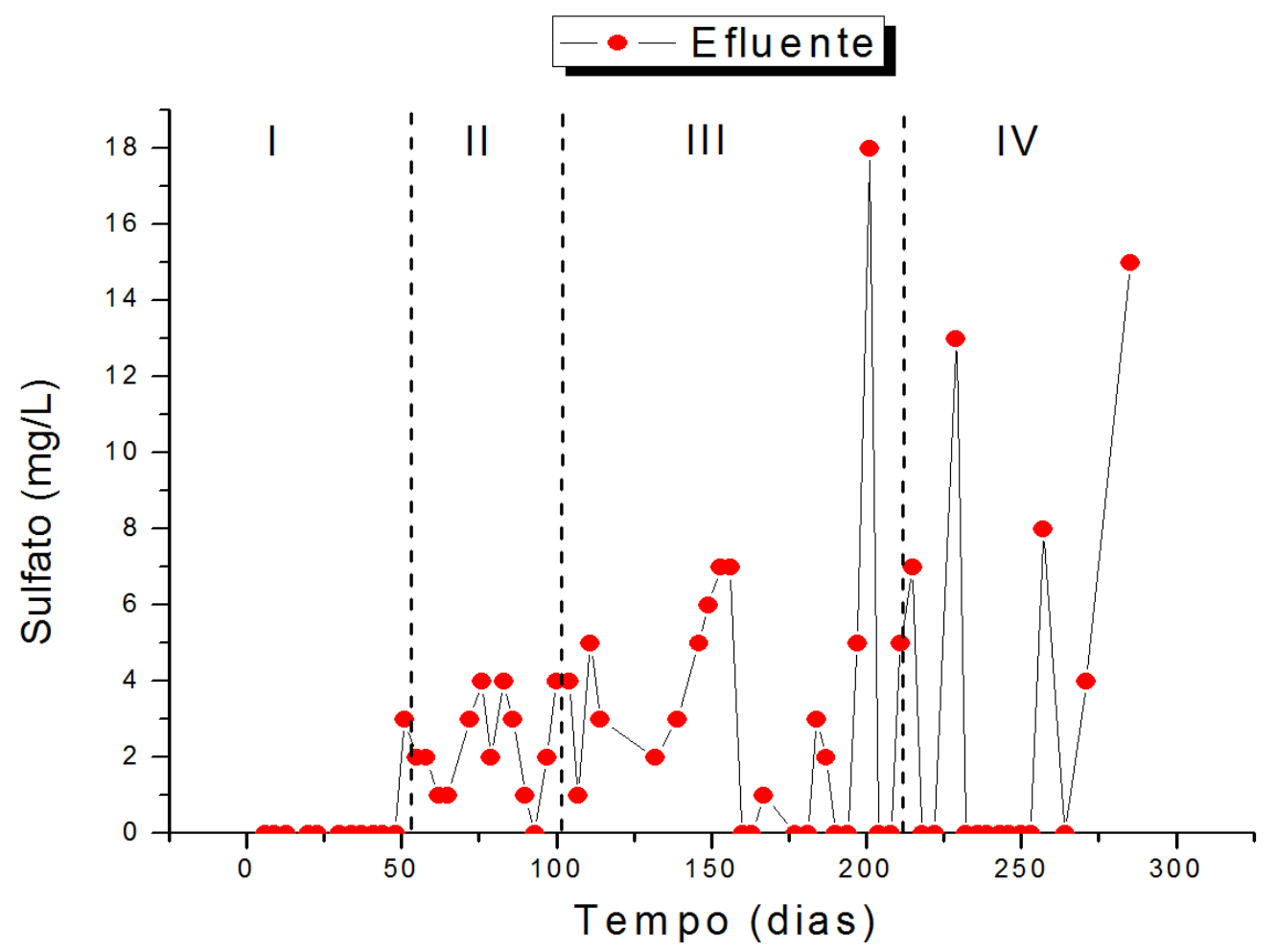

Figura 5.5: Variação temporal do sulfato

Os valores médios de sulfeto efluente não ultrapassaram a 0,3 mg/L. Notou-se diminuição da concentração de sulfeto durante a operação do reator EGSB. O maior valor obtido foi na Etapa II com concentração afluente de 0,275 $\pm 1,3 \mathrm{mg} / \mathrm{L}$, seguido de 0,111 $\pm 3,9 \mathrm{mg} / \mathrm{L}$ na Etapa III e $0,04 \pm 5,1 \mathrm{mg} / \mathrm{L}$ na Etapa IV. Valores próximos foram obtidos por Oliveira, 2010, com concentrações baixas de sulfato e sulfeto, todavia, utilizando extrato de levedura na alimentação que representava uma fonte extra de enxofre excluindo o LAS. 


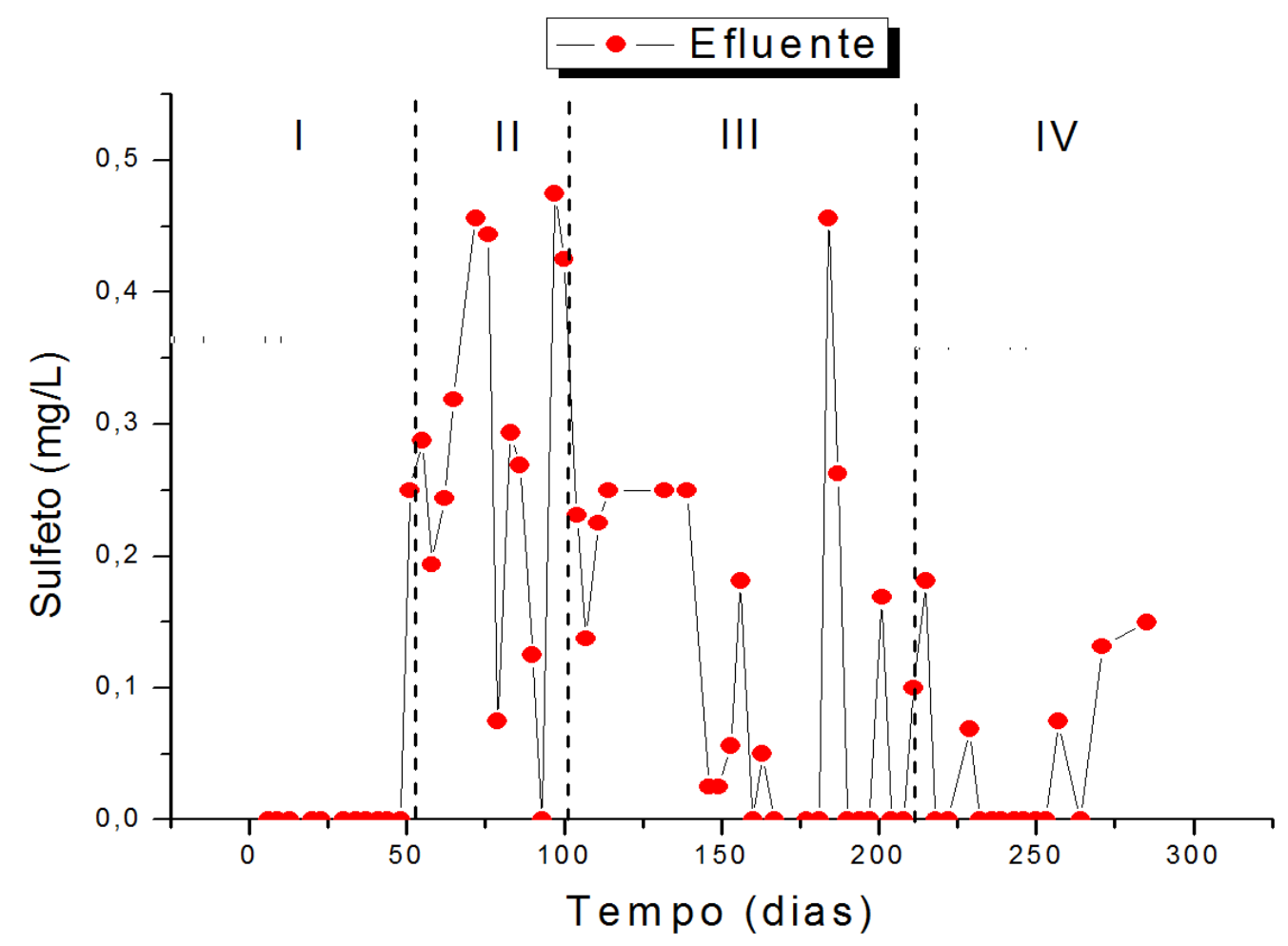

Figura 5.6: Variação temporal do sulfeto

\subsection{Granulometria e Sólidos Totais}

Os valores de sólidos totais e sólidos voláteis efluente durante a operação do reator EGSB estão apresentados na Tabela 5.5. Os valores de granulometria referentes as etapas I, III e IV estão descritos na Tabela 5.6 e mostrados na Figura 5.7. A granulometria das amostras da Etapa II não foi realizada, uma vez que os valores de sólidos totais estavam elevados. Dessa forma a retirada de mais biomassa para essa análise poderia desestabilizar o reator.

Tabela 5.5: Resultados de sólidos do reator EGSB

\begin{tabular}{lcccc}
\hline \multicolumn{1}{c}{ Parâmetros } & I & II & III & IV \\
\hline Sólidos & 0,049 & 0,128 & 0,064 & 0,038 \\
\hline Totais (g/L) & 0,049 & 0,128 & 0,045 & 0,038 \\
Voláteis (g/L) & $32,2 \pm 10,2$ & $32,0 \pm 15,16$ & $26,0 \pm 4,57$ & $32,0 \pm 4,57$ \\
\hline TDH (h) & - & $14,04 \pm 1,2$ & $14,41 \pm 1,0$ & $13,33 \pm 3,2$ \\
LAS Afluente (mg/L) & 48 & 52 & 111 & 74 \\
Duração (dias) & & & & \\
\hline
\end{tabular}


A Etapa I foi caracterizada por apresentar 0,049 g/L de sólidos totais. A adição de LAS na Etapa II acarretou em aumento de sólidos totais de $261 \%$, ou seja, teve aumento acentuado na quantidade de sólidos no efluente. A hipótese mais plausível para este fenômeno, provavelmente, foi a instabilidade devido à adição de LAS no reator de forma abrupta, ou seja, em concentração de 14,04+1,2mg/L.

A não adaptação da biomassa afeta negativamente os microrganismos, desestruturando o grânulo. Ruffo et al. (1999) estudou a degradação do LAS por processos aeróbios utilizando inóculo adaptado e não adaptado. Os autores constataram que a adaptação do inóculo com LAS representou um ganho na taxa de remoção de surfactante, assim como, tendência no aumento da sua remoção. Para o lodo adaptado a biodegradação em 28 dias foi de 69,6\%, enquanto que para o lodo não adaptado foi de $66,7 \%$.

Dessa forma, no reator EGSB, os grânulos tiveram efeito negativo (diminuição do diâmetro médio) com a adição do LAS, uma vez que este não foi adicionado de forma gradativa na alimentação do reator. Além do aumento da quantidade de sólidos efluente, outros efeitos foram observados, tais como, aumento da concentração de ácidos totais voláteis (Tabela 5.7).

Embora, o grânulo funcione com estrutura protetora, principalmente para as arquéias metanogênicas que são mais sensíveis a compostos tóxicos como o LAS, tal estrutura foi relativamente suficiente para a proteção dos microrganismos.

$\mathrm{Na}$ Etapa III a concentração de sólidos totais foi de $0,064 \mathrm{~g} / \mathrm{L}$, exatamente $50 \%$ menor que a fase anterior. Decorrido, 52 dias de operação com LAS na concentração de 14,04 $\pm 1,2 \mathrm{mg} / \mathrm{L}$ e TDH de 32 horas, a biomassa estava mais adaptada a condição com LAS, portanto a concentração de sólidos totais efluente foi bem menor. Deve-se destacar que a maior parte dos sólidos efluente correspondeu aos sólidos totais voláteis que representam em grande parte a biomassa. Essa evidencia, também foi observada na Etapa IV que apresentou $0,038 \mathrm{~g} / \mathrm{L}$ de sólidos totais. 
Tabela 5.6: Distribuição do diâmetro dos grânulos nas diferentes etapas

\begin{tabular}{cccc}
\hline & \multicolumn{2}{c}{ Etapas } \\
Intervalo de Classes & $\mathbf{I}$ & III & IV \\
\hline $\mathbf{c m})$ & \multicolumn{3}{c}{$\begin{array}{c}\text { Freqüências } \\
\mathbf{( \% )}\end{array}$} \\
\hline $0,00-0,05$ & 0 & 0 & 0 \\
$0,05-0,10$ & 0 & 0 & 0 \\
$0,10-0,15$ & 0 & 0 & 0 \\
$0,15-0,20$ & 0 & 1 & 0 \\
$0,20-0,25$ & 1 & 0 & 0 \\
$0,25-0,30$ & 6 & 2 & 23 \\
$0,30-0,35$ & 36 & 28 & 54 \\
$0,35-0,40$ & 40 & 42 & 18 \\
$0,40-0,45$ & 13 & 10 & 4 \\
$0,45-0,50$ & 2 & 1 & 0 \\
$0,50-0,55$ & 1 & 0 & 0 \\
$0,55-0,60$ & 0 & 0 & 0 \\
$0,60-0,65$ & 0 & 0 & 0 \\
\hline Diâmetro médio dos grânulos & & & \\
$(\mathbf{c m})$ & $0,36 \pm 0,044$ & $0,36 \pm 0,038$ & $0,34 \pm 0,036$ \\
\hline
\end{tabular}

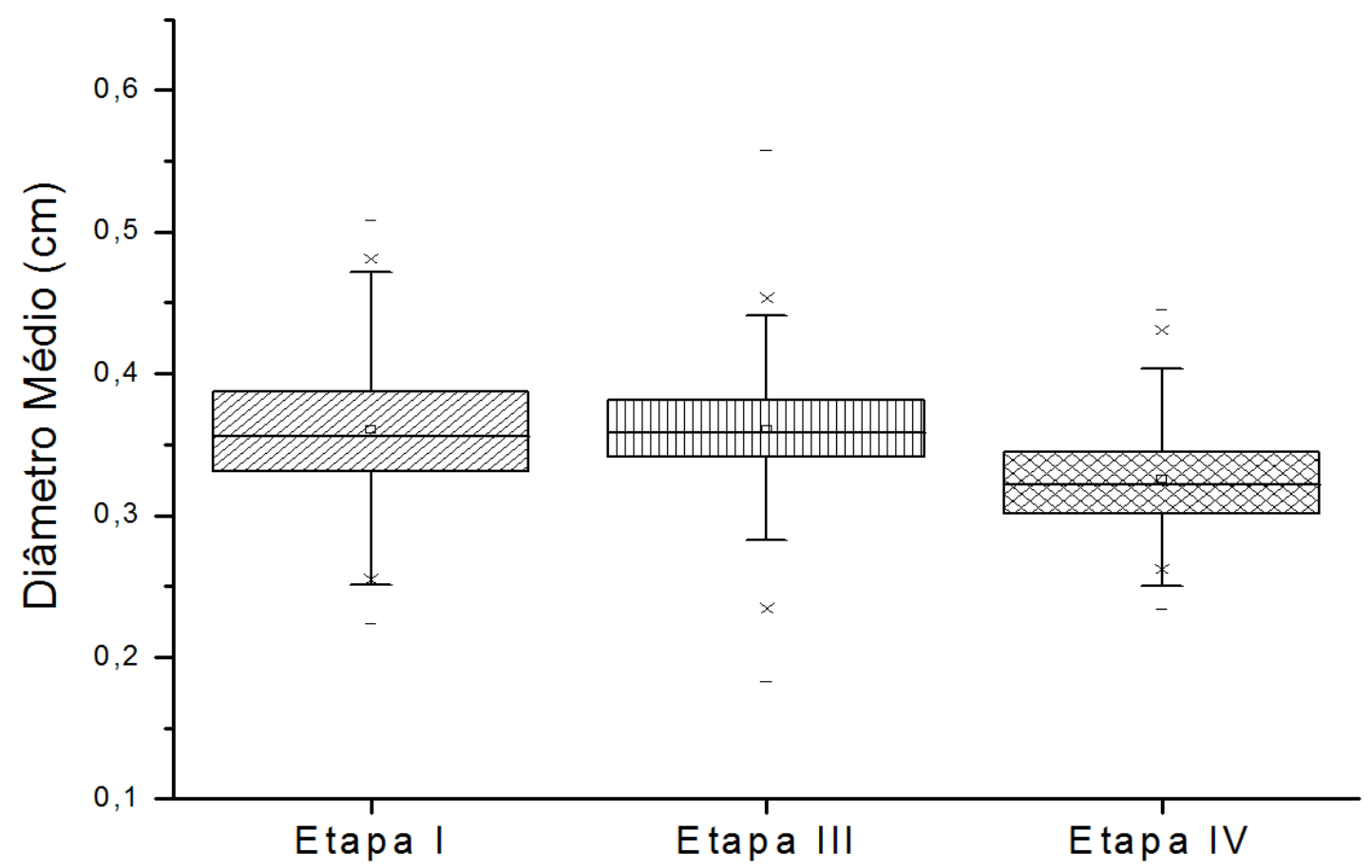

Figura 5.7: Granulometria das Etapas I, II e IV. As barras representam os valores máximos e mínimos e o $(\square)$ mostra a média. 
Na Etapa I, foi verificada maior freqüência de grânulos com diâmetro de 0,35 - 0,40 (cm) e média de 0,36 $\pm 0,044 \mathrm{~cm}$ (Tabela 5.6). Na Etapa III os resultados foram semelhantes a

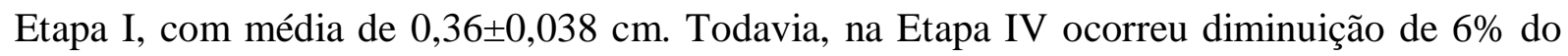
diâmetro médio dos grânulos, com média de $0,34 \pm 0,036 \mathrm{~cm}$. Duas explicações são possíveis para isso, longo tempo de exposição da biomassa ao surfactante (163 dias) e/ou resultado do longo período da Etapa III, com carga de LAS mais elevada que as outras etapas (111 dias e $\left.2,61 \pm 0,54 \mathrm{mgLAS} \cdot \mathrm{gVS}^{-1} \cdot \mathrm{d}^{-1}\right)$.

\section{5 Ácidos Voláteis Totais}

Na Tabela 5.7 estão descritos os resultados de ácidos voláteis totais de duas formas: concentração de ácidos voláteis totais em cada etapa e concentração total média de cada ácido específico.

Tabela 5.7: Média de ácidos voláteis totais efluente nas etapas de operação do reator

\begin{tabular}{|c|c|c|c|c|}
\hline \multirow[b]{3}{*}{ Concentração } & \multicolumn{4}{|c|}{ Etapas } \\
\hline & I & II & III & IV \\
\hline & \multicolumn{4}{|c|}{$(\mathrm{mg} / \mathrm{L})$} \\
\hline Cítrico & $<\mathrm{LD}^{*}$ & $<\mathrm{LD}^{*}$ & $<\mathrm{LD}^{*}$ & $<\mathrm{LD} *$ \\
\hline Málico & $<\mathrm{LD}^{*}$ & $<\mathrm{LD}^{*}$ & $<\mathrm{LD}^{*}$ & $<\mathrm{LD}^{*}$ \\
\hline Succínico & $<\mathrm{LD} *$ & $<\mathrm{LD} *$ & 0,53 & 0,58 \\
\hline Lático & $<\mathrm{LD}^{*}$ & $<\mathrm{LD}^{*}$ & 4,62 & 4,98 \\
\hline Fórmico & $<\mathrm{LD}^{*}$ & $<\mathrm{LD}^{*}$ & $<\mathrm{LD}^{*}$ & 0,81 \\
\hline Acético & 3,45 & 8,59 & 6,03 & 5,00 \\
\hline Propiônico & $<\mathrm{LD}^{*}$ & $<\mathrm{LD}^{*}$ & 3,52 & 5,79 \\
\hline Isobutírico & $<\mathrm{LD}^{*}$ & $<\mathrm{LD}^{*}$ & 9,62 & 11,76 \\
\hline Butírico & $<\mathrm{LD}^{*}$ & 0,53 & 4,73 & 9,30 \\
\hline Isovalérico & $<\mathrm{LD}^{*}$ & $<\mathrm{LD}^{*}$ & 2,54 & 0,91 \\
\hline Valérico & $<\mathrm{LD}^{*}$ & $<\mathrm{LD}^{*}$ & 2,86 & 3,86 \\
\hline Capróico & $<\mathrm{LD}^{*}$ & $<\mathrm{LD} *$ & 3,13 & 3,37 \\
\hline Somatória & 3,45 & 9,12 & 37,59 & 46,38 \\
\hline TDH (h) & $32,2 \pm 10,2$ & $32,0 \pm 15,16$ & $26,0 \pm 4,57$ & $32,0 \pm 4,57$ \\
\hline LAS Afluente (mg/L) & - & $14,04 \pm 1,2$ & $14,41 \pm 1,0$ & $13,33 \pm 3,2$ \\
\hline Duração (dias) & 48 & 52 & 111 & 74 \\
\hline
\end{tabular}

*limite de detecção

$\mathrm{Na}$ Etapa I foi detectado apenas ácido acético $(3,5 \mathrm{mg} / \mathrm{L})$. Os valores desse ácido nas demais etapas foram de 8,59 mg/L (Etapa II), 6,03 mg/L (Etapa III) e 5,00 mg/L( Etapa IV). 
Portanto, o maior valor efluente foi observado na Etapa II, na qual foi adicionado LAS $(14,04 \pm 1,26 \mathrm{mg} / \mathrm{L})$ e TDH de 32 horas. O reduzido acúmulo de ácido acético pode estar relacionado com a diminuição das arquéias metanogênicas acetoclásticas, possivelmente devido à adição de LAS no reator. Todavia, nas etapas seguintes foi observada diminuição da concentração média do ácido acético efluente indicando adaptação da biomassa a condição com LAS (Figura 5.15). Ácido isobutírico não foi detectado nas Etapas I e II, entretanto, foi predominante nas Etapas III (9,62 mg/L) e IV (11,76mg/L).

A concentração de ácidos voláteis totais aumentou durante a operação do reator EGSB (Tabela 5.7). Esse aumento foi verificado entre as Etapas II e III (9,12 mg/L para 37,59 $\mathrm{mg} / \mathrm{L})$, provavelmente, devido ao aumento da carga específica de LAS aplicada na Etapa III. Entre as Etapas III e IV ocorreu aumento de $23 \%$ na concentração ácidos voláteis totais. As condições hidráulicas de operação do reator foram semelhantes nas Etapas II e IV, todavia, a biomassa da Etapa IV encontrava-se exposta por longo período ao LAS. Essa longa exposição afetou o crescimento dos microrganismos e, conseqüentemente, o processo como um todo.

Nesse estudo, não foi observada relação entre a concentração de ácido acético e remoção de LAS. Lobner et al. (2005) utilizaram reator UASB alimentado com meio mineral contendo glicose $(1 \mathrm{~g} / \mathrm{L})$ e LAS $(10 \mathrm{mg} / \mathrm{L})$. Os autores obtiveram remoção de 40 a $80 \%$ de LAS. As maiores taxas de remoção de LAS foram obtidas para concentração de ácido acético abaixo de 50mg/L.

Por outro lado, foi possível verificar relação entre a somatória de ácidos voláteis efluente e eficiência de remoção de LAS. As maiores remoções foram obtidas para as menores concentrações de ácidos voláteis totais, fato este também observado por Lobner et al. (2005). Ahring et al. (1995) observaram que o aumento da concentração de ácidos voláteis foi indicador de instabilidade do processo anaeróbio. Portanto, a estabilidade do reator é essencial para obtenção de maiores remoções do surfactante. 


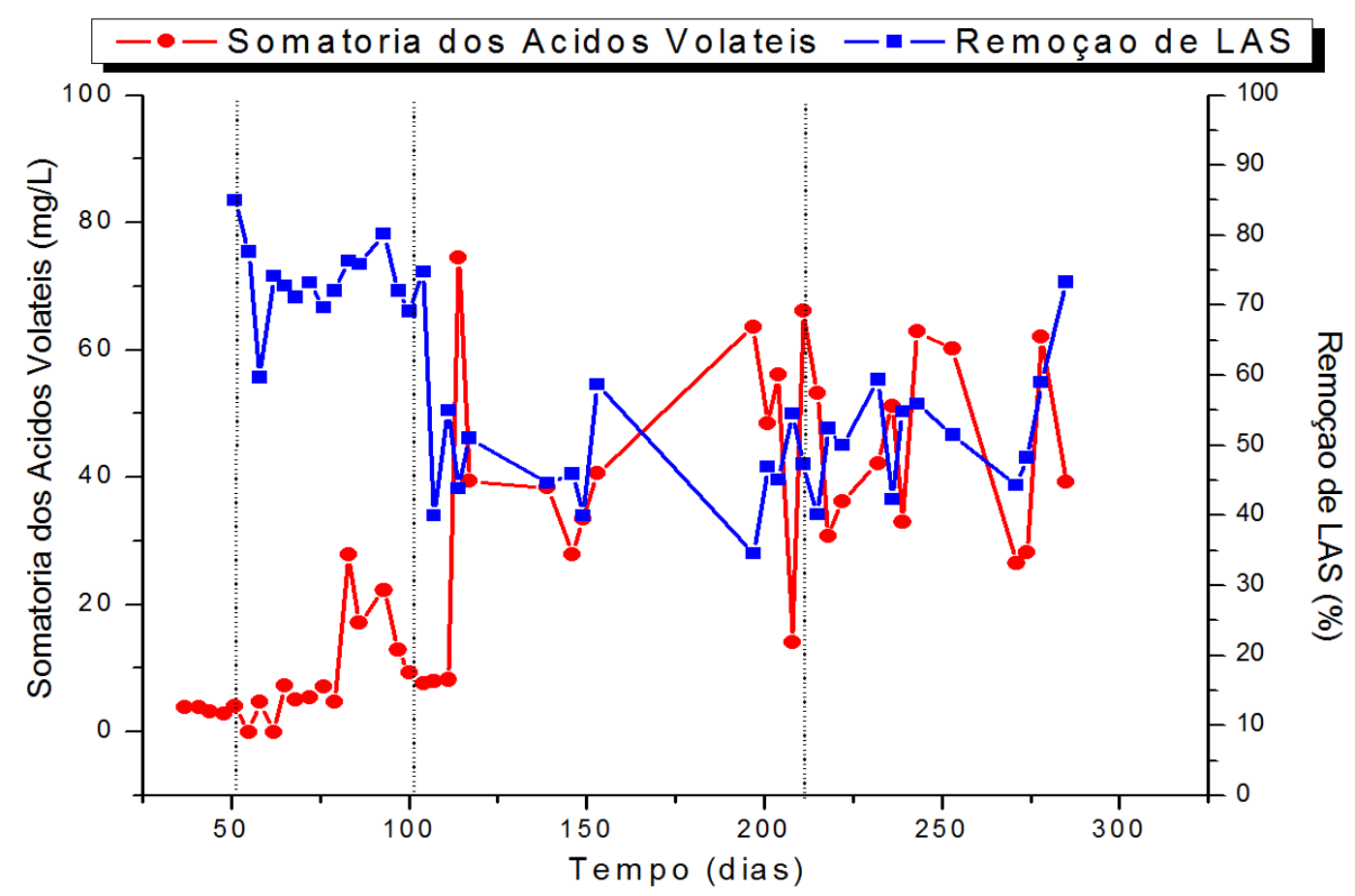

Figura 5.8: Variação temporal da remoção de LAS e s ácidos voláteis efluente

\subsection{Anaerobiose do reator EGSB}

O ensaio de anaerobiose do reator foi realizado no $190^{\circ}$ dia de operação. Nesse teste o reator não apresentou coloração rosada ou roxa (Figura 5.9).

A região superior onde acreditava-se que poderia ocorrer micro-aeração apresentou ausência de cor, assim como, todo o leito. A extremidade da mangueira em contato com o frasco de alimentação ficou parcialmente rosada, todavia, antes do afluente entrar no reator essa coloração sumiu. Por aproximadamente, três dias a resazurina permaneceu no sistema. Tal fato foi comprovado, uma vez que, quando eram retiradas amostras para as análises rotineiras do efluente ocorria a mudança da coloração de incolor para rosada, assim que entrava em contato com o ar atmosférico. Isso demonstrou que o reator estava em condição anaeróbia durante a operação.

Além disso, os resultados microbiológicos detalhados na Tabela 5.11, Figura 5.13 e Figura 5.14, juntamente com os valores obtidos semanalmente das análises de potencial redox corroboram com as conclusões obtidas do ensaio com a resazurina. Arquéias metanogênicas estritamente anaeróbias, tais como, bacilos fluorescentes hidrogenotróficos e Methanosarcina são sensíveis a presença de oxigênio (Zhilina, 1972). Tais arquéias foram observadas microscopicamente em todas as etapas de operação. Segundo Zhilina (1972), 
Methanosarcina pertence a um grupo de metanogênicas extremamente sensíveis a presença de oxigênio, a meia-vida de algumas espécies é de 4 minutos em meio com ar-equilibrado. Em parte, a sensibilidade dessas metanogênicas é devido ausência de enzimas (catalase, peroxidase e superóxido dismutase) responsáveis pela catálise das formas tóxicas de oxigênio. 

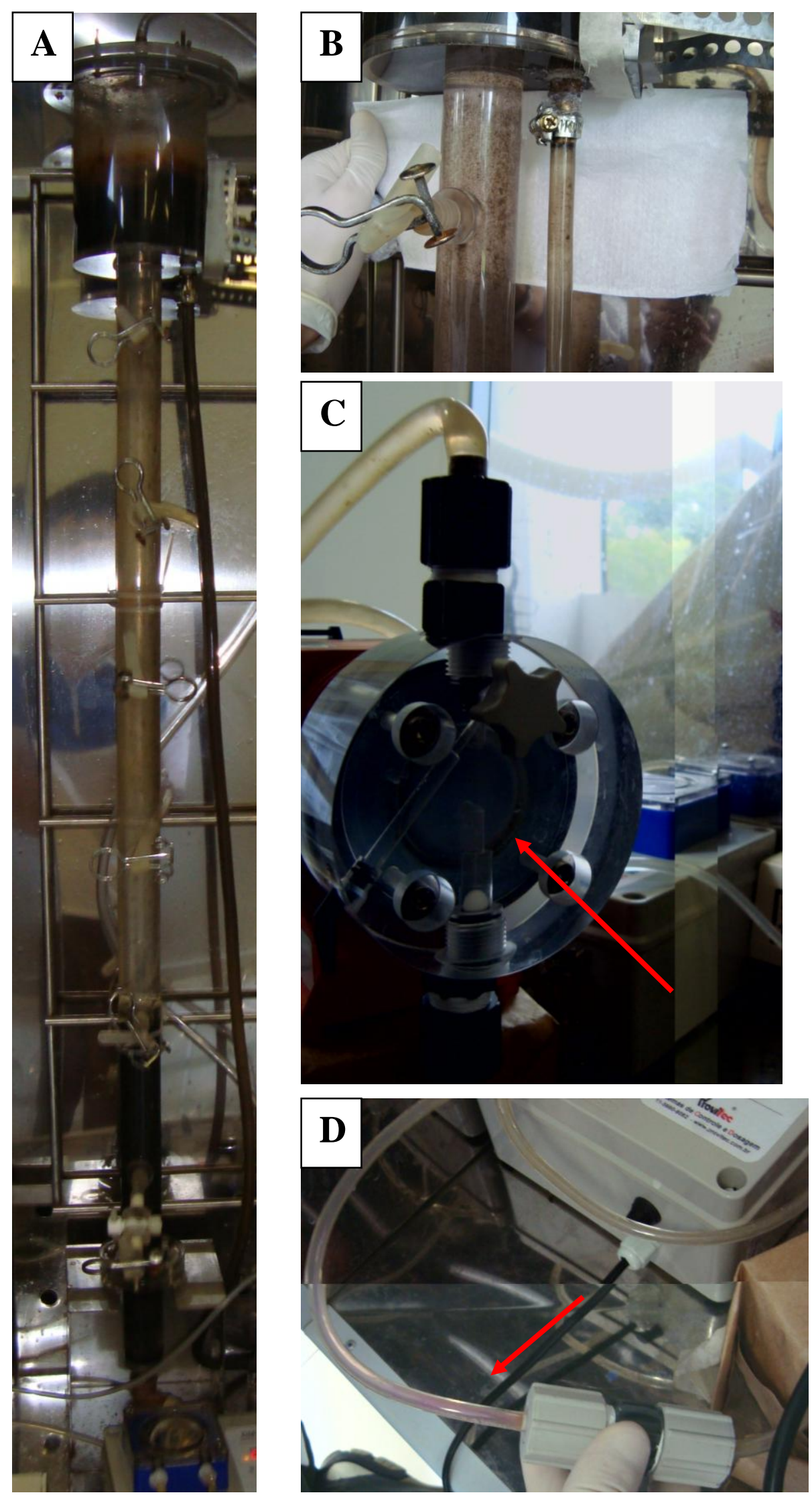

Figura 5.9: Ensaio de anaerobiose do reator. (A) imagem do reator inteiro, (B) região superior do reator, $(\mathbf{C})$ bomba de recirculação (cabeçote) e (D)

Bomba de alimentação (mangueira afluente). 


\subsection{Balanço de Massa de LAS}

O balanço de massa foi realizado apenas no final da operação do reator EGSB. Para tanto, foram adotadas duas estratégias: (1) extração de LAS adsorvido nos grânulos do leito do reator e (2) extração de LAS adsorvido nos SST efluente. Dessa forma, foi possível calcular a massa de LAS removido e a massa de LAS degradado no sistema com base nas fórmulas abaixo.

$$
\begin{gathered}
\text { LAS removido }=\mathrm{LAS}_{\mathrm{afl}}-\mathrm{LAS}_{\mathrm{efl}} \\
\text { LAS degradado }=\mathrm{LAS}_{\mathrm{afl}}-\left(\mathrm{LAS}_{\mathrm{efl}}+\mathrm{LAS}_{\mathrm{ads}}\right)
\end{gathered}
$$

\section{Sendo:}

LAS removido = massa de LAS removida por processos biológicos e físicos

LAS degradado = massa de LAS removida apenas por processos biológicos

$\mathbf{L A S}_{\text {afl }}=$ massa de LAS afluente

$\mathbf{L A S}_{\text {efl }}=$ massa de LAS efluente

$\mathbf{L A S}_{\text {ads }}=$ massa de LAS adsorvido (SST efluente e biomassa do leito)

Na Tabela 5.8 estão apresentados os resultados obtidos em cada situação.

\begin{tabular}{|c|c|c|c|c|c|}
\hline $\begin{array}{l}\text { Amostras para } \\
\text { Extração }\end{array}$ & Etapa & $\begin{array}{c}\text { Biomassa } \\
\text { (g) }\end{array}$ & $\begin{array}{c}\text { Concentração } \\
\text { de LAS } \\
(\mathrm{mg} / \mathrm{L}) \\
\end{array}$ & $\begin{array}{l}\text { Adsorção } \\
\text { (mg/gST) }\end{array}$ & $\begin{array}{c}\text { Média } \\
(\mathbf{m g} / g S T)\end{array}$ \\
\hline Leito & \multirow{2}{*}{ IV } & $\begin{array}{l}0,1498 \\
0,1510\end{array}$ & $\begin{array}{l}15,4 \\
12,8\end{array}$ & $\begin{array}{l}16,4 \\
13,6\end{array}$ & $15,00 \pm 2,04$ \\
\hline SST Efluente & & $\begin{array}{l}0,1570 \\
0,2210\end{array}$ & $\begin{array}{l}15,2 \\
16,6\end{array}$ & $\begin{array}{l}15,5 \\
12,0\end{array}$ & $13,75 \pm 2,45$ \\
\hline
\end{tabular}

Tabela 5.8: Valores da extração de LAS no leito e SST efluente

O valor da extração de LAS obtido na biomassa do leito do reator foi de 15,00 $\pm 2,04$ $\mathrm{mg} / \mathrm{gST}$ e o valor obtido no SST efluente foi de $13,75 \pm 2,45 \mathrm{mg} / \mathrm{gST}$. A variação entre as extrações foi de $9 \%$, a pequena diferença entre os dois valores devem-se as características intrínsecas da biomassa nas duas situações, além das características da própria molécula de LAS. 
Na Figura 5.10 encontra-se apresentado cromatograma típico de uma extração de LAS adsorvido comparado com cromatograma de LAS em meio líquido (afluente). A adsorção da molécula de LAS está relacionada com a hidrofobicidade dos seus homólogos, uma vez que o caráter hidrofóbico é proporcional ao tamanho da cadeia alquílica. Portanto, quanto maior a cadeia alquílica, maior a hidrofobicidade da molécula e maior a adsorção.

Esse comportamento é facilmente visualizado quando compara-se os quatro homólogos da molécula de LAS de uma amostra de extração de LAS adsorvido (Figura 5.10a); o homólogo com 13 átomos de carbono na cadeia alquílica adsorveu mais e, portanto, ficou mais concentrado nesse tipo de amostra.

A distribuição entre os homólogos pode ser visualizada na Figura 5.10b. Segundo, Duarte (2006), a porcentagem dos homólogos na molécula de LAS comercial Aldrich (CAS 25155-30-0) é a seguinte: $18 \%$ para C 10,36\% para C 11, 28\% para C 12 e $18 \%$ para C 13 para LAS.
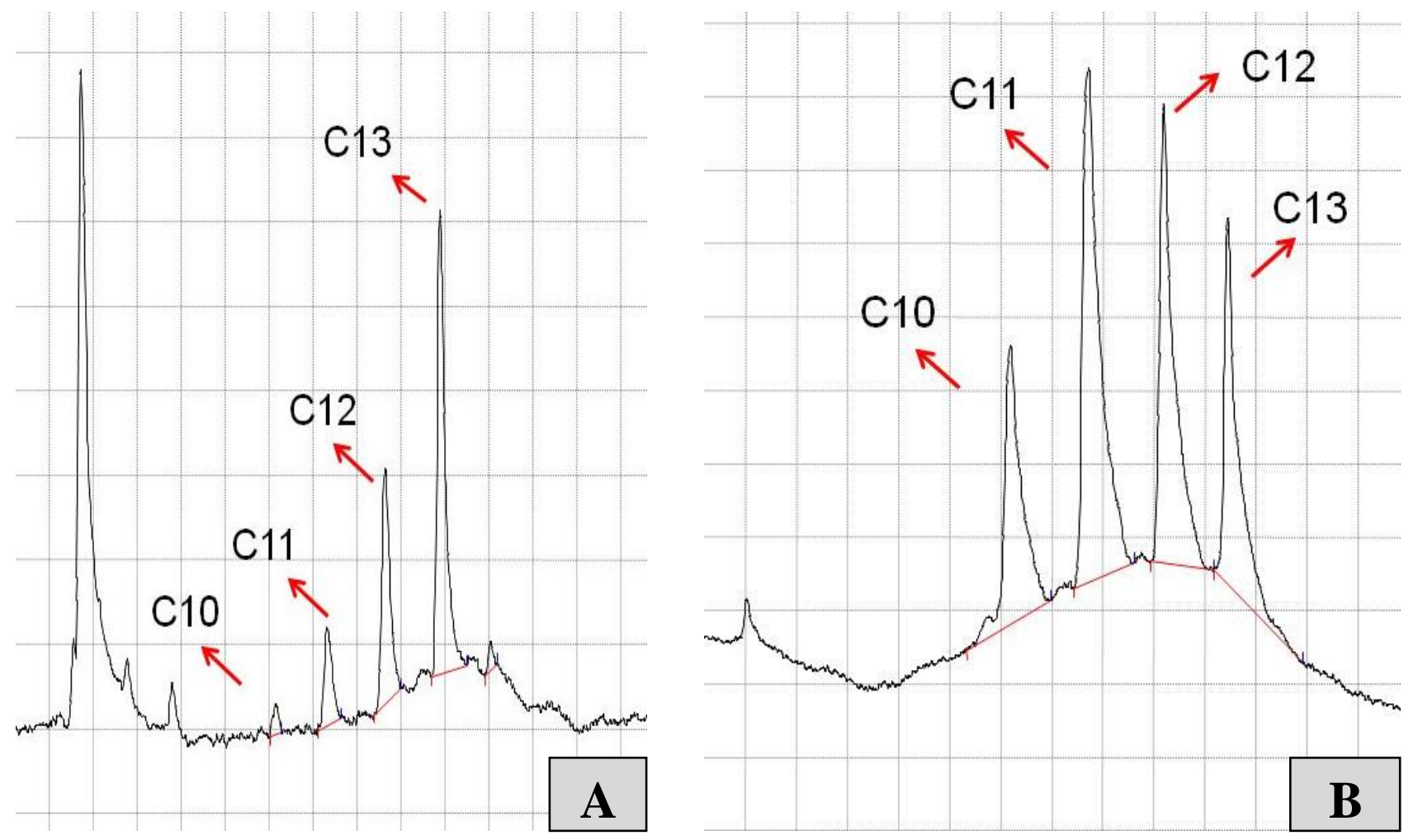

Figura 5.10: (A) Cromatograma típico de uma extração de LAS. (B)

Cromatograma de LAS afluente 


\subsubsection{Balanço de Massa Afluente e Efluente}

O balanço de massa afluente e efluente refere-se à massa de LAS que entrou no reator EGSB e a massa de LAS que foi recuperada no efluente. Para tanto, foram consideradas as seguintes variáveis, tanto, para o afluente, como para o efluente: vazão diária, tempo e concentração de LAS (afluente/efluente).

$$
\operatorname{Massa~LAS~}_{(\mathrm{Afl} / \mathrm{Efl})}=[\mathrm{LAS}] \times \mathrm{Q} \times \mathrm{T}
$$

Sendo:

Massa LAS $_{(\mathbf{A f l} / \mathbf{E f l})}=$ massa de LAS acumulada afluente/efluente

[LAS $]=$ concentração de LAS afluente/efluente $(\mathrm{mg} / \mathrm{L})$

$\mathbf{Q}=$ vazão afluente/efluente $(1 / \mathrm{h})$

$\mathbf{T}=$ tempo de operação do reator $(\mathrm{h})$

Portanto, a porcentagem total de LAS removido foi de $57 \%$ considerando todas as etapas de adição do surfactante (Tabela 5.9).

Tabela 5.9: Balanço de massa LAS afluente/efluente e porcentagem de remoção

\begin{tabular}{ccc}
\hline $\begin{array}{c}\text { Afluente } \\
\text { mg LAS }\end{array}$ & $\begin{array}{c}\text { Efluente } \\
\text { mgLAS }\end{array}$ & $\begin{array}{c}\text { Remoção } \\
\%\end{array}$ \\
\hline 3917,64 & 1698,73 & 57 \\
\hline
\end{tabular}

\subsubsection{Balanço de Massa nos Grânulos do leito do reator}

Parte da massa de LAS que entrou no sistema ficou adsorvida na biomassa granulada. Dessa forma, foi necessário calcular a quantidade de LAS adsorvido. Para tanto, foi utilizado à seguinte fórmula.

$$
\mathrm{LAS}_{\text {ads. gran. }}=\alpha \times \beta \times \mathrm{V}
$$

Sendo:

$\mathbf{L A S}_{\text {ads. gran. }}$ = massa de LAS adsorvido nos grânulos do leito do reator EGSB 
$\boldsymbol{\alpha}=$ média da concentração de LAS extraído dos grânulos no leito do reator (mg/gST)

$\boldsymbol{\beta}=$ sólidos totais do reator na Etapa IV $(\mathrm{g} / \mathrm{L})$

$\mathbf{V}=$ volume do reator $(\mathrm{L})$

O resultado da quantidade de LAS adsorvido na biomassa granulada presente no leito do reator foi de $197,55 \mathrm{mg}$ de LAS durante toda a operação do reator.

\subsubsection{Balanço de Massa do SST efluente}

Parte da massa de LAS saiu do sistema adsorvido junto aos sólidos totais presente no efluente. Dessa forma foi calculada a massa de LAS presente no SST efluente da seguinte forma:

$$
\mathrm{LAS}_{\text {ads. }} \text { SST efl. }=\mathrm{A} \times \mathrm{B} \times \mathbf{V}_{\text {efl }}
$$

Sendo:

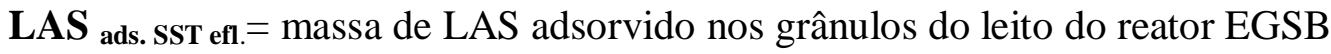

$\mathbf{A}$ = média da concentração de LAS extraído no SST efluente (mg/gST)

B = sólidos totais efluente na etapa IV $(\mathrm{g} / \mathrm{L})$

$\mathbf{V}_{\text {efl }}=$ volume total efluente durante todo o período de operação do reator (L)

O resultado da quantidade de LAS adsorvido nos SST efluente foi de $126,25 \mathrm{mg}$ de LAS durante toda a operação do reator.

\subsubsection{Balanço de Massa Global}

Calculada a massa de LAS afluente, efluente e adsorvido, tanto, no SST efluente, como na biomassa presente dentro do reator foi possível calcular o balanço de massa global de LAS (Tabela 5.10).

Tabela 5.10: Balanço Global de LAS

\begin{tabular}{c|ccc|cc}
\hline $\begin{array}{c}\text { Entrada } \\
(\mathbf{m g})\end{array}$ & $\begin{array}{c}\text { Saída } \\
\text { Efluente }\end{array}$ & $\begin{array}{c}\text { Adsorvido } \\
\text { biomassa do leito } \\
(\mathrm{mg})\end{array}$ & $\begin{array}{c}\text { Adsorvido SST } \\
\text { efluente } \\
(\mathrm{mg})\end{array}$ & $\begin{array}{c}\text { LAS } \\
\text { removido } \\
(\mathrm{mg})\end{array}$ & $\begin{array}{c}\text { Resultado } \\
\text { degradado } \\
(\mathrm{mg})\end{array}$ \\
\hline $3.917,63$ & $1.698,73$ & 197,55 & 126,25 & $2.218,9$ & $1.895,1$ \\
- & $43,4 \%$ & $5,0 \%$ & $3,2 \%$ & $56,6 \%$ & $48,4 \%$ \\
\hline
\end{tabular}


Portanto, 8,2\% de LAS ficaram adsorvidos, 43,4\% foram recuperados no efluente e $48,4 \%$ foram biodegradados (Figura 5.11). Desse modo, 61\% de LAS ficaram adsorvidos na biomassa do leito do reator, enquanto, 39\% ficaram adsorvidos no SST efluente (Figura 5.12). Levando em conta o total de LAS removido, 85,4\% correspondem a biodegradação e 14,6\% por adsorção a biomassa.

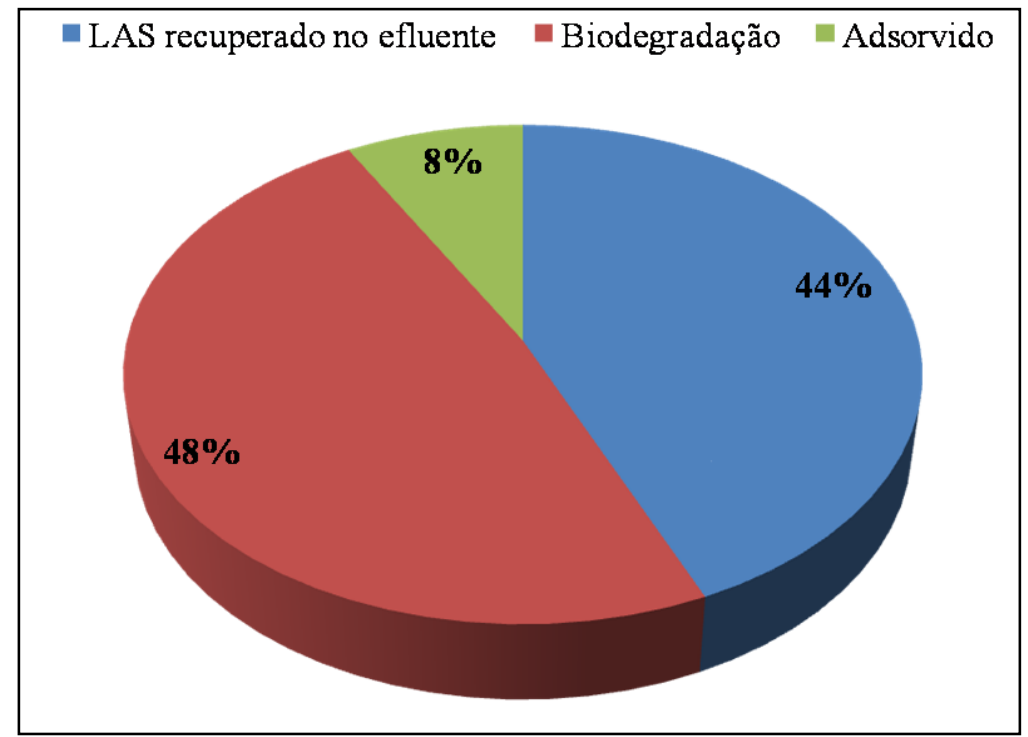

Figura 5.11: Destino do LAS

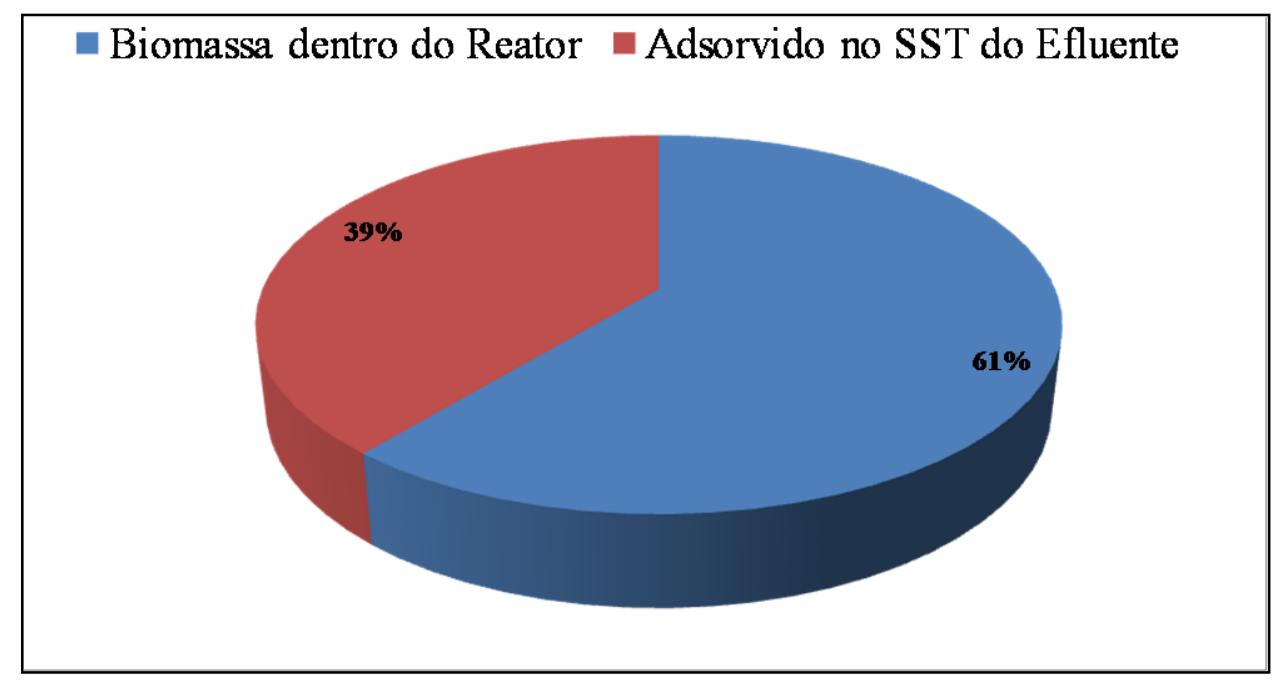

Figura 5.12: Proporção da adsorção do LAS no reator EGSB 


\subsection{Microscopia de Contraste de Fase e Fluorescência}

Ao final de cada etapa de operação do reator EGSB, pequena quantidade de amostra do leito e do copo eram retiradas para os exames microscópicos. Na Tabela 5.11 encontram-se descritas as frequiências das principais morfologias visualizadas nas amostras (Figura 5.13 e Figura 5.14). Pouca diferença morfológica foi observada entre a biomassa do copo e do leito.

Tabela 5.11: Caracterização morfológica da biomassa do leito e copo nas diferentes etapas de operação do reator EGSB.

\begin{tabular}{|c|c|c|c|c|c|}
\hline \multirow{2}{*}{\multicolumn{2}{|c|}{ Morfologia }} & \multicolumn{4}{|c|}{ Etapa } \\
\hline & & $\mathbf{I}$ & II & III & IV \\
\hline \multirow{4}{*}{ Arquéias Metanogênicas } & Methanosarcina sp. & +++ & ++ & ++ & ++ \\
\hline & Methanosaeta sp. & +++ & +++ & +++ & +++ \\
\hline & Bacilos Fluorescentes & + & ++++ & +++ & +++ \\
\hline & Cocos fluorescentes & - & - & - & - \\
\hline \multirow{8}{*}{ Bactérias } & Bacilos & ++++ & ++++ & ++++ & ++++ \\
\hline & Bacilos Curvos & +++ & +++ & +++ & +++ \\
\hline & Cocos & ++ & ++ & ++ & ++ \\
\hline & Cocos em cadeia & - & - & - & - \\
\hline & Endósporo & - & - & - & - \\
\hline & Espiroqueta & - & - & - & - \\
\hline & Filamentos & ++++ & ++++ & ++++ & ++++ \\
\hline & Filamentos septados & +++ & +++ & +++ & +++ \\
\hline
\end{tabular}

Ocorreu pouca variação da diversidade morfológica microbiana durante a operação do reator, mesmo, após a adição do surfactante na Etapa II. Destacou-se a presença constante de bactérias filamentosas, as quais foram relacionadas com a manutenção da estrutura do grânulo; além de filamentosas septadas, bacilos e bacilos curvos. Em relação às arquéias metanogênicas, embora poucos bacilos fluorescentes estivessem presentes ao final da Etapa I, foram predominantes nas etapas seguintes. Sarcinas fluorescentes semelhantes à Methasarcina sp. foram visualizadas com relativa frequiência além de cistos fluorescentes (Figura 5.14f ). Morfologias semelhantes a Methanosaeta sp. também foram observadas em todas as amostras das etapas de operação.

Methanosaeta e Methanosarcina são arquéias pertencentes a família Methanosarcinaceae, conhecidas por serem as únicas a utilizar o acetato como substrato para 
a metanogênse. Methanosarcina pode também utilizar metanol, metilaminas, e $\mathrm{H}_{2}: \mathrm{CO}_{2}$, todavia, Methanosaeta usa exclusivamente acetato. A presença de sarcinas metanogênicas é indicativa de ambiente anaeróbio estrito (ZHILINA, 1972).

Embora, as arquéias metanogênicas, em geral, sejam mais sensíveis a mudanças ambientais e à presença de compostos tóxicos ou inibitórios, em relação às bactérias acidogênicas, é interessante salientar que morfologias semelhantes à tais arquéias foram, também, observadas na biomassa presente no copo do reator. Todavia, a biomassa do copo não apresentava a estrutura granulada que confere proteção a microbiota mais sensível a compostos tóxicos. Tal fato, provavelmente deveu-se, a menor concentração de LAS residual dentro no reator, que durante toda a operação não superou $7 \mathrm{mg} / \mathrm{L}$. Segundo LIU et al. (1985), algumas arquéias metanogênicas, tais como, Methanosarcina mazzei e Methanosarcina acetivorans durante o ciclo de vida podem apresentarem-se na forma de cisto ou possuírem lâmina espessa envolvendo as células cocoides. Tais estruturas conferem resistência a interferentes ambientais como, por exemplo, dessecação.

Segundo, Wagener \& Schink (1987), concentrações iguais ou maiores que $10 \mathrm{mg} / \mathrm{L}$ de LAS em reator anaeróbio de leito fixo, usando água residuária sintética a $28^{\circ} \mathrm{C}$ causou inibição da metanogênese e, conseqüentemente, da microbiota responsável pela sua degradação. Gavala \& Ahring, (2002) operaram reator em batelada com lodo anaeróbio aclimatado ao LAS, por período superior a um ano e TDH de 15 dias. Os autores constataram que as bactérias consumidoras de ácido propiônico foram mais sensíveis à presença de LAS (100 a 150 mg/L), do que as arquéias metanogênicas acetoclásticas. Provavelmente, a inibição causada pelo LAS foi devida à sua interação com as membranas microbianas das bactérias, impedindo o transporte de nutrientes e/ou substrato para dentro das células bacterianas. 


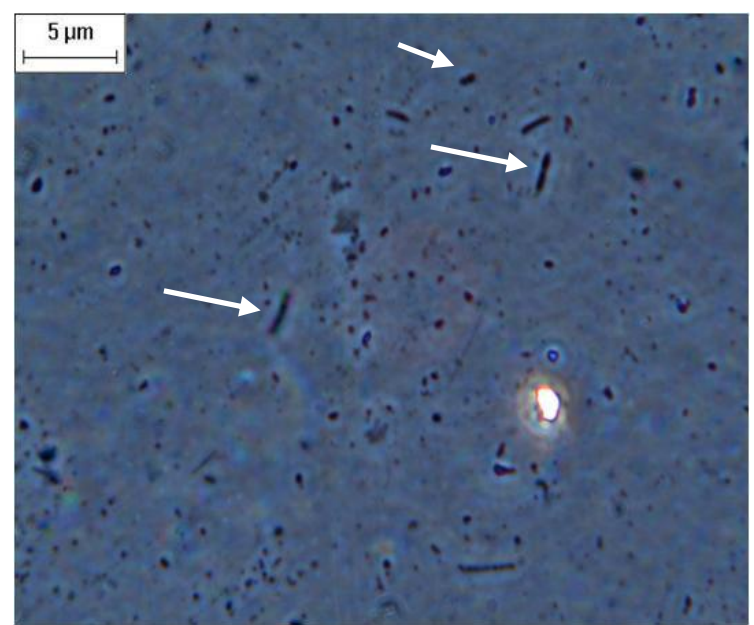

(a)

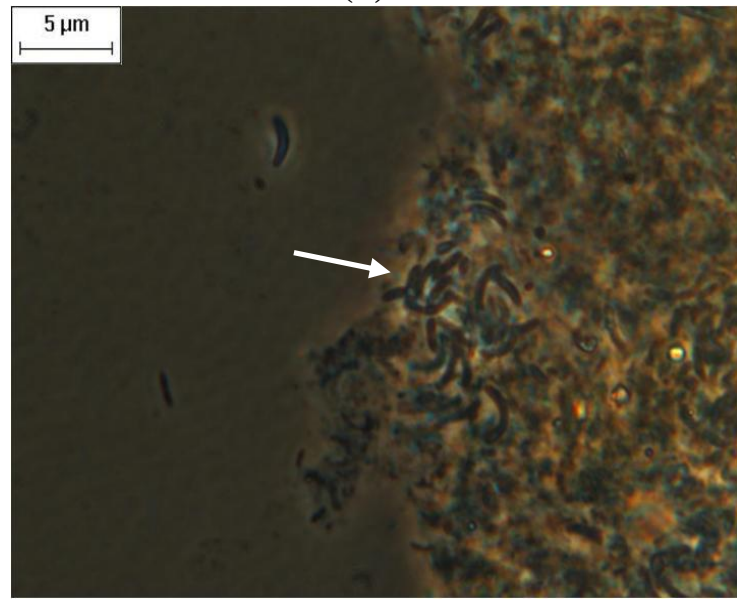

(c)

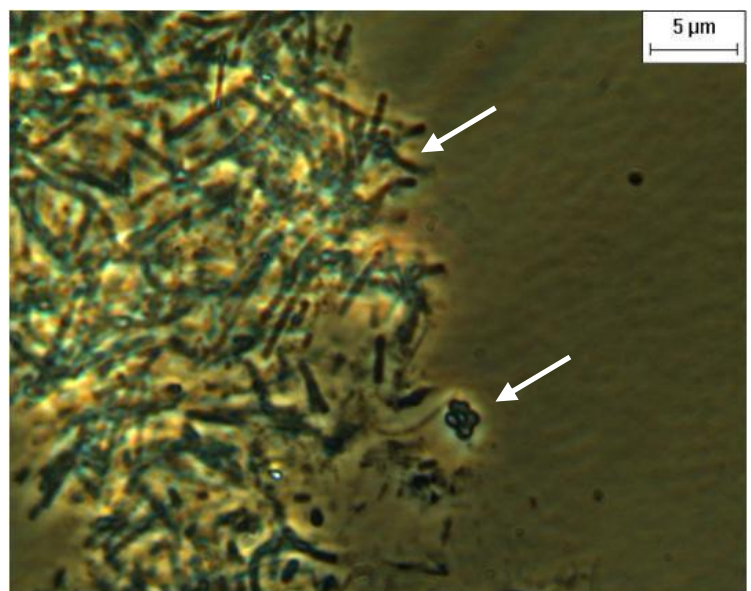

(e)

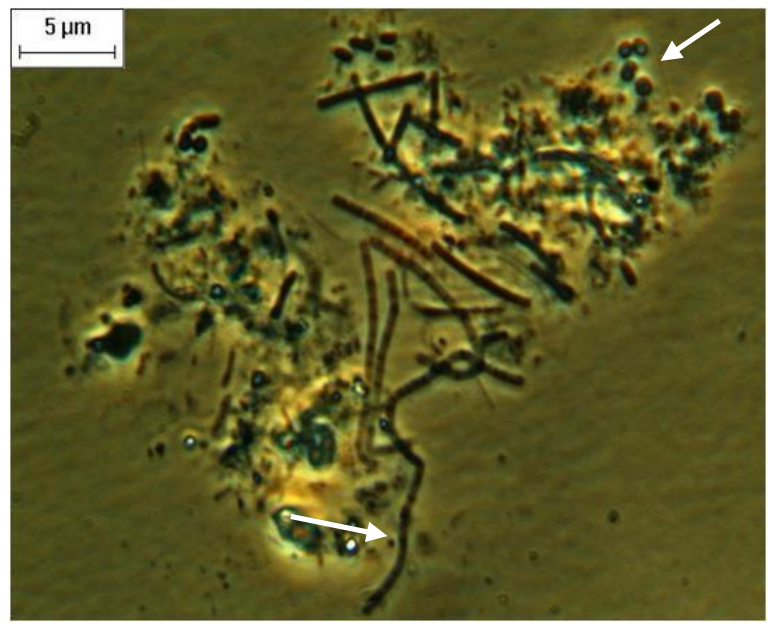

(b)

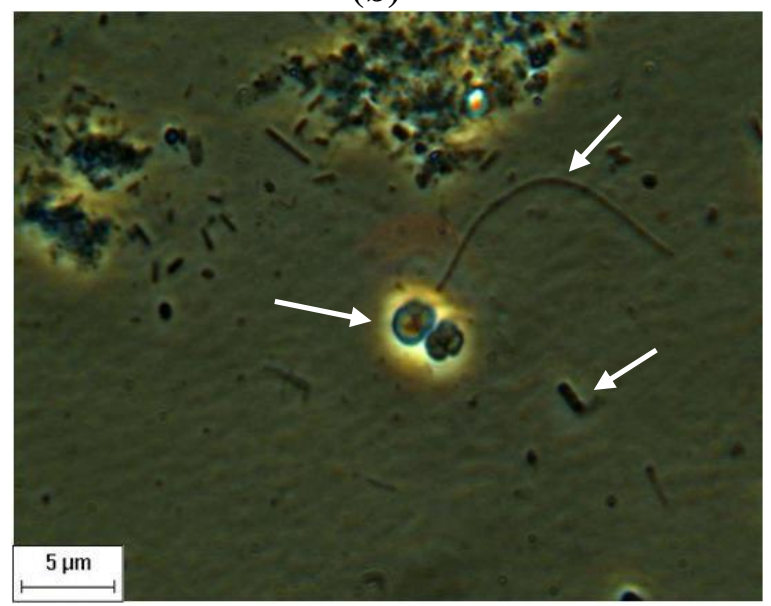

(d)

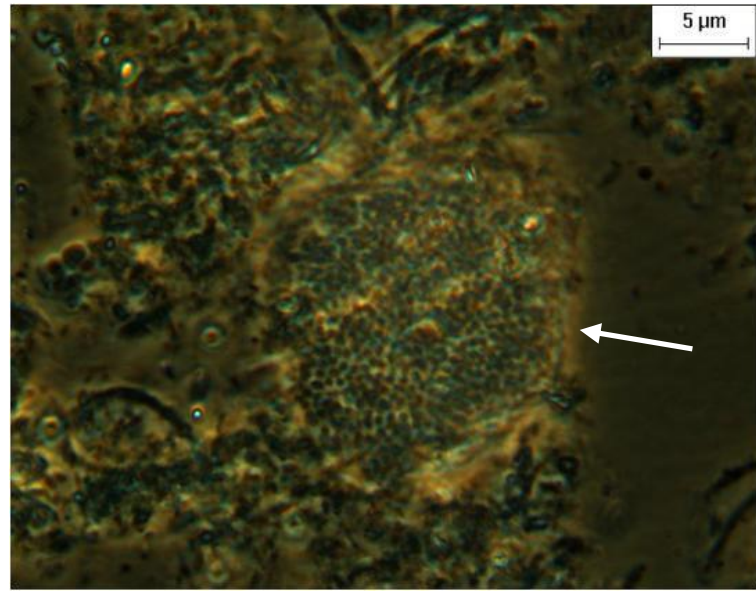

(f)

Figura 5.13: Microscopia de contraste de fase das amostras do reator: (a) bacilos, (b)

filamentos septados, (c) bacilos curvos, (d) sarcinas, (e) sarcinas e bacilos e (f) cistos. 


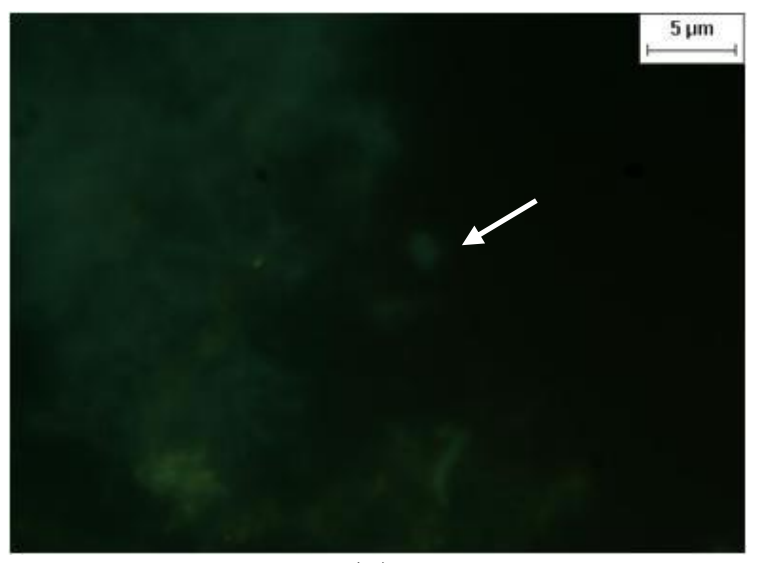

(a)

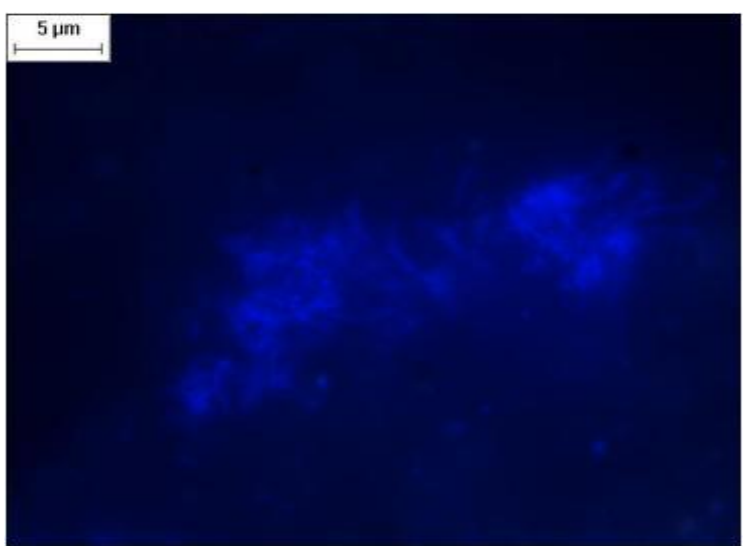

(c)

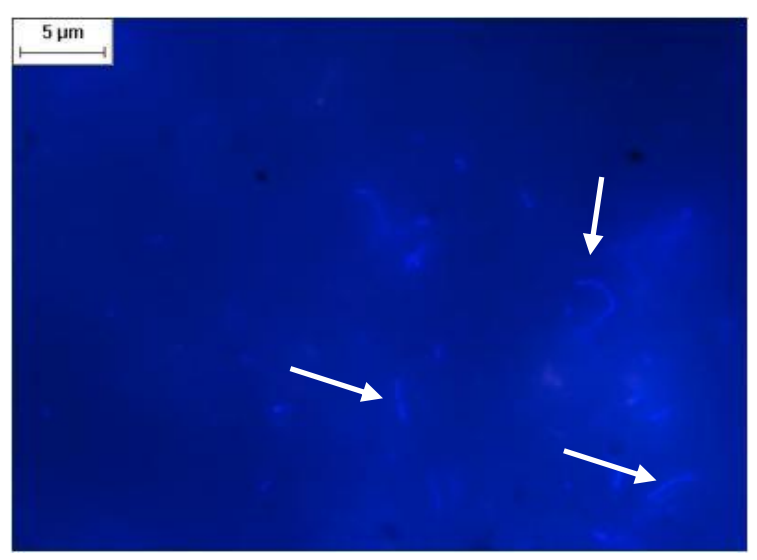

(b)

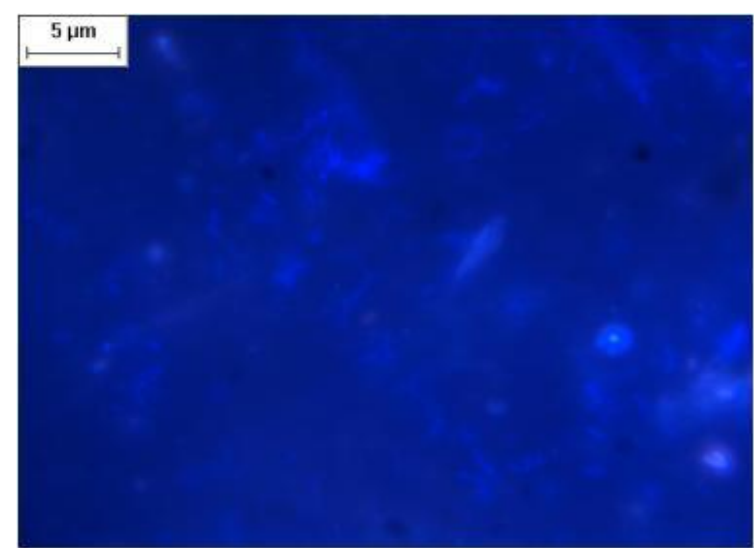

(d)

Figura 5.14: Microscopia de fluorescência das amostras do reator. (a) bacilos fluorescentes e morfologia semelhante a Methanosarcina sp. (b) e (c) bacilos fluorescentes. 


\subsection{Análises Quantitativas}

Na Figura 5.15 e Tabela 5.12 encontra-se descrito resumo dos resultados obtidos em relação às análises quantitativas das populações microbianas presentes no reator EGSB nas diferentes etapas de operação. Nas Etapas I e II ocorreu contaminação dos ensaios e, portanto, tais resultados não foram apresentados. O NMP para as bactérias redutoras de ferro foi realizado apenas na Etapa IV em virtude dos resultados obtidos no sequienciamento da região RNAr 16S das amostras, que indicou bactérias semelhantes a esse grupo microbiano.

Tabela 5.12: NMP das amostras do leito e copo do reator EGSB

\begin{tabular}{ccccccc}
\hline & \multicolumn{5}{c}{ Etapas } \\
Populações Microbianas & Inóculo & III Leito & IV Leito IV Leito - BRF & IV Copo \\
\cline { 2 - 7 } & & \multicolumn{5}{c}{ NMP/gSTV } \\
\hline Arquéias Metanogênicas & $6,6 \times 10^{6}$ & $4,0 \times 10^{4}$ & $1,4 \times 10^{7}$ & $1,1 \times 10^{4}$ & $2,5 \times 10^{6}$ \\
Bactérias Anaeróbias Totais & $6,6 \times 10^{9}$ & $4,7 \times 10^{12}$ & $2,5 \times 10^{10}$ & $2,5 \times 10^{10}$ & $2,5 \times 10^{11}$ \\
Bactérias Redutoras de Ferro & - & - & - & $2,1 \times 10^{9}$ & - \\
Metanogênicas/Anaeróbias (\%) & $1,0 \times 10^{-1}$ & $1,0 \times 10^{-6}$ & $5,6 \times 10^{-2}$ & $4,4 \times 10^{-5}$ & $1,0 \times 10^{-3}$ \\
\hline
\end{tabular}

Os resultados obtidos de NMP para o inóculo foram os seguintes: 6,6×10 $10^{6} \mathrm{NP} / \mathrm{gSTV}$ de arquéias metanogênicas e 6,6×10 $\mathrm{NMP} / \mathrm{gSTV}$ de bactérias anaeróbias totais.

A Etapa III caracterizada por TDH médio de 26 horas, carga específica de LAS de

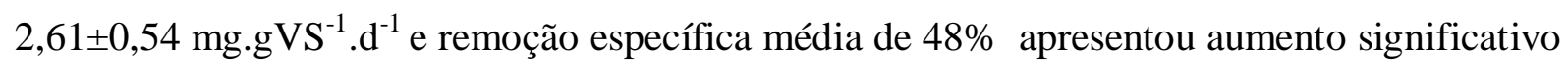
de bactérias anaeróbias totais e diminuição das arquéias metanogênicas. $\mathrm{O}$ aumento das bactérias anaeróbias totais pode estar relacionado com a adaptação desses microrganismos as condições do reator. Além disso, a remoção do LAS está associada aos microrganismos do domínio Bacteria. A sensibilidade das arquéias metanogênicas ao surfactante LAS já foi constatada por outros autores, tais como, Mösche \& Meyer (2001) e Gavala \& Ahring (2002).

A Etapa IV foi caracterizada pela remoção de $64 \%$ de LAS com carga específica de 1,45 mg.gVS${ }^{-1} \cdot \mathrm{d}^{-1}$ e TDH de 32 horas. Os valores de bactérias anaeróbias totais e arquéias metanogênicas para o leito foram maiores aos encontrados no inóculo. Quando comparamos, a quantidade de arquéias metanogênicas com a Etapa III (4,0 x 10 ${ }^{4} \mathrm{NMP} / \mathrm{g}$ STV) foi possível observar aumento acentuado na Etapa IV (1,4 x $10^{7} \mathrm{NMP} / \mathrm{g}$ STV). Esse resultado pode estar relacionado com a carga de LAS aplicada que variou entre essas duas etapas (III e IV) influenciando na proporção das comunidades microbianas. 
Todavia, o NMP realizado com a biomassa presente no copo do reator durante a Etapa IV (Figura 5.15 - IV Copo) apresentou diminuição da quantidade de arquéias metanogênicas $\left(2,5 \times 10^{6} \mathrm{NMP} / \mathrm{g}\right.$ STV $)$ e aumento da quantidade de bactérias anaeróbias totais $\left(2,5 \times 10^{11}\right.$ NMP/g STV) quando comparadas com as amostras do leito da Etapa IV.

A diminuição das arquéias metanogênicas condiz com os resultados obtidos de outros autores, que retratam a sensibilidade desse grupo ao LAS. Para entender o aumento da quantidade de bactérias anaeróbias totais por grama de sólidos totais voláteis no copo é interessante ressaltar que a biomassa presente no copo foi depositada ao longo da operação do reator, devido ao cisalhamento dos grânulos em virtude do LAS afluente e da alta velocidade ascensional efluente. Portanto, no copo ocorreu diminuição do diâmetro médio dos grânulos ao longo da operação reduzindo a presença de arquéias metanogênicas (Tabela 5.6). 


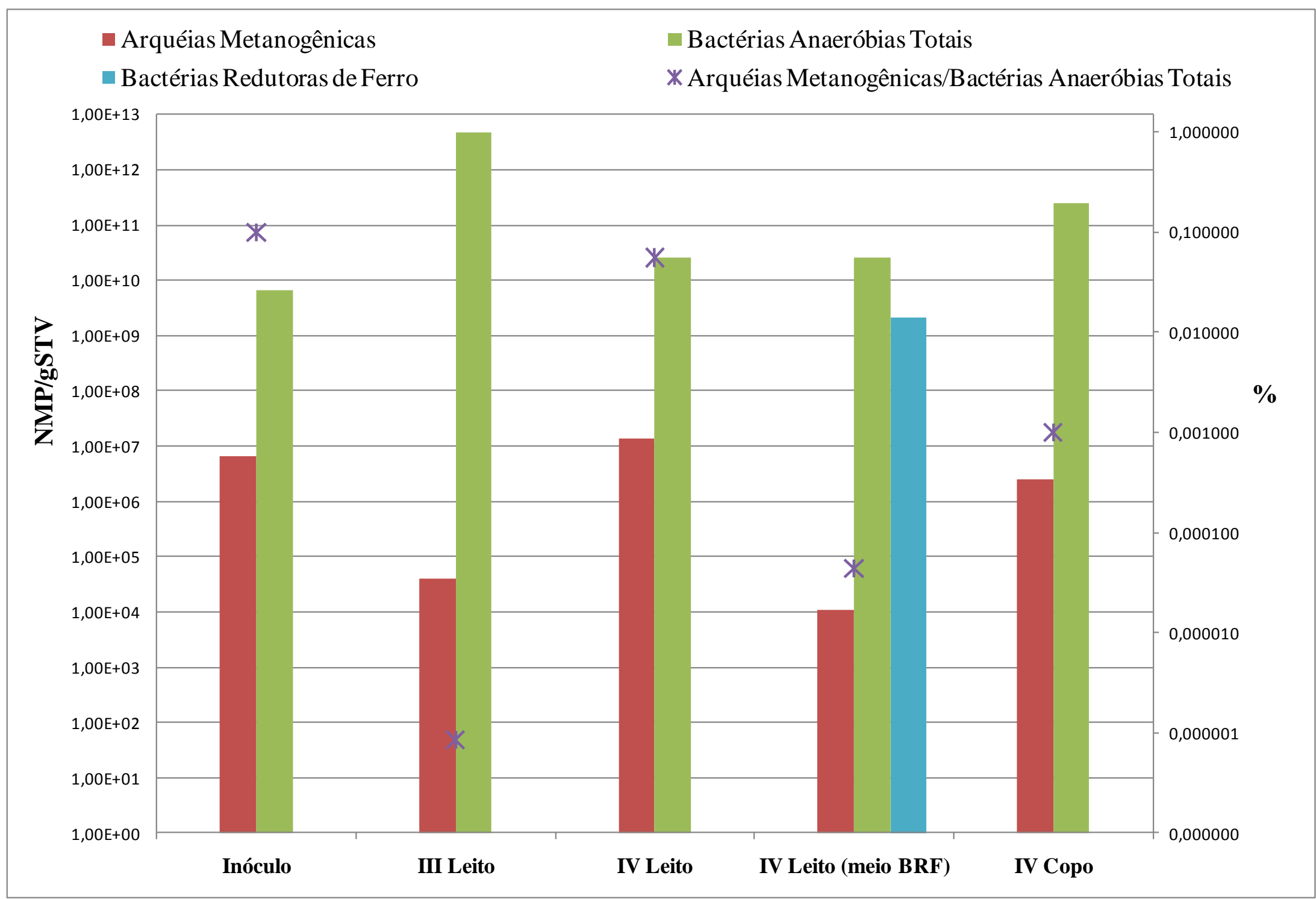

Figura 5.15: Analise quantitativa das populações microbianas 
Macleod et al. (1990) propuseram que a estrutura do grânulo pode ser dividida em três camadas distintas, a mais interna corresponde as arquéias metanogênicas que podem agir como centros de nucleação, seguido por bactérias que utilizam e produzem $\mathrm{H}_{2}$ e, por último, na região mais externa bactérias filamentosas, além de cocos e bacilos. Portanto, a predominância de bactérias anaeróbias totais, provavelmente, foi devido ao desprendimento de parte da biomassa externa do grânulo que, devido a alta velocidade ascensional foi carreada para a região superior do reator (copo).

O NMP da Etapa IV com amostra do Leito (meio para Bactérias Redutoras de Ferro) foi realizado com meio específico para favorecer o crescimento de bactérias redutoras de ferro. Além de estimar a quantidade de bactérias redutoras de ferro foi estimada, também, a quantidade de arquéias metanogênicas. Comparando os resultados (Etapa IV Leito e Etapa IV Leito com meio BRF) foi possível observar diminuição das arquéias metanogênicas. Embora a utilização de meios distintos possa resultar em padrões quantitativos distintos, a competição entre as bactérias redutoras de ferro e arquéias metanogênicas pode ser a explicação mais plausível.

A utilização de Ferro III como aceptor final de elétrons para oxidação da matéria orgânica é termodinamicamente mais favorável do que a mineralização da matéria orgânica com redução de sulfato ou produção de metano (RODEN et al., 2000). Tal fato explica a diminuição de arquéias metanogênicas utilizando meio enriquecido com Ferro III, uma vez que a detecção é feita a partir da presença ou ausência de metano no headspace. A quantidade de bactérias redutoras de ferro III encontrada foi de $2,1 \times 10^{9}$ $\mathrm{NMP/gSTV}$, ou seja, $8 \%$ das bactérias anaeróbias totais presente.

Oliveira (2010) estudou a remoção de LAS em reator de leito fluidificado em escala de bancada com areia e obteve os seguintes resultados: $3,98 \times 10^{10} \mathrm{NMP} / \mathrm{gSTV}$ de bactérias anaeróbias totais, $3,75 \times 10^{9} \mathrm{NMP} / \mathrm{gSTV}$ de bactérias redutoras de sulfato e $1,93 \times 10^{4} \mathrm{NMP} / \mathrm{gSTV}$ de arquéias metanogênicas para $46 \mathrm{mg} / \mathrm{L}$ de LAS afluente e $93 \%$ de remoção. A alimentação utilizada pela autora foi substrato sintético contendo extrato de levedura e sacarose. O extrato de levedura na sua constituição apresenta aminoácidos que contem enxofre na sua composição, isso pode ter favorecido o aparecimento de BRS fato este não observado nesse estudo. Assim como, nesse estudo, Oliveira (2010) também observou que menos de $1 \%$ das bactérias anaeróbias totais eram arquéias metanogênicas.

As principais morfologias encontradas no NMP nas diferentes etapas e para as diferentes populações estão apresentadas na Figura 5.16. Em todos os casos a 
visualização de arquéias metanogênicas foi esporádica e em baixa quantidade, tal fato está relacionado à baixa quantidade desse grupo microbiano. A morfologia predominante foi bacilos sendo detectadas com menores freqüências estruturas celulares na forma de cocos.

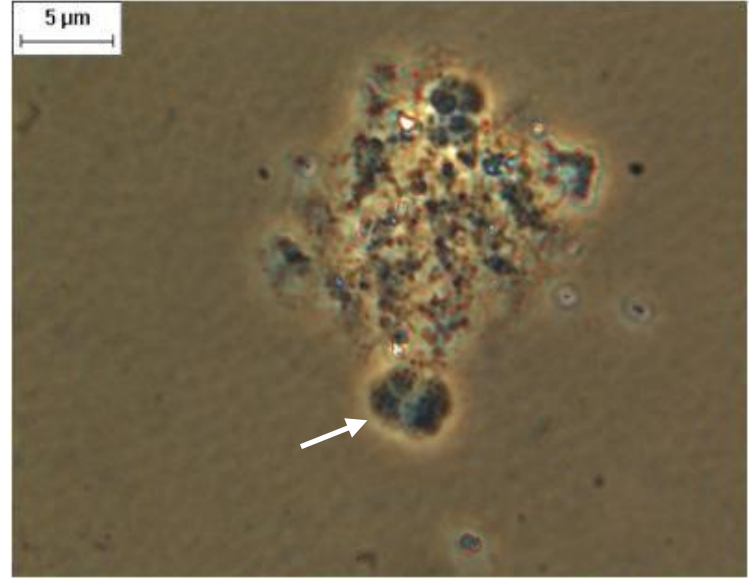

(a)

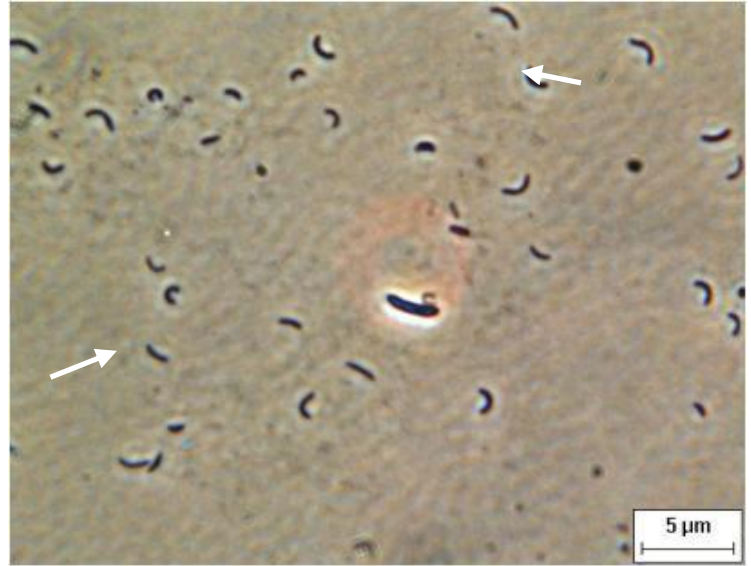

(c)

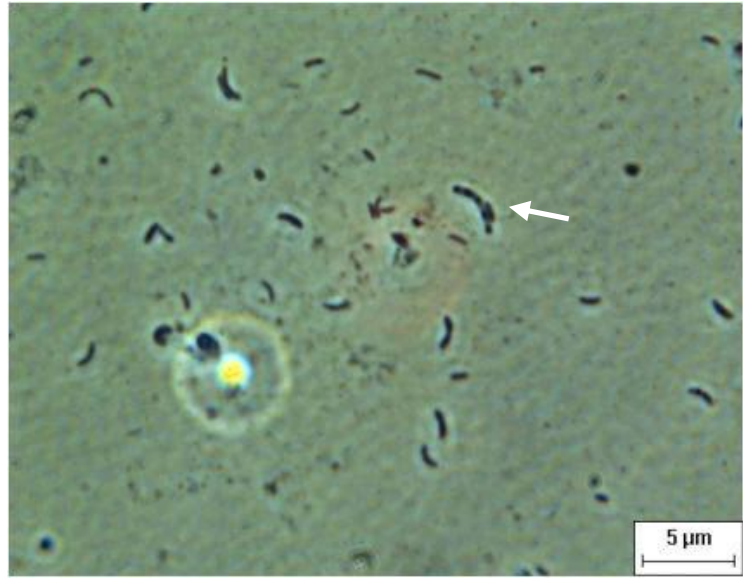

(b)

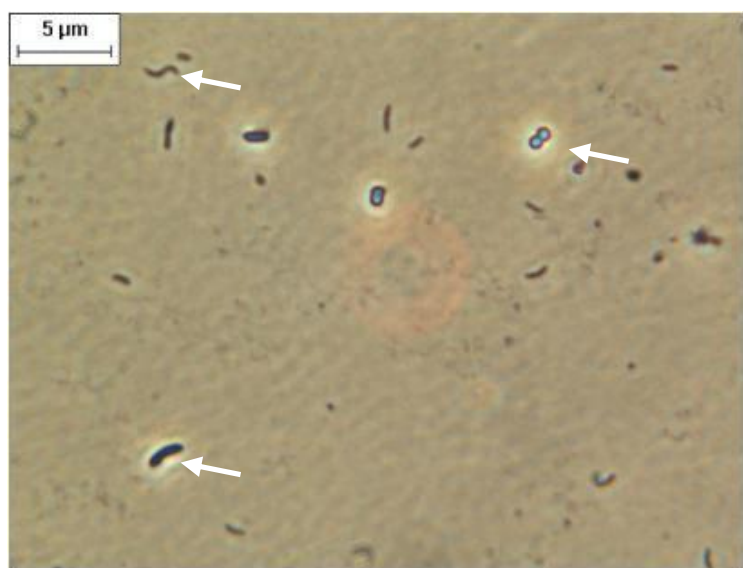

(d)

Figura 5.16: Microscopia de Contraste de Fase do NMP. (a) Sarcinas, (b) e (c) bacilos curvos e (d) bacilos, diplococos e espirilo.

Portanto, a adição do surfactante reduziu a população de arquéias metanogênicas durante a operação do reator EGSB. Todavia, a quantidade de bactérias anaeróbias totais foi relativamente estimulada, quando, comparada com o inóculo e entre as etapas do reator. 


\subsection{Análise Qualitativa}

Para a amostra retirada do leito e da região do copo do reator foram obtidos 111 e 59 clones, respectivamente. Os fragmentos seqüenciados tiveram tamanho médio de 600 pares de bases (pb). Na Tabela 5.13 encontram-se descritas as proporções dos filos encontrados em cada região do reator. Ressalta-se que as amostras foram retiradas na

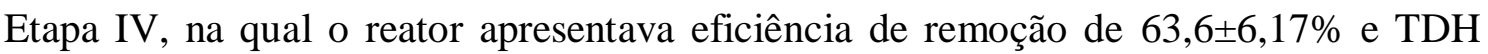
médio de 32 horas.

Tabela 5.13: Proporção dos filos encontrados em cada amostra*

\begin{tabular}{ccc}
\hline $\begin{array}{c}\text { Clones do Leito } \\
\text { \% }\end{array}$ & Filos & Clones do Copo \\
\hline 0,0 & Acidobacteria & \% \\
\hline 0,0 & OP10 & 3,4 \\
0,9 & Verrucomicrobia & 3,4 \\
0,9 & Bacteroidetes & 0,0 \\
19,8 & Synergistetes & 1,7 \\
1,8 & Firmicutes ** & 13,6 \\
\hline 52,3 & Proteobacteria ** & 35,6 \\
\hline 24,3 & Não Classificada & 15,3 \\
\hline *Resultados obtidos utilizando Library & Compare Versão 2.2 - Ribosomal database Project, $95 \%$ de \\
confiança & & \\
** diferença significativa & & \\
\hline
\end{tabular}

As proporções entre os filos foram diferentes em cada região do reator. Diferença significativa foi observada para os filos Firmicutes e Proteobacteria, quando comparada as duas bibliotecas. Na biomassa retirada do leito foi possível observar que os filos predominantes foram Proteobacteria $(52,3 \%)$ e Synergitetes $(19,8 \%)$. Todavia, na amostra retirada da região do copo do reator, os filos predominantes foram Firmicutes $(35,6 \%)$ e Proteobacteria $(15,3 \%)$.

Em relação ao filo Proteobacteria, a classe Deltaproteobacteria foi a que apresentou maior proporção com $39,6 \%$ dos clones da região do leito, e apenas 8,5\% dos clones para a região do copo (Tabela 5.14). 
Tabela 5.14: Proporção de classes do filo Proteobacteria em cada amostra*

\begin{tabular}{ccc}
\hline $\begin{array}{c}\text { Clones do Leito } \\
\text { \% }\end{array}$ & Classes & Clones do Copo \\
\hline 6,3 & Betaproteobacteria & 6,8 \\
39,6 & Deltaproteobacteria** & 8,5 \\
7,2 & Epsilonproteobacteria & 0 \\
0,9 & Não classificada & 0 \\
\hline *Resultados obtidos utilizando Library Compare Versão 2.2 - Ribosomal database Project, $95 \%$ de \\
confiança \\
** diferença significativa
\end{tabular}

A única classe encontrada no filo Firmicutes foi Clostridia, ordem Clostridiales, famílias (Incertae Sedis XIII, Veillonellaceae e não classificados). O gênero majoritário foi Sporomusa presente apenas na região do copo do reator.

O reator EGSB por ser de mistura completa e, devido a diluição afluente, não ocorre estratificação do meio nutricional e/ou concentração de LAS. Dessa forma, as diferenças quando comparadas as duas bibliotecas não estão relacionados com as disponibilidades nutricionais. Entretanto, pode estar relacionado com a origem da biomassa na região do copo que foi devido ao desprendimento de porções da região externa do grânulo, em virtude da alta velocidade ascensional do efluente e a toxicidade do surfactante. Além disso, a turbulência pode ter agido como fator seletivo, uma vez que a região do leito apresentava alta turbulência em função da necessidade de expansão do leito granulado, situação oposta em relação aquela encontrada na região do copo do reator.

Na Tabela 5.15 encontra-se comparação dos filos encontrados nesse trabalho e aqueles obtidos por outros autores que estudaram a remoção anaeróbia de LAS em configurações distintas de reatores.

É interessante notar que alguns filos foram constantes nas diferentes configurações de reatores, entre eles, foram constatados Firmicutes e Proteobacteria. O filo Proteobacteria foi observado nesse trabalho, em Oliveira et al. (2010) e Duarte et al. (2010). Todavia, as classes predominantes em cada trabalho foram distintas. Oliveira et al. (2010) constataram similaridade de bactérias com a classe Betaproteobacteria. Nesse trabalho, foi observada similaridade de microrganismos relacionados a classe Deltaproteobacteria. Duarte et al. (2010) encontram semelhança com microrganismos da classe Alfaproteobacteria. Provavelmente, as diferenças encontradas entre os 
trabalhos citados podem ser atribuídas às distintas configurações de reatores, características hidráulicas, composição nutricional e origem do inóculo.

Em contrapartida, os filos Synergistetes e OP 10 foram exclusivos desse trabalho. Filo OP10 foi detectado em Obsidian, Yellowstone National Park, em 1994. Desde então, centenas de RNAr 16S tem sido atribuído similaridade a OP10 de amostras provenientes de ampla variedade de ambientes, incluindo instalações geotérmicas, ambientes hipersalinos, entre outros. Estudos preliminares indicam que tais microrganismos são abundantes e amplamente distribuídos na natureza e diversos filogeneticamente (HARRIS et al., 2004).

O filo Synergistetes, foi descrito por Jumas-Bilak et al., (2009). As bactérias pertencentes a esse filo são encontradas em ampla gama de habitats anaeróbios, tais como, em resíduos de sistema de tratamento de água, solos, poços de petróleo e relacionados a doenças periodontais. São bacilos Gram-negativos e fermentam aminoácidos. Essa característica é comum para a maioria dos membros desse filo, aparentemente essa uniformidade pode indicar que apenas os membros pertencentes a esse filo exploram esse nicho em diferentes ambientes.

Tabela 5.15: Proporção dos filos encontrados em alguns trabalhos sobre remoção de LAS em diferentes configurações de reatores

\begin{tabular}{|c|c|c|c|c|c|}
\hline \multirow[t]{2}{*}{ Filos } & $\begin{array}{l}\text { Oliveira et al. } \\
\quad(2010)^{1}\end{array}$ & $\begin{array}{c}\text { Nesse } \\
\text { trabalho } \\
\text { Leito }^{2}\end{array}$ & $\begin{array}{c}\text { Nesse } \\
\text { trabalho } \\
\text { Copo }^{2}\end{array}$ & $\begin{array}{l}\text { Duarte et al. } \\
\quad(2010)^{3}\end{array}$ & $\begin{array}{c}\text { Duarte } e t \\
\text { al. } \\
(2010)^{4}\end{array}$ \\
\hline & \multicolumn{5}{|c|}{$\%$} \\
\hline Acidobacteria & 3 & 0 & 3,4 & 0 & 5 \\
\hline Actinobacteria & 0 & 0 & 0 & 0 & 2 \\
\hline Bacteriodetes & 42 & 0,9 & 1,7 & 0 & 35 \\
\hline Firmicutes & 2 & 1,8 & 35,6 & 81 & 3 \\
\hline Gemmatimonadetes & 1 & 0 & 0 & 0 & 0 \\
\hline Não classificados & 5 & 24,3 & 27,1 & 0 & 13 \\
\hline OP10 & 0 & 0 & 3,4 & 0 & 0 \\
\hline Proteobacteria & 44 & 52,3 & 15,3 & 19 & 18 \\
\hline Synergistetes & 0 & 19,8 & 13,6 & 0 & 0 \\
\hline Verrucomicrobia & 4 & 0,9 & 0 & 0 & 11 \\
\hline Fibrobacteres & 0 & 0 & 0 & 0 & 8 \\
\hline Chlorobi & 0 & 0 & 0 & 0 & 3 \\
\hline Chloroflexi & 0 & 0 & 0 & 0 & 2 \\
\hline
\end{tabular}


1 Reator de leito fluidificado com TDH 18 horas e areia como material suporte. Alimentação substrato sintético acrescido de 46 mgLAS/L. Remoção de LAS de $93 \%$.

2 Reator EGSB com TDH de 32 horas. Alimentação meio mineral modificado, solução de vitaminas, bicarbonato de sódio e 14 mgLAS/L. Remoção de LAS de $63 \%$.

3 Reator Anaeróbio Horizontal de leito fixo (RAHLF) preenchidos com espuma de poliuretano com TDH de 12 horas . Alimentação constituída de extrato de levedura, sacarose, sais, bicarbonato de sódio e 14 mgLAS/L. Remoção de LAS de $56 \%$.

4 Reator operado em bateladas seqüenciais, contendo biomassa granular. Alimentação consistiu de substrato sintético e 22mgLAS/L. Remoções de 53\% na ausência de co-substrato.

Na Figura 5.17 estão apresentadas as proporções das famílias encontradas em ambas às regiões do reator (Leito e Copo). Notou-se que algumas famílias foram exclusivas da região do leito, tais como, Syntrophobacteraceae, Syntrophomonadaceae, Solirubrobacterales, Peptococcaceae, Incertae Sedis XI, Incertae Sedis XIII, Desulfomicrobiaceae e Anaerolineaceae. Todavia, a região do copo, também, apresentou famílias exclusivas, tais como, Nautiliaceae, Incertae Sedis XII, Holophagaceae, Gracilibacteraceae e Desulfarculaceae. Tal fato pode evidenciar menor diversidade na amostra presente na região do copo quando comparada com a amostra retirada do leito.

$\mathrm{Na}$ amostra retirada do leito existiu predominância da família Desulfuromonadales (27,9\%), seguido da família Synergitaceae (18,9\%), Rhococyclaceae $(5,45 \%)$ e não classificadas $(29,8 \%)$. Na amostra da região do copo notou-se predominância da família Veillonellaceae $(35,6 \%)$, Synergistaceae $(11,9 \%)$ e não classificadas $(35,5 \%)$. 


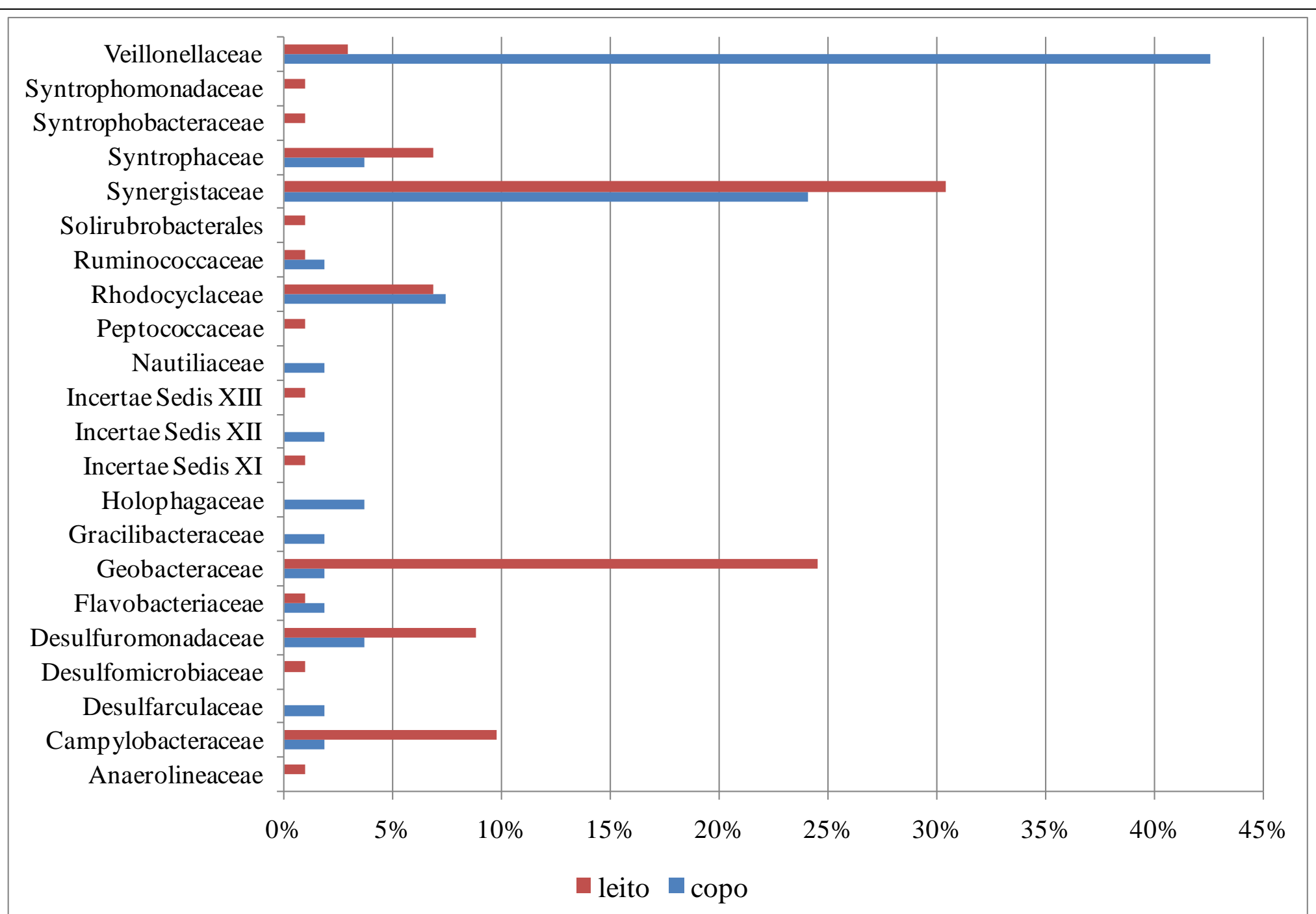

Figura 5.17: Porcentagem dos clones da região do copo e leito relacionados as diferentes famílias com base nos dados RDP classifier, 95\% de confiança 
As bactérias pertencentes à família Geobacteraceae e Holophagaceae em especial, Geobacter (2\% dos clones do Copo e $25 \%$ dos clones do Leito) e Geotrix (4\% dos clones do Copo e ausentes no Leito), respectivamente, são pertencentes ao grupo de bactérias redutoras de ferro. Tal resultado corrobora com os valores obtidos no NMP, uma vez que $8 \%$ das bactérias anaeróbias totais foram representadas por bactérias redutoras de ferro na etapa IV, na qual foi realizado o NMP para BRF e retirada de amostra para análises filogenéticas.

Microrganismos redutores de ferro são conhecidos desde 1920, mas apenas depois de isolado por Lovley et al., (1987), seu metabolismo foi estudado com mais detalhe. Bactérias semelhantes a Geobacter são bacilos quimioorganotróficos estritamente anaeróbios, Gram-negativos, não formadores de endósporos. Podem oxidar completamente ácido acético, etanol, ácido propiônico, ácido butírico, ácido isobutírico, ácido valérico, ácido isovalérico, ácido pirúvico, propanol, butanol, tolueno, benzeno, benzaldeído, benzilálcool, $p$-hidroxibenzoato, $p$-hidroxibenzialcool, fenol e $p$-cresol a dióxido de carbono, com redução do Ferro III. Provavelmente, parte da degradação da molécula de LAS pode ser atribuída a esse gênero diante da sua versatilidade metabólica.

Como pode ser observado na Tabela 4.3, na composição do meio mineral não há presença de Ferro III, todavia, adicionava-se ferro II $\left(\mathrm{FeCl}_{2} \cdot 4 \mathrm{H}_{2} \mathrm{O}\right)$. Provavelmente, durante a alimentação, devido à instabilidade do ferro II ocorreu oxidação para Ferro III. Todavia, a concentração adicionada foi baixa $(2 \mathrm{mg} / \mathrm{L})$, dessa forma, os microrganismos redutores de ferro atuaram como quimioorganotróficos e não como redutores de ferro.

COATES et al., 2001 isolaram de aqüífero contaminado com hidrocarboneto, na zona de redução de Ferro III, bactérias semelhantes a Geotrix. Bactérias semelhantes a esse gênero foram verificadas somente na biomassa do Copo do reator. Destacam-se por serem bacilos estritamente anaeróbios, não formadores de endósporos, quimioorganotróficos, que oxidam acetato e compostos aromáticos, com redução do Ferro III. Tais bactérias, provavelmente, usaram LAS e ferro III, como aceptor de elétrons.

A família Desulfuromonadaceae em especial Pelobacter (4\% dos clones do Copo e 9\% do Leito), corresponde a bacilos Gram-negativos estritamente anaeróbios, não formadores de endósporo, que usam número muito limitado de substratos. Podem oxidar benzeno e trihidroxibenzeno como fonte de energia. São comumente encontrados 
em áreas contaminadas com metais pesados e hidrocarbonetos (WAGENER \& SCHINK, 1987). Pelobacter venetianus tem a capacidade de degradar polietilenoglicóis e surfactantes não-ionicos (Wagner \& Schink, 1987). Embora, o LAS seja um surfactante aniônico possui as mesmas propriedades anfipáticas dos surfactantes nãoiônicos. Desse modo, sua presença no reator justifica-se, provavelmente devido a utilização de LAS. É interessante notar que bactérias semelhantes a esse gênero esteviveram presentes, tanto na região do Copo (4\% dos clones), como no Leito (9\% dos clones) levando a crer que parte da remoção do LAS estava ocorrendo em grande proporção na região do Leito, mas também na região do Copo.

A família Veillonellaceae, com destaque para Sporomusa apresentou similaridade com $43 \%$ dos clones do Copo e apenas $3 \%$ dos clones do Leito. São bactérias anaeróbias, homoacetogênicas, Gram-negativas e formadoras de endósporos. Realizam reações de metoxilação de compostos aromáticos (BREZNAK et al., 1988). A formação de endósporos é comum em bactérias Gram-positivas, todavia, pode ser encontrado em alguns representantes Gram-negativos, tais como, Sporomusa. A predominância na região do Copo do reator pode estar relacionada a sua característica metabólica, uma vez que são homoacetogênicas, ou seja, utilizam $\mathrm{CO}_{2}$ como aceptor final de elétrons e hidrogênio, para a formação de ácido acético.

Entretanto, termodinamicamente essa rota metabólica é rara de acontecer, uma vez que bactérias homoacetogênicas competem com as metanogênicas pelo hidrogênio, todavia, na região do Copo foi observada menor concentração (NMP/gSTV) de arquéias metanogênicas. Desse modo, a região do copo foi ambiente mais propício para o desenvolvimento desse grupo microbiano em relação a região do Leito do reator. Além disso, parte do $\mathrm{CO}_{2}$ produzido no EGSB encontrava-se no headspace, na região do Copo do reator, tornando disponível para esse grupo microbiano em função da alta solubilidade desse gás. A diminuição das arquéias metanogênicas como consequiência da toxicidade ao LAS favoreceu a predominância de bactérias semelhantes a esse gênero.

$\mathrm{Na}$ família Rhodocyclaceae (7\% dos clones Copo e $7 \%$ do Leito) foram observadas similaridades com Azonexus, Dechloromonas e Azospira. São bactérias aeróbias ou desnitrificantes e Gram-negativas. Em especial, Dechloromonas aromática, tem a capacidade de degradar compostos aromáticos como tolueno, benzoato e clorobenzeno. Dessa forma, sua presença no reator pode estar relacionada ao processo de degradação de compostos aromáticos. 
Em relação a família Syntrophaceae (4\% dos clones do Copo e 7\% do Leito) foi observada semelhança com Smithella. São bactérias que crescem preferencialmente em condições fermentativas-metanogênicas, ou seja, a mesma imposta nesse presente estudo. São bacilos Gram-negativos, estritamente anaeróbios que crescem em sintrofismo com as arquéias metanogênicas. Esse gênero apresenta importante função de metabolizar o excesso de ácido propiônico, um intermediário da fermentação, uma vez que, seu excesso acarreta na inibição da digestão anaeróbia (LIU et al., 1999). Provavelmente, sua baixa porcentagem relativa dentre o número total de clones esteja relacionado as baixas concentrações desse ácido encontradas durante a operação do EGSB.

Na família Anaerolineaceae ( $1 \%$ dos clones e exclusivos da região do leito) foi observada semelhança com Longilinea. São bactérias filamentosas Gram-negativas, sem mobilidade, não formadora de endósporos que crescem em condição estritamente anaeróbia numa faixa de temperatura entre $20^{\circ} \mathrm{C}$ e $50^{\circ} \mathrm{C}$, sendo $\mathrm{pH} 7$ ótimo de crescimento (YAMADA et al., 2006). Segundo esses autores, essas bactérias são comumente observadas na superfície de grânulos de tratamento de água residuária contendo carboidratos. A sua presença exclusivamente na região do Leito é compatível com a presença de grânulos estruturalmente intactos nessa região, uma vez que na região do Copo encontravam-se apenas porções de biomassa resultante do cisalhamento dos grânulos do Leito. Destaca-se que o reator durante toda a operação apresentou pH próximo da neutralidade e $30^{\circ} \mathrm{C}$ de condição térmica corroborando com seu crescimento no reator.

Aproximadamente, $10 \%$ do total de clones do leito e $2 \%$ do Copo apresentaram similaridade com a Família Campylobacteraceae, especificamente semelhante a Arcobacter. Bactérias pertencentes a esse gênero são bacilos Gram-negativos, não formadores de endósporos, presentes em carcaças de frango (HOUF et al., 2005). Tal fato, no presente estudo está relacionado diretamente com o inóculo que foi oriundo de abatedouro de aves. $\mathrm{O}$ crescimento ideal ocorre entre 15 e $37^{\circ} \mathrm{C}$ em condições de microaerofilia ( $3 \%$ de $\mathrm{O}_{2}$ ). Esse fato justifica sua presença majoritária no Leito uma vez que a alimentação apresentava $\mathrm{O}_{2}$ dissolvido que foi rapidamente consumido, e corrobora com a anaerobiose do sistema indicando que a região do Copo do reator apresentava-se, também, em anaerobiose estrita.

Aproximadamente $6 \%$ do total de clones foram relacionados com bactérias redutoras de enxofre (BRS). A semelhança foi relacionada com Desulfarculus, 
Desulfomicrobium, Lebetimonas, Desulfoglaeba e Gracilibacter. Mesmo em baixas concentrações de compostos de enxofre, no reator, não ultrapassando $2,29 \pm 1,26 \mathrm{mg} / \mathrm{L}$ de sulfato e $0,275 \pm 1,3 \mathrm{mg} / \mathrm{L}$ de sulfeto, essas bactérias encontraram ambiente propicio para o crescimento. Provavelmente, utilizaram grupo sulfonado da molécula de LAS, como fonte de enxofre, além de possíveis impurezas de compostos de enxofre resultado do processo de fabricação do LAS. Podem estar presentes no inóculo (abatedouro de aves) em virtude de grande quantidade de aminoácidos que contem enxofre na sua composição.

Todos os gêneros citados são microrganismos estritamente anaeróbios que crescem em condições mesofílicas. Em especial, Desulfoglaeba pode oxidar $n$-alcanos, hidrocarbonetos alifáticos saturados lineares ou ramificados, (Davidova et al., (2006), que se assemelham a cadeia alquílica linear da molécula de LAS.

A família Peptococcaceae (1\% dos clones do Leito) contêm bacilos Gramnegativos estritamente anaeróbios. Segundo Pierre Juteau et al. (2005), Cryptanaerobacter phenolicus tem a habilidade de transformar fenol e 4hidroxibenzoato em benzoato. Portanto, a capacidade de metabolizar compostos aromáticos justifica sua presença no reator.

A família Syntrophomonadaceae ( $1 \%$ dos clones do Leito) são bactérias estritamente anaeróbias, formadora de endósporos que crescem em associação sintrófica com as arquéias metanogênicas (MATTHIES; SPRINGER; et al., 2000). Segundo os autores citados anteriormente, algumas espécies, tais como, Pelospora glutarica crescem unicamente na presença de glutamato, metilsuccinato e succinato. Os produtos da fermentação de glutarato e metilsuccinato são ácido butírico, ácido isobutírico e $\mathrm{CO}_{2}$, e o produto da fermentação do succinato é ácido propriônico. Nesse trabalho foram constatados $0,58 \mathrm{mg} / \mathrm{L}$ de ácido succínico no efluente da etapa IV, na qual foi retirada amostra de Biologia molecular. Tal fato, pode justificar a presença desse grupo microbiano no reator.

A família Synergistaceae foi relacionada a $24 \%$ dos clones da região do Copo e $30 \%$ dos clones da região do Leito. Nessa família foram observadas similaridade a Thermovirga, Cloacibacillus, Aminobacterium e Aminomonas .

Membros do gênero Thermovirga têm habilidade de formar agregados, apresentam mobilidade, Gram-negativos, não formadores de endósporos e crescem em condições anaeróbias. Algumas espécies têm sido isoladas de poços de petróleo (DAHLE \& BIRKELAND, 2006). Sabe-se que o LAS é derivado de hidrocarbonetos 
que é encontrado em grandes quantidades no petróleo, portanto, tal fato justifica a presença desse gênero no reator.

Os membros do gênero Cloabacillus são bacilos estritamente anaeróbios, sem mobilidade, Gram-negativos, não formam endósporos e fermentam a histidina, arginina, lisina, serina, e triptofano (GANESAN et al., 2008). Os membros do gênero Aminobacterium são bacilos curvos Gram-negativos, raramente formam cadeias, não apresentam mobilidade, não formam endósporos e fermentam serina, treonina e glicina (BAENA et al., 1999). A presença desses dois gêneros no reator EGSB deveu-se a carga protéica elevada no efluente de abatedouro de aves favorecendo a manutenção dessas bactérias no reator, mesmo com alteração da composição da água residuária diferente daquela usada no processamento de aves. Dessa forma, apesar de não estar diretamente ligados a degradação de compostos orgânicos, faziam parte da ampla diversidade de bactérias do inóculo proveniente do reator UASB usado no tratamento de água residuária de abatedouro de aves.

Aproximadamente, $4 \%$ do total de clones foram relacionados a ordem Clostridiales, família Incertae Sedis XI, XII e XIII com destaque para os gêneros Acidaminobacter, Parvimonas e Anaerovorax, respectivamente. O termo Incertae sedis "com posição incerta" é uma expressão latina utilizada na taxonomia para indicar o não estabelecimento da posição exata de um táxon. Tal possibilidade reflete a falta de acordo entre especialistas e/ou falta de informações.

O gênero Anaerovorax compreende bactérias estritamente anaeróbias, Grampositivas, não formadoras de endósporos, fermentam ácido acético, ácido butírico, e utilizam amônia (MATTHIES; EVERS; et al., 2000). Nesse trabalho foi constatada a presença de ácido acético e ácido butírico, na etapa IV, na qual foi retirada amostra de biologia molecular, corroborando com a necessidade metabólica desse gênero. A amônia, provavelmente, foi derivada do cloreto de amônio adicionado na alimentação do reator (Tabela 4.3).

Acidaminobacter são bacilos Gram-negativos com metabolismo fermentativo quimioorganotrófico e estritamente anaeróbios. Sua maior fonte de energia são os aminoácidos com formação de ácido acético (Stams \& Hansen 1984). Parvimonas são cocos Gram-positivos, não formadores de endósporos e estritamente anaeróbios (MURDOCHA \& H. N. SHAHB, 1999). Ambos os gêneros, provavelmente, vieram do inóculo e mantiveram-se no reator, mesmo após a mudança da composição da água residuária diferentemente daquela do reator UASB. 
Em relação a família Ruminococcaceae (2\% dos clones do Copo e $1 \%$ dos clones do leito) foi observada similaridade com Anaerotruncus. São bacilos Grampositivos, não formadores de endósporos e estritamente anaeróbios. Podem utilizar ácido isobutírico, isovalérico, málico, entre outros, para seu crescimento (LAWSON et al., 2004). O ácido málico não foi detectado durante as etapas de operação, todavia, ácido isobutírico e isovalérico foram detectados nas etapas III e IV, sendo, provavelmente, utilizados como substrato para os microrganismos desse gênero.

Portanto, a maior parte da microbiota identificada estava relacionada com as condições de operação do reator, seja com suas características físicas ou químicas, tais como, composição nutricional, co-substratos, LAS e/ou diversidade atribuída ao lodo granulado proveniente de abatedouro de aves.

Com o intuito de analisar a cobertura dos clones obtidos em relação a diversidade presente em cada região do reator, foi elaborado curvas de rarefação distintas, ou seja, uma para a região do leito e outra para a região do copo. Os resultados obtidos das UTOs com diferentes porcentagens de similaridade entre as seqüências $(100 \%, 97 \%$ e $90 \%)$, para os clones da região do copo e leito estão apresentadas nas Figura 5.18 e Figura 5.19, respectivamente.

Embora, essa análise evidencie a cobertura das sequiências obtidas em relação à diversidade microbiana presente nas regiões do reator, deve-se levar em conta as limitações da metodologia empregada. Dessa forma, a curva de rarefação é apenas um indicativo da representatividade da diversidade presente no reator.

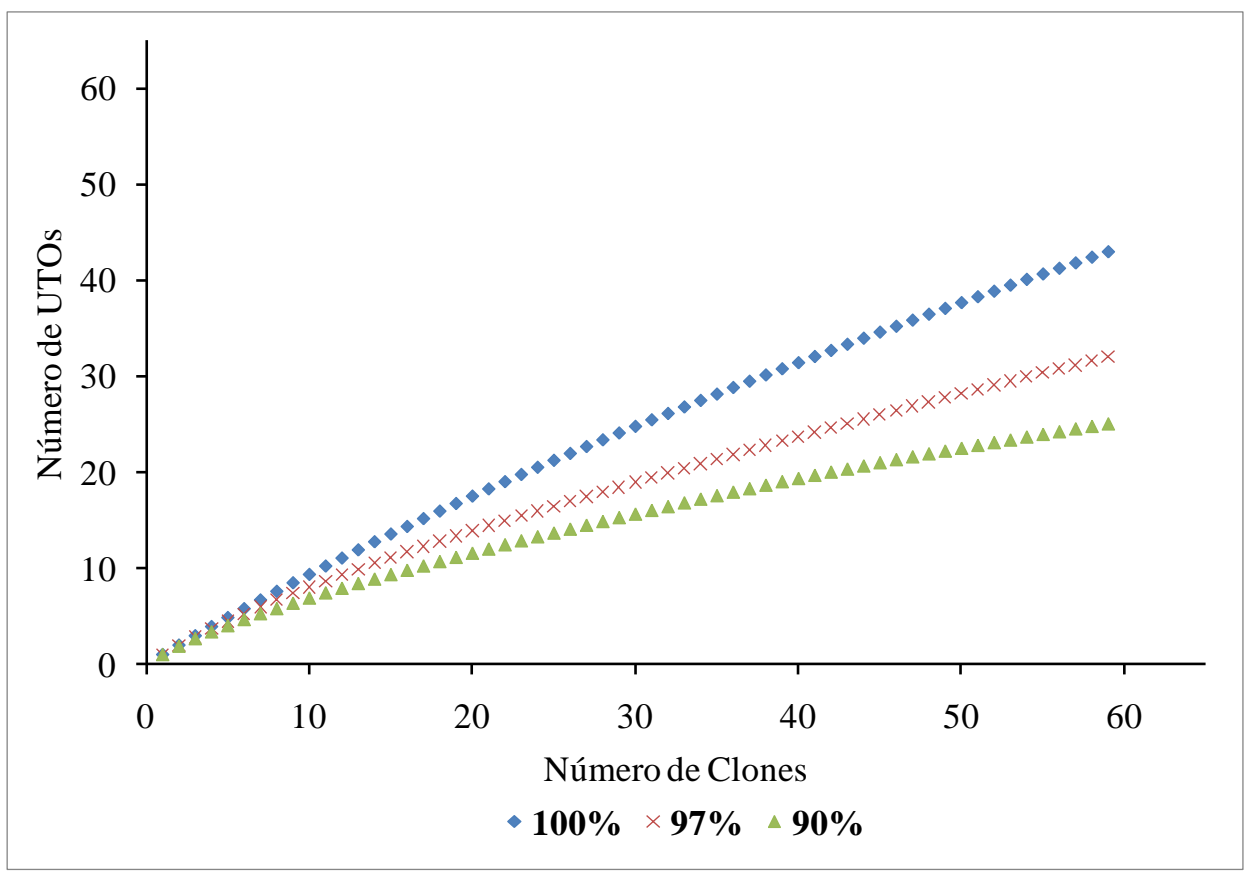

Figura 5.18: Curva de rarefação dos clones da região do copo do reator 


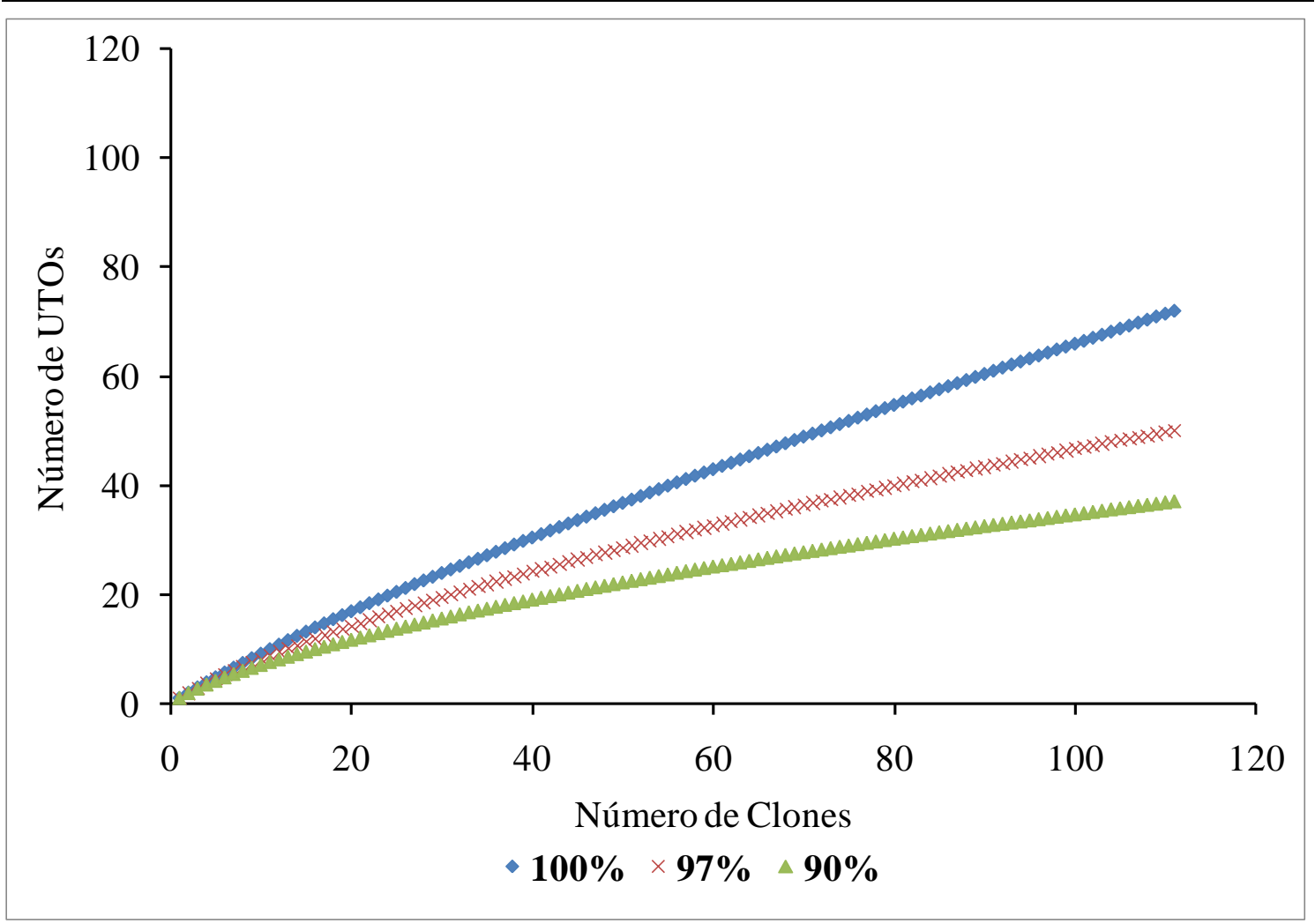

Figura 5.19: Curva de rarefação dos clones do leito do reator.

Para elaboração das árvores filogenéticas unificadas, as seqüências do copo (59) e leito (111) foram agrupadas em 40 unidades taxonômicas operacionais (UTOs), com distância evolutiva de 0,03. Os clones foram agrupados em várias UTOs (Tabela 5.16). Foram elaboradas quatro árvores filogenéticas dividas nos seguintes filos: Firmicutes (Figura 5.20), Proteobacteria (Figura 5.21), Synergistetes e Verrumicrobia (Figura 5.22) e, filo OP10, Actinobacteria, Acidobacteria, Chloroflexi e Bacteroidetes (Figura 5.23). 
Tabela 5.16: Números de UTOs e clones considerando distância evolutiva de 0,03. (C) clones do COPO e (L) clones do LEITO.

\begin{tabular}{|c|c|c|c|}
\hline UTO & CLONES & UTO & CLONES \\
\hline 1 & $\mathrm{C} 1$ & 21 & L108 \\
\hline 2 & $\mathrm{C} 17$ & 22 & L123 \\
\hline 3 & $\mathrm{C} 18$ & 23 & L27 \\
\hline 4 & $\mathrm{C} 20$ & 24 & L30 \\
\hline 5 & $\mathrm{C} 21$ & 25 & L42 \\
\hline 6 & C23, C25, L33, L72, L5, L13, L7, L65 & 26 & L48 \\
\hline 7 & $\mathrm{C} 27$ & 27 & L59 \\
\hline 8 & $\mathrm{C} 29$ & 28 & L69 \\
\hline 9 & C3, L36, L31 & 29 & L77 \\
\hline 10 & C32, C30, C39 & 30 & L81 \\
\hline 11 & C34, L2, L71 & 31 & $\mathrm{C} 4, \mathrm{C} 11$ \\
\hline 12 & $\mathrm{C} 40$ & 32 & L104,C41 \\
\hline 13 & C47 & 33 & $\mathrm{~L} 49, \mathrm{C} 22$ \\
\hline 14 & C49 & 34 & L79,L114 \\
\hline 15 & $\begin{array}{l}\text { C51, C56, C58, C28, C59, C6, C8, C61, C19, C45, C15, } \\
\text { C2, C36, C42, C12, C48, C13, C16, C46, C5, C7, C24 }\end{array}$ & 35 & $\mathrm{~L} 87, \mathrm{C} 10$ \\
\hline 16 & C62 & 36 & L9,C60 \\
\hline 17 & L1 & 37 & L38,L115 \\
\hline 18 & L103 & 38 & L15,L100,L53, \\
\hline 19 & $\begin{array}{c}\text { L106, L80, L120, L46, L50, L98, L17, L26, C33, C43, } \\
\text { L45,L61,L95,L105,L112,L122, } \\
\text { L32,L73,L35,L101,L124,L70,L116, } \\
\text { L34,L39,L40,L41,L66,L78,L85,L97,L125,L55,L74,L62 } \\
\text { L109,L54,L99, L63, L14, L23,L24 }\end{array}$ & 39 & L44,L86,L75,L83,C14 \\
\hline 20 & L107, L8, L84, L88, L119 & 40 & $\begin{array}{c}\text { L6, L16, L47, L52, } \\
\text { C55,L12,L89,L91,C50,L90,C } \\
\text { 31,C52,L28,L37,L43,L56,L5 } \\
\text { 8,L93, } \\
\text { C54, C35, } \\
\text { L64,L82,C9,C57,L51,L117 }\end{array}$ \\
\hline
\end{tabular}




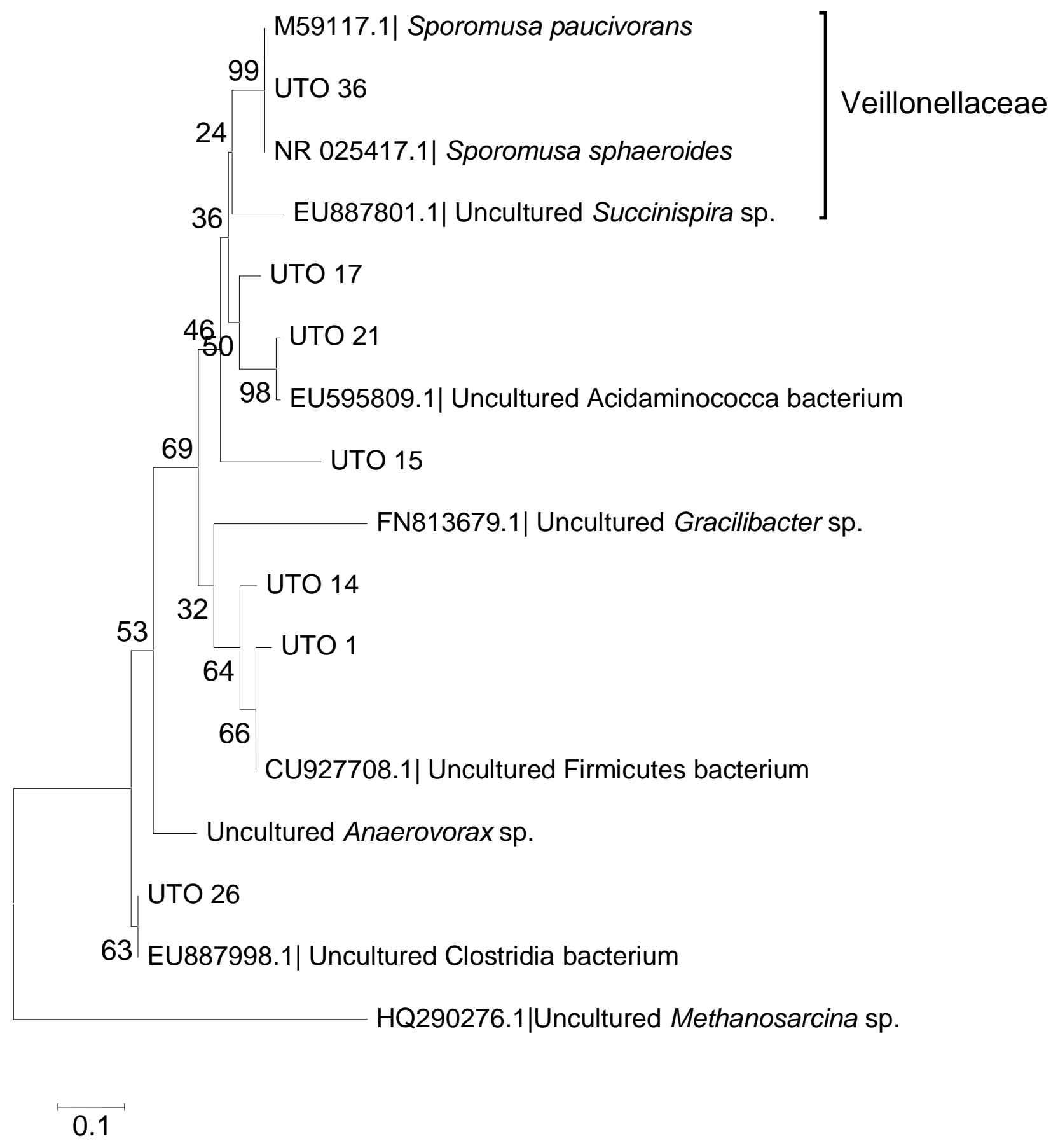

Figura 5.20 Árvore filogenética dos clones relacionados ao filo Firmicutes. A barra de escala informa a distância filogenética e Methanosarcina sp. foi escolhida como outgroup. 


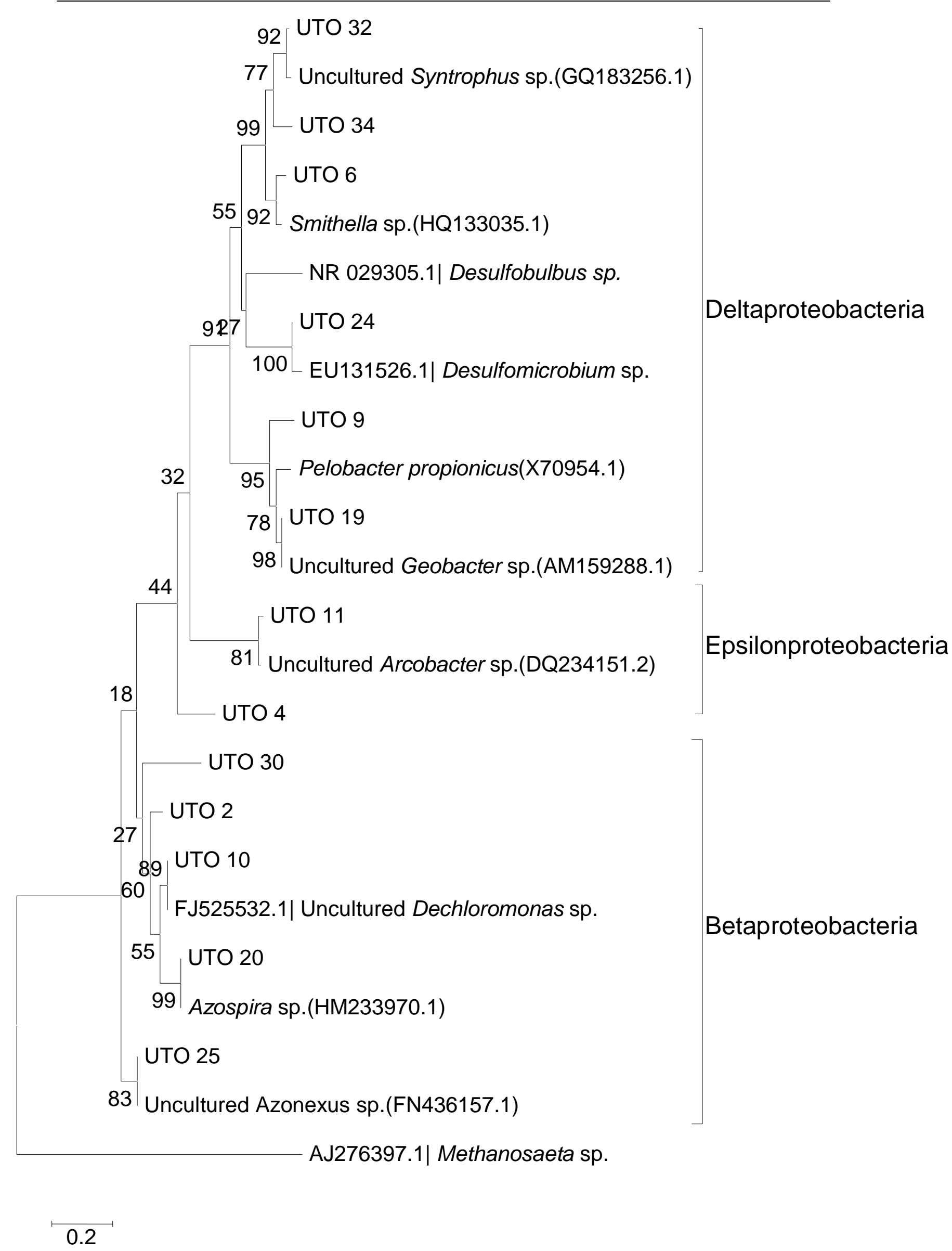

Figura 5.21: Árvore filogenética dos clones relacionados ao filo Protebacteria. A barra de escala informa a distância filogenética e Methanosaeta sp. foi escolhida como outgroup. 


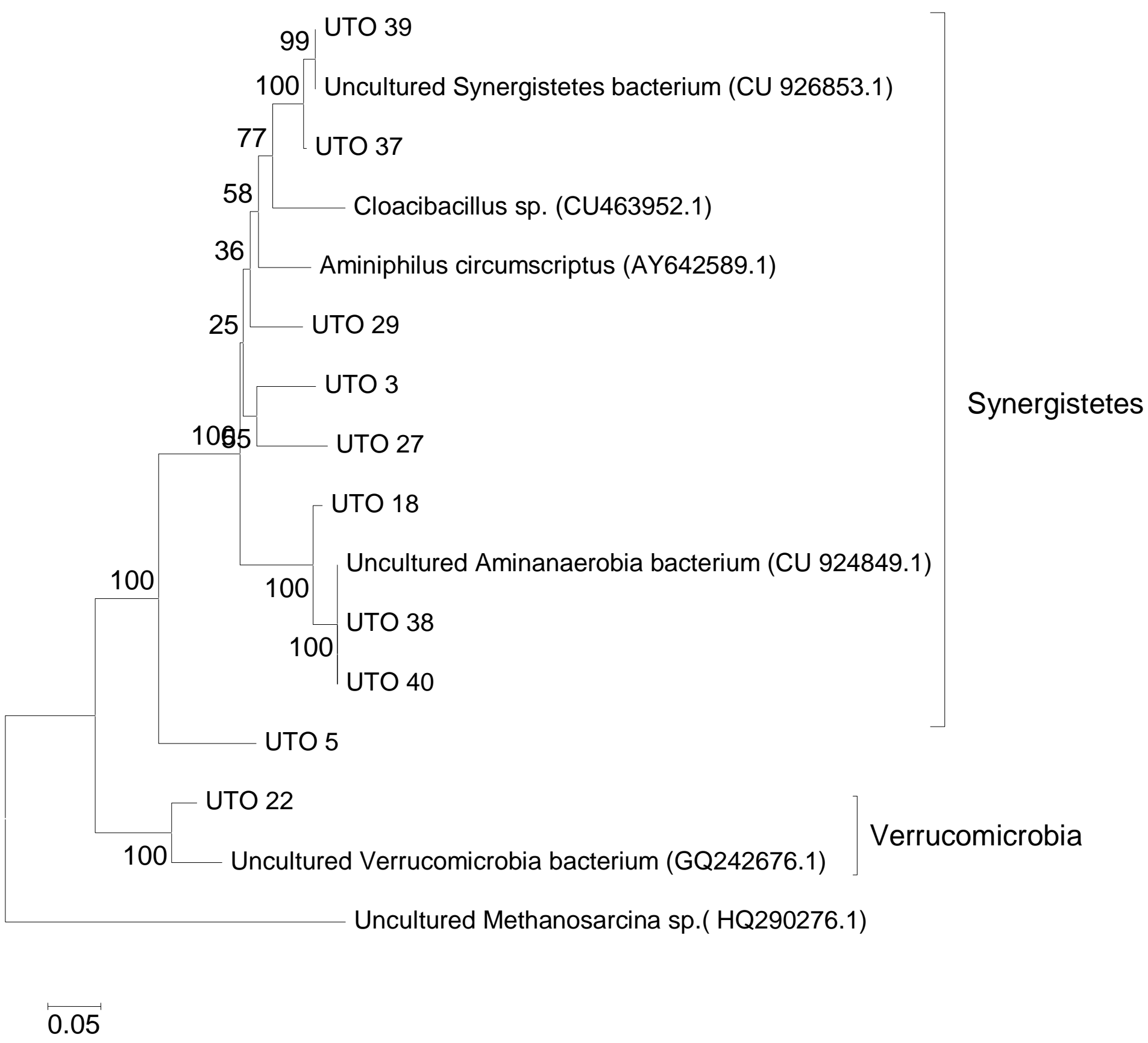

Figura 5.22: Árvore filogenética dos clones relacionados ao filo Synergistetes e Verrucomicrobia. A barra de escala informa a distância filogenética e Methanosarcina sp. foi escolhida como outgroup. 


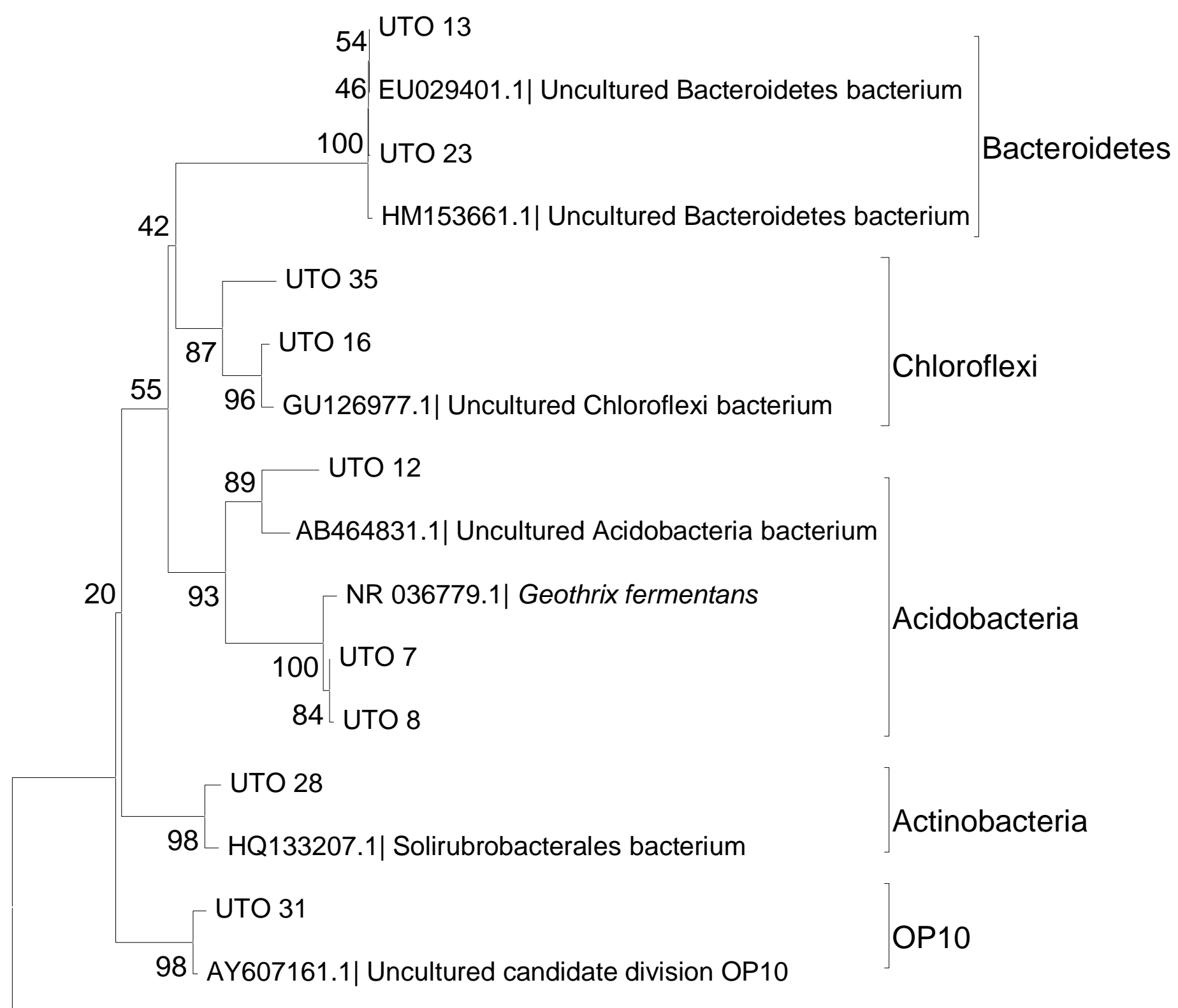

HQ290276.1| Uncultured Methanosarcina sp.

\section{1}

Figura 5.23: Árvore filogenética dos clones relacionados ao filo OP10, Actinobacteria, Acidobacteria, Chloroflexi e Bacteroidetes. A barra de escala informa a distância filogenética e Methanosarcina sp. foi escolhida como outgroup 


\subsubsection{Considerações Finais sobre a Biologia Molecular}

Como detalhado anteriormente, a molécula de LAS é sintetizada a partir de subprodutos de petróleo, apresenta na sua estrutura uma cadeia carbônica extensa (região hidrofóbica) e um anel aromático ligado ao grupo sulfonado (região hidrofílica).

$\mathrm{O}$ seqüenciamento da região $16 \mathrm{~S}$ do RNAr para o Domínio Bacteria permitiu identificar clones semelhantes a 7 Filos distintos, dos quais podemos destacar alguns gêneros que estão relacionadas com a degradação de compostos aromáticos e ou subprodutos de petróleo e, possivelmente estavam envolvidos com a remoção do LAS.

Na família Geobacteraceae (2\% dos clones do Copo e $25 \%$ dos clones do Leito) e Holophagaceae (4\% dos clones do Copo e ausentes no Leito) em especial os gêneros, Geobacter e Geotrix, respectivamente. Na família Desulfuromonadaceae em especial o gênero Pelobacter (4\% dos clones do Copo e 9\% do Leito). Na família Veillonellaceae (43\% dos clones do Copo e 3\% dos clones do Leito), com destaque para o gênero Sporomusa. Na família Rhodocyclaceae (7\% dos clones Copo e 7\% do Leito) em especial o gênero Dechloromonas. Na família Peptococcaceae (1\% dos clones do Leito) gênero Cryptanaerobacter. Na família Synergistaceae (24\% dos clones do Copo e 30\% dos clones do Leito) em especial o gênero Thermovirga.

Os demais gêneros identificados embora não estejam relacionados diretamente com a remoção de compostos aromáticos são importantes para manutenção do consorcio microbiana e dos processos biológicos envolvidos com a digestão anaeróbia. 


\section{CONCLUSÃO}

O reator EGSB foi eficiente na remoção do LAS. A melhor remoção foi no TDH de 32 horas. A remoção de DQO não foi prejudicada pela adição do surfactante. Características hidráulicas, tais como, TDH, diluição do afluente em função da recirculação e transferência de massa foram aspectos positivos que foram diretamente relacionados com a remoção do surfactante.

A recuperação do reator pode ser observada na Etapa IV, no qual, houve a retomada da remoção de LAS para valores acima de 63\%. Tal fato indicou a plasticidade da biomassa após uma condição com carga de LAS mais elevada.

Balanço de massa global apontou remoção de $57 \%$, sendo $8 \%$ devido à adsorção. A adsorção na biomassa efluente e biomassa do leito foram de $3 \%$ e $5 \%$, respectivamente.

Diminuição do diâmetro médio em função da longa exposição ao LAS foi observada, assim como, aumento de ácidos orgânicos voláteis. Foram detectadas concentrações significativas de bactérias redutoras de ferro, bactérias anaeróbias totais e arquéias metanogênicas pela técnica dos tubos múltiplos (NMP).

Instabilidade da biomassa ao surfactante ficou evidente quando da sua adição, uma vez que aumentou a concentração de sólidos totais efluente.

A microbiota estabelecida em função da alimentação, características hidráulicas do reator e inóculo empregado foram relacionadas com a remoção de compostos aromáticos. Em especial microrganismos redutores de ferro (Geobacter e Geotrix), e outros, tais como, Dechoromonas sp., Pelobacter sp. e Sporomusa sp. que possivelmente contribuíram para a degradação do LAS. As demais bactérias e arquéias metanogênicas desempenharam função importante na estabilidade do reator; justificando a importância do consórcio microbiano na remoção de compostos recalcitrantes. 


\section{SUGESTÕES PARA TRABALHOS FUTUROS}

- Estudar a partir da técnica SIP-DNA os microrganismos diretamente envolvidos com a degradação do LAS.

- Avaliar a remoção de LAS em função de diferentes aceptores finais de elétrons.

- Analisar a eficiência de remoção de LAS no reator EGSB com TDH menor. 


\section{REFERÊNCIAS BIBLIOGRÁFICAS}

ABBOUD, M. M.; KHEIFAT, K. M.; BATARSEH, M.; TARAWNEH, K. A.; ALMUSTAFA, A.; AL-MADADHAH, M. Different optimization conditions required for enhancing the biodegradation of linear alkylbenzosulfonate and sodium dodecyl sulfate surfactants by novel consortium of acinetobacter calcoaceticus and pantoea agglomerans. Enzyme and Microbial Technology, v. 41, n. 4, Sep, p. 432-439, 2007.

ALMENDARIZ, F. J.; MERAZ, M.; SOBERON, G.; MONROY, O. Degradation of lineal alkylbenzene sulphonate (las) in an acidogenic reactor bioaugmented with a pseudomonas aeruginosa (m113) strain. Water Science and Technology, v. 44, n. 4, p. 183-188, 2001.

ALPHENAAR, P. A.; VISSER, A.; LETTINGA, G. The effect of liquid upward velocity and hydraulic retention time on granulation in uasb reactors treating wastewater with a high sulfate content. Bioresource Technology, v. 43, n. 3, p. 249-258, 1993.

ANGELIDAKI, I.; PETERSEN, S. P.; AHRING, B. K. Effects of lipids on thermophilic anaerobic-digestion and reduction of lipid inhibition upon addition of bentonite. Applied Microbiology and Biotechnology, v. 33, n. 4, p. 469-472, 1990.

APHA; AWWA; WPCF. Standard methods for the examination of water and wastewater. 21. ed. Washington, DC: American Public Health Association, 2005

BAENA, S.; FARDEAU, M. L.; OLLIVIER, B.; LABAT, M.; THOMAS, P.; GARCIA, J. L.; PATEL, B. K. C. Aminomonas paucivorans gen. Nov., sp nov., a mesophilic anaerobic, amino-acid-utilizing bacterium. International Journal of Systematic Bacteriology, v. 49, p. 975-982, 1999.

BANAT, I. M.; MAKKAR, R. S.; CAMEOTRA, S. S. Potential commercial applications of microbial surfactants. Applied Microbiology and Biotechnology, v. 53, n. 5, p. 495-508, 2000.

BERNA, J. L.; FERRER, J.; MORENO, A.; PRATS, D.; BEVIA, F. R. The fate of las in the environment. Tenside Surfactants Detergents, v. 26, p. 101-107, 1989.

BUHL, K. J.; HAMILTON, S. J. Acute toxicity of fire-control chemicals, nitrogenous chemicals, and surfactants to rainbow trout. Transactions of the American Fisheries Society, v. 129, n. 2, p. 408-418, 2000.

CAMPOS, J. R. Tratamento de esgotos sanitários por processo anaeróbio e disposição controlada no solo Projeto PROSAB, p. 464, 1999.

CAVALLI, L.; GELLERA, A.; LANDONE, A. Las removal and biodegradation in a waste-water treatment-plant. Environmental Toxicology and Chemistry, v. 12, n. 10, p. 1777-1788, 1993. 
CHUN, J. Computer assisted classification and identification of actinomycetes. Ph.D. Thesis, University of Newcastle upon Tyne, Newcastle upon Tyne, UK, 1995.

COSTA, J. C.; ABREU, A. A.; FERREIRA, E. C.; ALVES, M. M. Quantitative image analysis as a diagnostic tool for monitoring structural changes of anaerobic granular sludge during detergent shock loads. Biotechnology and Bioengineering, v. 98, n. 1, Sep, p. 60-68, 2007.

DAHLE, H.; BIRKELAND, N. K. Thermovirga lienii gen. Nov., sp nov., a novel moderately thermophilic, anaerobic, amino-acid-degrading bacterium isolated from a north sea oil well. International Journal of Systematic and Evolutionary Microbiology, v. 56, p. 1539-1545, 2006.

DAVIDOVA, I. A.; DUNCAN, K. E.; CHOI, O. K.; SUFLITA, J. M. Desulfoglaeba alkanexedens gen. Nov., sp nov., an n-alkane-degrading, sulfate-reducing bacterium. International Journal of Systematic and Evolutionary Microbiology, v. 56, p. 27372742, 2006.

OLIVEIRA, L. L.; COSTA, R. B.; OKADA, D. Y.; VICH, D. V.; DUARTE, I. C. S.; SILVA, E. L.; VARESCHE, M. B. A. Anaerobic degradation of linear alkylbenzene sulfonate (las) in fluidized bed reactor by microbial consortia in different support materials. Bioresource Technology, v. 101, n. 14, p. 5112-5122, $2010 \mathrm{a}$.

OLIVEIRA, L. L.; DUARTE, I. C. S.; SAKAMOTO, I. K.; VARESCHE, M. B. A. Influence of support material on the immobilization of biomass for the degradation of linear alkylbenzene sulfonate in anaerobic reactors. Journal of Environmental Management, v. 90, n. 2, p. 1261-1268, 2009.

DENGER, K.; COOK, A. M. Assimilation of sulfur from alkyl- and arylsulfonates by clostridium spp. Archives of Microbiology, v. 167, n. 2-3, p. 177-181, 1997.

DILLALO, R., ALBERTSON, O.E. Volatile acids by direct tritation. Journal WPCF, v. 33, p. 356-365, 1961.

DUARTE, I. C. S.; OLIVEIRA, L. L.; BUZZINI, A. P.; ADORNO, M. A. T.; VARESCHE, M. B. A. Development of a method by hplc to determine las and its application in anaerobic reactors. Journal of the Brazilian Chemical Society, v. 17, n. 7, Nov-Dec, p. 1360-1367, 2006.

DUARTE, I. C. S.; OLIVEIRA, L. L.; MAYOR, M. S.; OKADA, D. Y.; VARESCHE, M. B. A. Degradation of detergent (linear alkylbenzene sulfonate) in an anaerobic stirred sequencing-batch reactor containing granular biomass. International Biodeterioration \& Biodegradation, v. 64, n. 2, Mar, p. 129-134, 2010.

DUARTE, I. C. S.; OLIVEIRA, L. L.; SAAVEDRA, N. K. D.; FANTINATTIGARBOGGINI, F.; OLIVEIRA, V. M.; VARESCHE, M. B. A. Evaluation of the microbial diversity in a horizontal-flow anaerobic immobilized biomass reactor treating linear alkylbenzene sulfonate. Biodegradation, v. 19, n. 3, Jun, p. 375-385, 2008. 
GANESAN, A.; CHAUSSONNERIE, S.; TARRADE, A.; DAUGA, C.; BOUCHEZ, T.; PELLETIER, E.; LE PASLIER, D.; SGHIR, A. Cloacibacillus evryensis gen. Nov., sp nov., a novel asaccharolytic, mesophilic, amino-acid-degrading bacterium within the phylum 'synergistetes', isolated from an anaerobic sludge digester. International Journal of Systematic and Evolutionary Microbiology, v. 58, p. 2003-2012, 2008.

GARCIA, M. T.; CAMPOS, E.; RIBOSA, I.; LATORRE, A.; SANCHEZ-LEAL, J. Anaerobic digestion of linear alkyl benzene sulfonates: Biodegradation kinetics and metabolite analysis. Chemosphere, v. 60, n. 11, Sep, p. 1636-1643, 2005.

GARCIA, M. T.; CAMPOS, E.; SANCHEZ-LEAL, J.; RIBOSA, I. Effect of linear alkylbenzene sulphonates (las) on the anaerobic digestion of sewage sludge. Water Research, v. 40, n. 15, p. 2958-2964, 2006.

GAVALA, H. N.; AHRING, B. K. Inhibition of the anaerobic digestion process by linear alkylbenzene sulfonates. Biodegradation, v. 13, n. 3, p. 201-209, 2002.

GONZALEZ-GIL, G.; LENS, P. N. L.; VAN AELST, A.; VAN AS, H.; VERSPRILLE, A. I.; LETTINGA, G. Cluster structure of anaerobic aggregates of an expanded granular sludge bed reactor. Applied and Environmental Microbiology, v. 67, n. 8, p. 3683-3692, 2001.

GOUDAR, C.; STREVETT, K.; GREGO, J. Competitive substrate biodegradation during surfactant-enhanced remediation. Journal of Environmental Engineering-Asce, v. 125, n. 12, p. 1142-1148, 1999.

GOULD, L. A.; LANSLEY, A. B.; BROWN, M. B.; FORBES, B.; MARTIN, G. P. Mitigation of surfactant erythrocyte toxicity by egg phosphatidylcholine. Journal of Pharmacy and Pharmacology, v. 52, n. 10, p. 1203-1209, 2000.

GRIFFITHS, R. I.; WHITELEY, A. S.; O'DONNELL, A. G.; BAILEY, M. J. Rapid method for coextraction of DNA and rna from natural environments for analysis of ribosomal DNA- and rrna-based microbial community composition. Applied and Environmental Microbiology, v. 66, n. 12, p. 5488-5491, 2000.

GUJER, W.; ZEHNDER, A. J. B. Conversion processes in anaerobic digestion. Wat. Sci. Technol., v. 15, p. 127-167, 1983.

HARRIS, J. K.; KELLEY, S. T.; PACE, N. R. New perspective on uncultured bacterial phylogenetic division op11. Applied and Environmental Microbiology, v. 70, n. 2, p. 845-849, 2004.

HERA. Human and environmental risk assesment on ingredients of european household cleaning products-linear alkylbenzene sulphonate, las - linear alkylbenzene sulphonate. Http://www.Heraproject.Com, acesso em 01 jan. 2011.

HOUF, K.; ON, S. L. W.; COENYE, T.; MAST, J.; VAN HOOF, J.; VANDAMME, P. Arcobacter cibarius sp nov., isolated from broiler carcasses. International Journal of Systematic and Evolutionary Microbiology, v. 55, p. 713-717, 2005. 
HUANG, C.; VANBENSCHOTEN, J. E.; HEALY, T. C.; RYAN, M. E. Feasibility study of surfactant use for remediation of organic and metal contaminated soils. Journal of Soil Contamination, v. 6, n. 5, p. 537-556, 1997.

HUSER, B. A.; WUHRMANN, K.; ZEHNDER, A. J. B. Methanothrix-soehngenii gennov-sp-nov, a new acetotrophic non-hydrogen-oxidizing methane bacterium. Archives of Microbiology, v. 132, n. 1, p. 1-9, 1982.

IGLESIASJIMENEZ, E.; POVEDA, E.; SANCHEZMARTIN, M. J.; SANCHEZCAMAZANO, M. Effect of the nature of exogenous organic matter on pesticide sorption by the soil. Archives of Environmental Contamination and Toxicology, v. 33, n. 2, p. 117-124, 1997.

JETTEN, M. S. M.; STAMS, A. J. M.; ZEHNDER, A. J. B. Methanogenesis from acetate: A comparison of the acetate metabolism in methanothrix soehngenii and methanosarcina spp. . FEMS Microbiology Letters, v. 88, n. 3-4, 1991.

JUMAS-BILAK, E.; ROUDIERE, L.; MARCHANDIN, H. Description of 'synergistetes' phyl. Nov and emended description of the phylum 'deferribacteres' and of the family syntrophomonadaceae, phylum 'firmicutes'. International Journal of Systematic and Evolutionary Microbiology, v. 59, p. 1028-1035, 2009.

KATO, M. T.; FIELD, J. A.; VERSTEEG, P.; LETTINGA, G. Feasibility of expanded granular sludge bed reactors for the anaerobic treatment of low-strength soluble wastewaters. Biotechnology and Bioengineering, v. 44, n. 4, p. 469-479, 1994.

KERTESZ, M. A.; KOLBENER, P.; STOCKINGER, H.; BEIL, S.; COOK, A. M. Desulfonation of linear alkylbenzenesulfonate surfactants and related-compounds by bacteria. Applied and Environmental Microbiology, v. 60, n. 7, p. 2296-2303, 1994.

LANE, D. J. 16s/23s rrna sequencing. Nucleic acid techniques in bacterial systematics. Stackebrandt and M. Goodfellow, eds. New York, p. 115-175, 1991.

LAWSON, P. A.; SONG, Y.; LIU, C.; MOLITORIS, D. R.; VAISANEN, M. L.; COLLINS, M. D.; FINEGOLD, S. M. Anaerotruncus colihominis gen. Nov., sp. Nov., from human faeces Int J Syst Evol Microbiol v. 54, 2004.

LAZARO, C. Z.; HIRASAWA J. S.; VARESCHE M. B. A.; ADORNO M. A. T. Development of an hplc method for the analysis of eleven short chain organic acids in bioproduction of hydrogen. In: XII Congresso Latino-Americano de Cromatografia e Técnicas Relacionadas (COLACRO). Florianópolis, SC, Brazil., 2008.

LETTINGA, G.; VANVELSEN, A. F. M.; HOBMA, S. W.; DEZEEUW, W.; KLAPWIJK, A. Use of the upflow sludge blanket (usb) reactor concept for biological wastewater-treatment, especially for anaerobic treatment. Biotechnology and Bioengineering, v. 22, n. 4, p. 699-734, 1980.

LIU, Y. T.; BALKWILL, D. L.; ALDRICH, H. C.; DRAKE, G. R.; BOONE, D. R. Characterization of the anaerobic propioate-degrading syntrophs smithella propionica 
gen. Nov., sp. Nov. And syntrophobacter wolinii. International Journal of Systematic Bacteriology, v. 49, p. 545-556, 1999.

LOBNER, T.; TORANG, L.; BATSTONE, D. J.; SCHMIDT, J. E.; ANGELIDAKI, I. Effects of process stability on anaerobic biodegradation of las in uasb reactors. Biotechnology and Bioengineering, v. 89, n. 7, Mar, p. 759-765, 2005.

LOVLEY, D. R.; STOLZ, J. F.; NORD, G. L.; PHILlIPS, E. J. P. Anaerobic production of magnetite by a dissimilatory iron-reducing microorganism. Nature, v. 330, n. 6145, p. 252-254, 1987.

MACLEOD, F. A.; GUIOT, S. R.; COSTERTON, J. W. Layered structure of bacterial aggregates produced in an upflow anaerobic sludge bed and filter reactor. Applied and Environmental Microbiology, v. 56, n. 6, p. 1598-1607, 1990.

MATTHIES, C.; EVERS, S.; LUDWIG, W.; SCHINK, B. Anaerovorax odorimutans gen. Nov., sp nov., a putrescine-fermenting, strictly anaerobic bacterium. International Journal of Systematic and Evolutionary Microbiology, v. 50, p. 1591-1594, 2000.

MATTHIES, C.; SPRINGER, N.; LUDWIG, W.; SCHINK, B. Pelospora glutarica gen. Nov., sp nov., a glutarate-fermenting, strictly anaerobic, spore-forming bacterium. International Journal of Systematic and Evolutionary Microbiology, v. 50, p. 645-648, 2000.

MCCRADY, M. H. The numerical interpretation of fermentation-tube results. Journal of Infectious Diseases, v. 17, n. 1, p. 183-212, 1915.

MOGENSEN, A. S.; HAAGENSEN, F.; AHRING, B. K. Anaerobic degradation of linear alkylbenzene sulfonate. Environmental Toxicology and Chemistry, v. 22, n. 4, p. 706-711, 2003.

MORAES, E. M.; ADORNO, M. A. T.; ZAIAT, M.; FORESTI, E. Determinação de ácidos voláteis por cromatografia gasosa em efluentes de reatores anaeróbios tratando resíduos líquidos e sólidos. In: VI Oficina e seminário latino-americano de digestão anaeróbia. Recife, PE: UFPE, 2000. p. 2813-2823.

MOSCHE, M.; MEYER, U. Toxicity of linear alkylbenzene sulfonate in anaerobic digestion: Influence of exposure time. Water Research, v. 36, n. 13, Jul, p. 3253-3260, 2002.

MURAMOTO, S.; OKI, Y.; NISHIZAKI, H.; AOYAMA, I. Variation in some element contents of water hyacinth due to cadmium or nickel treatment with or without anionic surface-active agents. Journal of Environmental Science and Health Part aEnvironmental Science and Engineering \& Toxic and Hazardous Substance Control, v. 24, n. 8, p. 925-934, 1989.

MURDOCHA, D. A.; H. N. SHAHB. Reclassification of peptostreptococcus magnus (prevot 1933) holdeman and moore 1972 as finegoldia magna comb. Nov. And peptostreptococcus micros(prevot1933) smith 1957 as micromonas micros comb. Nov Anaerobe, v. 5, n. 5, p. 555-559 1999. 
NUNEZ, L. A.; MARTINEZ, B. Anaerobic treatment of slaughterhouse wastewater in an expanded granular sludge bed (egsb) reactor. Water Science and Technology, v. 40, n. 8, p. 99-106, 1999.

OLIVEIRA, L. L. Remoção de alquibenzeno sulfonado (las) e caracterização microbiana em reator anaeróbio de leito fluidificado. . Tese (Doutorado) - Escola de Engenharia de São Carlos, Universidade de São Paulo, São Carlos, 2010., p. 176, 2010.

OLIVEIRA, L. L.; DUARTE, I. C. S.; SAKAMOTO, I. K.; VARESCHE, M. B. A. Influence of support material on the immobilization of biomass for the degradation of linear alkylbenzene sulfonate in anaerobic reactors. Journal of Environmental Management, v. 90, n. 2, Feb, p. 1261-1268, 2009.

PAINTER, H. A.; ZABEL, T. The behavior of las in sewage treatment. Tenside Surfactants Detergents, v. 26, p. 108-115, 1989.

PARK, J. W.; JAFFE, P. R. Partitioning of 3 nonionic organic-compounds between adsorbed surfactants, micelles, and water. Environmental Science \& Technology, v. 27, n. 12 , p. 2559-2565, 1993.

PENTEADO, J. C. P.; SEOUD, O. A. E.; CARVALHO, L. R. F. Linear alkylbenzene sulfonates: Chemistry, environmental impact and analysis. Quimica Nova, v. 29, n. 5, Sep-Oct, p. 1038-1046, 2006.

RAJPUT, V. S.; HIGGINS, A. J.; SINGLEY, M. E. Cleaning of excavated soil contaminated with hazardous organic-compounds by washing. Water Environment Research, v. 66, n. 6, p. 819-827, 1994.

RAZO-FLORES, E.; SVITELSKAYA, A.; DONLON, B.; FIELD, J.; LETTINGA, G. The effect of granular sludge source on the anaerobic biodegradability of aromatic compounds Bioresource Technology, v. 56, p. 215-220, 1996.

RIPLEY, L. E.; BOYLE, W. C.; CONVERSE, J. C. Improved alkalimetric monitoring for anaerobic-digestion of high-strength wastes. Journal Water Pollution Control Federation, v. 58, n. 5, p. 406-411, 1986.

RODEN, E. E.; URRUTIA, M. M.; MANN, C. J. Bacterial reductive dissolution of crystalline fe(iii) oxide in continuous-flow column reactors. Applied and Environmental Microbiology, v. 66, n. 3, p. 1062-1065, 2000.

RUFFO, C.; FEDRIGUCCI, M. G.; VALTORTA, L.; CAVALLI, L. Biodegradation of anionic and non-ionic surfactants by $\mathrm{co} 2$ evolution. Acclimated and non-acclimated inoculum. Riv. It. Sostanze Grasse, p. 277-283, 1999.

SAKAMOTO, I. S. Comportamento do consórcio microbiano existente em um lodo granulado anaeróbio metanogênico submetido a adições crescentes de sulfato. . Dissertação de mestrado, EESC, USP, São Carlos, , 1996. 
SANZ, J. L.; CULUBRET, E.; DE FERRER, J.; MORENO, A.; BERNA, J. L. Anaerobic biodegradation of linear alkylbenzene sulfonate (las) in upflow anaerobic sludge blanket (uasb) reactors. Biodegradation, v. 14, n. 1, p. 57-64, 2003.

SCHOBERL, P. Linear alkylbenzene sulfonate (las) - monitoring .2. Tenside Surfactants Detergents, v. 32, n. 1, Jan-Feb, p. 25-35, 1995.

SCOTT, M. J.; JONES, M. N. The biodegradation of surfactants in the environment. Biochimica Et Biophysica Acta-Biomembranes, v. 1508, n. 1-2, Nov, p. 235-251, 2000.

SEGHEZZO, L.; ZEEMAN, G.; VAN LIER, J. B.; HAMELERS, H. V. M.; LETTINGA, G. A review: The anaerobic treatment of sewage in uasb and egsb reactors. Bioresource Technology, v. 65, n. 3, p. 175-190, 1998.

SINGH, R. P.; RAWAT, J. P.; KUMAR, R. Effect of cationic, non-ionic and anionic surfactants on the adsorption of carbofuran on three different types of indian soil. Adsorption Science \& Technology, v. 18, n. 4, p. 333-346, 2000.

STAMS, A. J. M.; HANSEN, T. A. Fermentation of glutamate and other compounds by acidaminobacter-hydrogenoformans gen-nov sp-nov, an obligate anaerobe isolated from black mud - studies with pure cultures and mixed cultures with sulfate-reducing and methanogenic bacteria. Archives of Microbiology, v. 137, n. 4, p. 329-337, 1984.

TAN, H.; CHAMPION, J. T.; ARTIOLA, J. F.; BRUSSEAU, M. L.; MILLER, R. M. Complexation of cadmium by a rhamnolipid biosurfactant. Environmental Science \& Technology, v. 28, n. 13, p. 2402-2406, 1994.

TOUZEL, J. P.; ALBAGNAC, G. Isolation and characterization of methanococcusmazei strain mc3. FEMS Microbiology Letters, v. 16, n. 2-3, p. 241-245, 1983.

VAZOLLER, R. F. Avaliação do ecossistema microbiano de um biodigestor anaeróbio de fluxo ascendente e manta de lodo, operado com vinhaça sob condições termofílicas. Tese de doutorado. EESC, USP, São Carlos, 1995.

VENHUIS, S. H.; MEHRVAR, M. Health effects, environmental impacts, and photochemical degradation of selected surfactants in water. International Journal of Photoenergy, v. 6, n. 3, p. 115-125, 2004.

VERGE, C.; MORENO, A.; BRAVO, J.; BERNA, J. L. Influence of water hardness on the bioavailability and toxicity of linear alkylbenzene sulphonate (las). Chemosphere, v. 44, n. 8, p. 1749-1757, 2001.

WAGENER, S.; SCHINK, B. Anaerobic degradation of nonionic and anionic surfactants in enrichment cultures and fixed-bed reactors. Water Research, v. 21, n. 5, p. 615-622, 1987.

YAMADA, T.; SEKIGUCHI, Y.; HANADA, S.; IMACHI, H.; OHASHI, A.; HARADA, H.; KAMAGATA, Y. Anaerolinea thermolimosa sp nov., levilinea saccharolytica gen. Nov., sp nov and leptolinea tardivitalis gen. Nov., so. Nov., novel filamentous anaerobes, and description of the new classes anaerolineae classis nov and 
caldilineae classis nov in the bacterial phylum chloroflexi. International Journal of Systematic and Evolutionary Microbiology, v. 56, p. 1331-1340, 2006.

YING, G.-G. Fate, behavior and effects of surfactants and their degradation products in the environment. Environment International v. 32 p. $417-431$

2006.

ZHILINA, T. N. Death of methanosarcina in the air. Microbiology (Engl. Transl.), v. 41, p. 980-981, 1972. 
9 APÊNDICES

\section{SIMILARIDADE DOS CLONES*}

Tabela A1: Similaridade dos clones da região do leito usando a ferramenta RDP classifier*

\begin{tabular}{|c|c|c|c|c|c|}
\hline \multirow{2}{*}{$\begin{array}{c}\text { Clones } \\
\text { L69 } \\
\end{array}$} & \multirow{2}{*}{$\begin{array}{c}\text { Filo } \\
\text { Actinobacteria } \\
\end{array}$} & \multicolumn{2}{|l|}{ Família } & \multicolumn{2}{|l|}{ Gênero } \\
\hline & & Solirubrobacterales & $23 \%$ & Conexibacteraceae & $20 \%$ \\
\hline L87 & Chloroflexi & Anaerolineaceae & $36 \%$ & Bellilinea & $17 \%$ \\
\hline $\mathrm{L} 27$ & Bacteroidetes & Flavobacteriaceae & $100 \%$ & Cloacibacterium & $99 \%$ \\
\hline L81 & Proteobacteria & Comamonadaceae & $60 \%$ & Alicycliphilus & $55 \%$ \\
\hline L2 & Proteobacteria & Campylobacteraceae & $100 \%$ & Arcobacter & $100 \%$ \\
\hline L32 & Proteobacteria & Campylobacteraceae & $100 \%$ & Arcobacter & $100 \%$ \\
\hline L35 & Proteobacteria & Campylobacteraceae & $100 \%$ & Arcobacter & $100 \%$ \\
\hline L70 & Proteobacteria & Campylobacteraceae & $100 \%$ & Arcobacter & $100 \%$ \\
\hline L71 & Proteobacteria & Campylobacteraceae & $48 \%$ & Arcobacter & $48 \%$ \\
\hline L73 & Proteobacteria & Campylobacteraceae & $100 \%$ & Arcobacter & $100 \%$ \\
\hline L101 & Proteobacteria & Campylobacteraceae & $100 \%$ & Arcobacter & $100 \%$ \\
\hline L116 & Proteobacteria & Campylobacteraceae & $100 \%$ & Arcobacter & $100 \%$ \\
\hline L124 & Proteobacteria & Campylobacteraceae & $100 \%$ & Arcobacter & $100 \%$ \\
\hline $\mathrm{L} 42$ & Proteobacteria & Rhodocyclaceae & $98 \%$ & Azonexus & $84 \%$ \\
\hline L8 & Proteobacteria & Rhodocyclaceae & $100 \%$ & Azospira & $100 \%$ \\
\hline L84 & Proteobacteria & Rhodocyclaceae & $96 \%$ & Azospira & $95 \%$ \\
\hline L88 & Proteobacteria & Rhodocyclaceae & $100 \%$ & Azospira & $100 \%$ \\
\hline L107 & Proteobacteria & Rhodocyclaceae & $100 \%$ & Azospira & $97 \%$ \\
\hline L119 & Proteobacteria & Rhodocyclaceae & $100 \%$ & Azospira & $100 \%$ \\
\hline L18 & Proteobacteria & Desulfobulbaceae & $100 \%$ & Desulfobulbus & $100 \%$ \\
\hline L30 & Proteobacteria & Desulfomicrobiaceae & $100 \%$ & Desulfomicrobium & $100 \%$ \\
\hline
\end{tabular}




\begin{tabular}{|c|c|c|c|c|c|}
\hline L14 & Proteobacteria & Geobacteraceae & $79 \%$ & Geobacter & $78 \%$ \\
\hline L23 & Proteobacteria & Geobacteraceae & $100 \%$ & Geobacter & $100 \%$ \\
\hline $\mathrm{L} 24$ & Proteobacteria & Geobacteraceae & $100 \%$ & Geobacter & $100 \%$ \\
\hline $\mathrm{L} 26$ & Proteobacteria & Geobacteraceae & $52 \%$ & Geobacter & $52 \%$ \\
\hline L34 & Proteobacteria & Geobacteraceae & $72 \%$ & Geobacter & $72 \%$ \\
\hline L39 & Proteobacteria & Geobacteraceae & $67 \%$ & Geobacter & $66 \%$ \\
\hline $\mathrm{L} 40$ & Proteobacteria & Geobacteraceae & $66 \%$ & Geobacter & $66 \%$ \\
\hline $\mathrm{L} 41$ & Proteobacteria & Geobacteraceae & $83 \%$ & Geobacter & $83 \%$ \\
\hline $\mathrm{L} 45$ & Proteobacteria & Geobacteraceae & $60 \%$ & Geobacter & $60 \%$ \\
\hline $\mathrm{L} 46$ & Proteobacteria & Geobacteraceae & $72 \%$ & Geobacter & $72 \%$ \\
\hline L54 & Proteobacteria & Geobacteraceae & $77 \%$ & Geobacter & $77 \%$ \\
\hline L55 & Proteobacteria & Geobacteraceae & $81 \%$ & Geobacter & $81 \%$ \\
\hline L61 & Proteobacteria & Geobacteraceae & $96 \%$ & Geobacter & $96 \%$ \\
\hline L62 & Proteobacteria & Geobacteraceae & $69 \%$ & Geobacter & $69 \%$ \\
\hline L63 & Proteobacteria & Geobacteraceae & $92 \%$ & Geobacter & $92 \%$ \\
\hline L66 & Proteobacteria & Geobacteraceae & $73 \%$ & Geobacter & $73 \%$ \\
\hline $\mathrm{L} 74$ & Proteobacteria & Geobacteraceae & $85 \%$ & Geobacter & $84 \%$ \\
\hline $\mathrm{L} 78$ & Proteobacteria & Geobacteraceae & $80 \%$ & Geobacter & $80 \%$ \\
\hline L85 & Proteobacteria & Geobacteraceae & $81 \%$ & Geobacter & $81 \%$ \\
\hline L95 & Proteobacteria & Geobacteraceae & $62 \%$ & Geobacter & $62 \%$ \\
\hline L97 & Proteobacteria & Geobacteraceae & $79 \%$ & Geobacter & $79 \%$ \\
\hline L98 & Proteobacteria & Geobacteraceae & $72 \%$ & Geobacter & $72 \%$ \\
\hline L105 & Proteobacteria & Geobacteraceae & $71 \%$ & Geobacter & $71 \%$ \\
\hline L109 & Proteobacteria & Geobacteraceae & $70 \%$ & Geobacter & $70 \%$ \\
\hline L112 & Proteobacteria & Geobacteraceae & $87 \%$ & Geobacter & $87 \%$ \\
\hline L122 & Proteobacteria & Geobacteraceae & $61 \%$ & Geobacter & $61 \%$ \\
\hline L125 & Proteobacteria & Geobacteraceae & $78 \%$ & Geobacter & $78 \%$ \\
\hline
\end{tabular}




\begin{tabular}{|c|c|c|c|c|c|}
\hline L106 & Proteobacteria & Geobacteraceae & $16 \%$ & Geothermobacter & $10 \%$ \\
\hline L17 & Proteobacteria & Desulfuromonadaceae & $60 \%$ & Pelobacter & $60 \%$ \\
\hline L31 & Proteobacteria & Desulfuromonadaceae & $65 \%$ & Pelobacter & $65 \%$ \\
\hline L36 & Proteobacteria & Desulfuromonadaceae & $76 \%$ & Pelobacter & $75 \%$ \\
\hline $\mathrm{L} 50$ & Proteobacteria & Desulfuromonadaceae & $55 \%$ & Pelobacter & $49 \%$ \\
\hline L80 & Proteobacteria & Desulfuromonadaceae & $54 \%$ & Pelobacter & $54 \%$ \\
\hline L99 & Proteobacteria & Desulfuromonadaceae & $51 \%$ & Pelobacter & $51 \%$ \\
\hline L120 & Proteobacteria & Desulfuromonadaceae & $51 \%$ & Pelobacter & $51 \%$ \\
\hline L79 & Proteobacteria & Syntrophaceae & $99 \%$ & Syntrophus & $76 \%$ \\
\hline L104 & Proteobacteria & Syntrophaceae & $100 \%$ & Syntrophus & $75 \%$ \\
\hline L114 & Proteobacteria & Syntrophaceae & $97 \%$ & Syntrophus & $64 \%$ \\
\hline L5 & Proteobacteria & Syntrophaceae & $39 \%$ & Smithella & $31 \%$ \\
\hline $\mathrm{L} 7$ & Proteobacteria & Syntrophaceae & $64 \%$ & Smithella & $52 \%$ \\
\hline L13 & Proteobacteria & Syntrophaceae & $80 \%$ & Smithella & $67 \%$ \\
\hline L33 & Proteobacteria & Syntrophaceae & $100 \%$ & Smithella & $93 \%$ \\
\hline $\mathrm{L} 72$ & Proteobacteria & Syntrophaceae & $58 \%$ & Smithella & $35 \%$ \\
\hline $\mathrm{L} 25$ & Proteobacteria & Rhodocyclaceae & $93 \%$ & Zoogloea & $87 \%$ \\
\hline L65 & Proteobacteria & Syntrophaceae & $38 \%$ & Smithella & $34 \%$ \\
\hline L49 & Firmicutes & Ruminococcaceae & $35 \%$ & Anaerotruncus & $15 \%$ \\
\hline $\mathrm{L} 48$ & Firmicutes & Incertae Sedis XIII & $98 \%$ & Anaerovorax & $98 \%$ \\
\hline L9 & Firmicutes & Syntrophomonadaceae & $25 \%$ & Pelospora & $20 \%$ \\
\hline L1 & Firmicutes & Peptococcaceae & $19 \%$ & Peptococcaceae 1 & $18 \%$ \\
\hline L10 & Firmicutes & Veillonellaceae & $22 \%$ & Succinispira & $13 \%$ \\
\hline L108 & Firmicutes & Veillonellaceae & $98 \%$ & Zymophilus & $12 \%$ \\
\hline L29 & Firmicutes & Veillonellaceae & $22 \%$ & Succinispira & $14 \%$ \\
\hline $\mathrm{L} 21$ & Synergistetes & Synergistaceae & $100 \%$ & Cloacibacillus & $95 \%$ \\
\hline L38 & Synergistetes & Synergistaceae & $100 \%$ & Cloacibacillus & $36 \%$ \\
\hline
\end{tabular}




\begin{tabular}{|c|c|c|c|c|c|}
\hline $\mathrm{L} 75$ & Synergistetes & Synergistaceae & $100 \%$ & Cloacibacillus & $34 \%$ \\
\hline L83 & Synergistetes & Synergistaceae & $99 \%$ & Cloacibacillus & $55 \%$ \\
\hline L86 & Synergistetes & Synergistaceae & $100 \%$ & Cloacibacillus & $38 \%$ \\
\hline L28 & Synergistetes & Synergistaceae & $79 \%$ & Aminiphilus & $34 \%$ \\
\hline L115 & Synergistetes & Synergistaceae & $96 \%$ & Aminiphilus & $43 \%$ \\
\hline L20 & Synergistetes & Synergistaceae & $99 \%$ & Aminobacterium & $67 \%$ \\
\hline $\mathrm{L} 44$ & Synergistetes & Synergistaceae & $58 \%$ & Aminobacterium & $30 \%$ \\
\hline L59 & Synergistetes & Synergistaceae & $98 \%$ & Aminobacterium & $86 \%$ \\
\hline L3 & Synergistetes & Synergistaceae & $100 \%$ & Aminomonas & $88 \%$ \\
\hline $\mathrm{L} 4$ & Synergistetes & Synergistaceae & $100 \%$ & Aminomonas & $89 \%$ \\
\hline L11 & Synergistetes & Synergistaceae & $100 \%$ & Aminomonas & $90 \%$ \\
\hline L19 & Synergistetes & Synergistaceae & $100 \%$ & Aminomonas & $92 \%$ \\
\hline L6 & Synergistetes & Synergistaceae & $70 \%$ & Thermovirga & $25 \%$ \\
\hline L12 & Synergistetes & Synergistaceae & $98 \%$ & Thermovirga & $44 \%$ \\
\hline L15 & Synergistetes & Synergistaceae & $87 \%$ & Thermovirga & $32 \%$ \\
\hline L16 & Synergistetes & Synergistaceae & $77 \%$ & Thermovirga & $28 \%$ \\
\hline L37 & Synergistetes & Synergistaceae & $95 \%$ & Thermovirga & $43 \%$ \\
\hline $\mathrm{L} 43$ & Synergistetes & Synergistaceae & $95 \%$ & Thermovirga & $69 \%$ \\
\hline $\mathrm{L} 47$ & Synergistetes & Synergistaceae & $97 \%$ & Thermovirga & $59 \%$ \\
\hline $\mathrm{L} 51$ & Synergistetes & Synergistaceae & $84 \%$ & Thermovirga & $58 \%$ \\
\hline L52 & Synergistetes & Synergistaceae & $94 \%$ & Thermovirga & $52 \%$ \\
\hline L53 & Synergistetes & Synergistaceae & $22 \%$ & Thermovirga & $14 \%$ \\
\hline L56 & Synergistetes & Synergistaceae & $95 \%$ & Thermovirga & $51 \%$ \\
\hline L58 & Synergistetes & Synergistaceae & $99 \%$ & Thermovirga & $54 \%$ \\
\hline L64 & Synergistetes & Synergistaceae & $98 \%$ & Thermovirga & $57 \%$ \\
\hline $\mathrm{L} 77$ & Synergistetes & Synergistaceae & $90 \%$ & Thermovirga & $52 \%$ \\
\hline L82 & Synergistetes & Synergistaceae & $93 \%$ & Thermovirga & $55 \%$ \\
\hline
\end{tabular}




\begin{tabular}{|c|c|c|c|c|c|}
\hline L89 & Synergistetes & Synergistaceae & $97 \%$ & Thermovirga & $54 \%$ \\
\hline L90 & Synergistetes & Synergistaceae & $91 \%$ & Thermovirga & $41 \%$ \\
\hline L91 & Synergistetes & Synergistaceae & $98 \%$ & Thermovirga & $46 \%$ \\
\hline L93 & Synergistetes & Synergistaceae & $94 \%$ & Thermovirga & $61 \%$ \\
\hline L96 & Synergistetes & Synergistaceae & $22 \%$ & Thermovirga & $14 \%$ \\
\hline L100 & Synergistetes & Synergistaceae & $88 \%$ & Thermovirga & $47 \%$ \\
\hline L103 & Synergistetes & Synergistaceae & $88 \%$ & Thermovirga & $50 \%$ \\
\hline L117 & Synergistetes & Synergistaceae & $92 \%$ & Thermovirga & $46 \%$ \\
\hline
\end{tabular}

*Os gêneros e filos foram determinados usando a ferramenta RDP classifier. A \% representa a probabilidade de acordo com o RDP classifier para limite de confiança de $95 \%$.

Tabela A2: Similaridade dos clones da região do copo usando a ferramenta RDP classifier* $^{*}$

\begin{tabular}{|c|c|c|c|c|c|}
\hline \multirow{2}{*}{$\begin{array}{c}\text { Clones } \\
\text { C27 }\end{array}$} & \multirow{2}{*}{$\begin{array}{c}\text { Filo } \\
\text { "Acidobacteria" }\end{array}$} & \multicolumn{2}{|l|}{ Família } & \multicolumn{2}{|l|}{ Gênero } \\
\hline & & Holophagaceae & $100 \%$ & Geothrix & $73 \%$ \\
\hline $\mathrm{C} 29$ & "Acidobacteria" & Holophagaceae & $100 \%$ & Geothrix & $69 \%$ \\
\hline $\mathrm{C} 40$ & "Acidobacteria" & Acanthopleuribacteraceae & $39 \%$ & Acanthopleuribacter & $39 \%$ \\
\hline $\mathrm{C} 10$ & "Chloroflexi" & Anaerolineaceae & $25 \%$ & Bellilinea & $20 \%$ \\
\hline C62 & "Chloroflexi" & Anaerolineaceae & $67 \%$ & Bellilinea & $36 \%$ \\
\hline $\mathrm{C} 47$ & "Bacteroidetes" & Flavobacteriaceae & $100 \%$ & Cloacibacterium & $99 \%$ \\
\hline $\mathrm{C} 4$ & OP10 & - & - & OP10_genera_incertae_sedis & $99 \%$ \\
\hline $\mathrm{C} 11$ & OP10 & - & - & OP10_genera_incertae_sedis & $99 \%$ \\
\hline $\mathrm{C} 20$ & "Proteobacteria" & Nautiliaceae & $20 \%$ & Lebetimonas & $16 \%$ \\
\hline $\mathrm{C} 30$ & "Proteobacteria" & Rhodocyclaceae & $100 \%$ & Dechloromonas & $70 \%$ \\
\hline $\mathrm{C} 32$ & "Proteobacteria" & Rhodocyclaceae & $100 \%$ & Dechloromonas & $75 \%$ \\
\hline C39 & "Proteobacteria" & Rhodocyclaceae & $100 \%$ & Dechloromonas & $92 \%$ \\
\hline $\mathrm{C} 33$ & "Proteobacteria" & Geobacteraceae & $69 \%$ & Geobacter & $69 \%$ \\
\hline $\mathrm{C} 43$ & "Proteobacteria" & Geobacteraceae & $57 \%$ & Geobacter & $57 \%$ \\
\hline
\end{tabular}




\begin{tabular}{|c|c|c|c|c|c|}
\hline $\mathrm{C} 34$ & "Proteobacteria" & Campylobacteraceae & $90 \%$ & Arcobacter & $90 \%$ \\
\hline $\mathrm{C} 17$ & "Proteobacteria" & Rhodocyclaceae & $100 \%$ & Azonexus & $85 \%$ \\
\hline $\mathrm{C} 3$ & "Proteobacteria" & Desulfuromonadaceae & $51 \%$ & Pelobacter & $51 \%$ \\
\hline $\mathrm{C} 23$ & "Proteobacteria" & Syntrophaceae & $43 \%$ & Smithella & $32 \%$ \\
\hline $\mathrm{C} 41$ & "Proteobacteria" & Syntrophaceae & $98 \%$ & Syntrophus & $55 \%$ \\
\hline $\mathrm{C} 25$ & "Proteobacteria" & Syntrophaceae & $92 \%$ & Smithella & $79 \%$ \\
\hline C60 & "Firmicutes" & "Gracilibacteraceae" & $21 \%$ & Gracilibacter & $21 \%$ \\
\hline $\mathrm{C} 1$ & "Firmicutes" & "Ruminococcaceae" & $43 \%$ & Anaerotruncus & $19 \%$ \\
\hline $\mathrm{C} 49$ & "Firmicutes" & "Ruminococcaceae" & $30 \%$ & Anaerotruncus & $17 \%$ \\
\hline $\mathrm{C} 2$ & "Firmicutes" & Veillonellaceae & $100 \%$ & Sporomusa & $100 \%$ \\
\hline $\mathrm{C} 5$ & "Firmicutes" & Veillonellaceae & $100 \%$ & Sporomusa & $100 \%$ \\
\hline C6 & "Firmicutes" & Veillonellaceae & $100 \%$ & Sporomusa & $100 \%$ \\
\hline $\mathrm{C} 7$ & "Firmicutes" & Veillonellaceae & $100 \%$ & Sporomusa & $100 \%$ \\
\hline $\mathrm{C} 8$ & "Firmicutes" & Veillonellaceae & $100 \%$ & Sporomusa & $100 \%$ \\
\hline $\mathrm{C} 12$ & "Firmicutes" & Veillonellaceae & $100 \%$ & Sporomusa & $100 \%$ \\
\hline $\mathrm{C} 13$ & "Firmicutes" & Veillonellaceae & $100 \%$ & Sporomusa & $100 \%$ \\
\hline $\mathrm{C} 15$ & "Firmicutes" & Veillonellaceae & $100 \%$ & Sporomusa & $100 \%$ \\
\hline $\mathrm{C} 16$ & "Firmicutes" & Veillonellaceae & $100 \%$ & Sporomusa & $100 \%$ \\
\hline $\mathrm{C} 19$ & "Firmicutes" & Veillonellaceae & $100 \%$ & Sporomusa & $100 \%$ \\
\hline $\mathrm{C} 24$ & "Firmicutes" & Veillonellaceae & $100 \%$ & Sporomusa & $100 \%$ \\
\hline $\mathrm{C} 28$ & "Firmicutes" & Veillonellaceae & $100 \%$ & Sporomusa & $100 \%$ \\
\hline $\mathrm{C} 36$ & "Firmicutes" & Veillonellaceae & $100 \%$ & Sporomusa & $100 \%$ \\
\hline $\mathrm{C} 42$ & "Firmicutes" & Veillonellaceae & $100 \%$ & Sporomusa & $100 \%$ \\
\hline $\mathrm{C} 45$ & "Firmicutes" & Veillonellaceae & $100 \%$ & Sporomusa & $100 \%$ \\
\hline $\mathrm{C} 46$ & "Firmicutes" & Veillonellaceae & $100 \%$ & Sporomusa & $100 \%$ \\
\hline $\mathrm{C} 48$ & "Firmicutes" & Veillonellaceae & $100 \%$ & Sporomusa & $100 \%$ \\
\hline $\mathrm{C} 51$ & "Firmicutes" & Veillonellaceae & $85 \%$ & Sporomusa & $56 \%$ \\
\hline C56 & "Firmicutes" & Veillonellaceae & $97 \%$ & Sporomusa & $97 \%$ \\
\hline $\mathrm{C} 58$ & "Firmicutes" & Veillonellaceae & $95 \%$ & Sporomusa & $90 \%$ \\
\hline
\end{tabular}




\begin{tabular}{c|c|c|c|c}
\hline & & & & \\
C59 & "Firmicutes" & Veillonellaceae & $100 \%$ & Sporomusa \\
\hline C61 & "Firmicutes" & Veillonellaceae & $100 \%$ & Sporomusa \\
\hline C26 & "Firmicutes" & Veillonellaceae & $16 \%$ & Succinispira \\
\hline C38 & "Firmicutes" & Veillonellaceae & $21 \%$ & $13 \%$ \\
\hline C18 & "Synergistetes" & Synergistaceae & $100 \%$ & Succinispira \\
\hline C14 & "Synergistetes" & Synergistaceae & $100 \%$ & Cloacibacillus \\
\hline C9 & "Synergistetes" & Synergistaceae & $90 \%$ & $38 \%$ \\
\hline C21 & "Synergistetes" & Synergistaceae & $63 \%$ & Thermovirga \\
\hline C22 & "Synergistetes" & Synergistaceae & $17 \%$ & Thermovirga \\
\hline C31 & "Synergistetes" & Synergistaceae & $97 \%$ & Thermovirga \\
\hline C35 & "Synergistetes" & Synergistaceae & $99 \%$ & Thermovirga \\
\hline C50 & "Synergistetes" & Synergistaceae & $97 \%$ & Thermovirga \\
\hline C52 & "Synergistetes" & Synergistaceae & $89 \%$ & Thermovirga \\
\hline C54 & "Synergistetes" & Synergistaceae & $93 \%$ & Thermovirga \\
\hline C55 & "Synergistetes" & Synergistaceae & $90 \%$ & Thermovirga \\
\hline C57 & "Synergistetes" & Synergistaceae & $95 \%$ & Thermovirga \\
\hline OS
\end{tabular}

*Os gêneros e filos foram determinados usando a ferramenta RDP classifier. A \% representa a probabilidade de acordo com o RDP classifier para limite de confiança de $95 \%$. 
